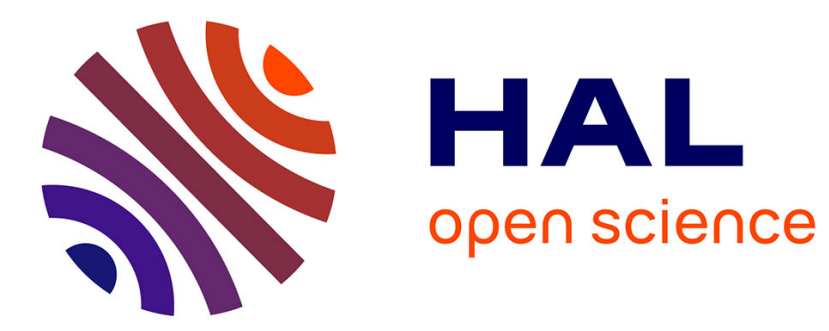

\title{
Trade barriers in government procurement
}

Alen Mulabdic, Lorenzo Rotunno

\section{To cite this version:}

Alen Mulabdic, Lorenzo Rotunno. Trade barriers in government procurement. 2021. halshs-03191482

\section{HAL Id: halshs-03191482 \\ https://shs.hal.science/halshs-03191482}

Preprint submitted on 7 Apr 2021

HAL is a multi-disciplinary open access archive for the deposit and dissemination of scientific research documents, whether they are published or not. The documents may come from teaching and research institutions in France or abroad, or from public or private research centers.
L'archive ouverte pluridisciplinaire HAL, est destinée au dépôt et à la diffusion de documents scientifiques de niveau recherche, publiés ou non, émanant des établissements d'enseignement et de recherche français ou étrangers, des laboratoires publics ou privés. 


\section{amse}

école d'économie d'aix-marseille aix-marseille school of economics

\section{Working Papers / Documents de travail}

\section{Trade barriers in government procurement}




\title{
Trade barriers in government procurement*
}

\author{
Alen Mulabdic ${ }^{\dagger}$ \\ Lorenzo Rotunno $\ddagger$
}

April 2021

\begin{abstract}
This paper estimates trade barriers in government procurement, a market that accounts for $12 \%$ of world GDP. Using data from inter-country input-output tables in a gravity model, we find that home bias in government procurement is significantly higher than in trade between firms. However, this difference has been shrinking over time. Results also show that trade agreements with provisions on government procurement increase cross-border flows of services, whereas the effect on goods is small and not different from that in private markets. Provisions containing transparency and procedural requirements drive the liberalizing effect of trade agreements.
\end{abstract}

Keywords: Government Procurement, Trade Agreements, Gravity Equation.

JEL codes: F13, F14, F15, H57.

\footnotetext{
${ }^{*}$ We are grateful to Mario Larch and Federico Trionfetti for insightful exchanges and suggestions. We also thank Serena Cocciolo, Julien Gourdon, Asif Islam, Bill Maloney, Gustavo Piga, and participants to the World Bank Virtual Seminar Series on Deep Trade Agreements for useful comments. This paper is part of World Bank's ongoing work on Deep Trade Agreements and a background paper for the flagship report on Global Public Procurement and Development Impact. This paper has benefited from support from the World Bank's Umbrella Facility for Trade trust fund financed by the governments of the Netherlands, Norway, Sweden, Switzerland and the United Kingdom. Lorenzo Rotunno acknowledges funding received from the French National Research Agency Grants ANR-17-EURE-0020. Errors are our responsibility only. The findings, interpretations, and conclusions expressed in this paper are entirely those of the authors. They do not necessarily represent the views of the International Bank for Reconstruction and Development/World Bank and its affiliated organizations, or those of the Executive Directors of the World Bank or the governments they represent.

${ }^{\dagger}$ World Bank, 1818 H Street, Washington DC, USA. Email: amulabdic@worldbank.org.

${ }^{\ddagger}$ Aix-Marseille Univ., CNRS, EHESS, Centrale Marseille, IRD, AMSE, Marseille, France. Email: lorenzo.rotunno@univ-amu.fr
} 


\section{Introduction}

Government procurement is a major market, accounting for about $12 \%$ of world GDP in 2018 (Bosio et al., 2020). Given this important size, public authorities often prefer local to foreign providers in procurement contracts in order to achieve socioeconomic objectives (e.g., promoting "sustainable" local purchases, and the development of small and medium local enterprises). ${ }^{1}$ Buy-national provisions are prime examples of measures that explicitly exclude foreign firms from government contracts. The Global Trade Alert (GTA) initiative has collected data since 2009 on the adoption of protectionist measures in government procurement. The data show that 56 new discriminatory measures in government procurement were enacted on average each year between 2009 and $2018 .^{2}$

In parallel with this persistent protectionism, governments have committed to greater market access in government procurement through the WTO Government Procurement Agreement (GPA) as well as targeted provisions within other free trade agreements (TAs). Membership to the WTO GPA expanded from the initial 34 signatory countries (including EU member states) in 1996 to a group of 48 as of 2020. Meanwhile, the number of TAs including enforceable provisions aimed at liberalizing procurement markets has been increasing over time. Figure 1 shows that provisions on government procurement have become more common since 2000. In 2017, a quarter of TAs in force had enforceable provisions on government procurement.

\footnotetext{
${ }^{1}$ We use the terms "government", "public sector" and "public authorities" interchangeably to indicate public institutions that are buyers in the public procurement market.

${ }^{2}$ We include only policies that the GTA database classifies as "red" (i.e., that almost certainly discriminate against foreign firms) in the following policy areas: "Government Procurement: Domestic Price Preference", "Government Procurement: Local Content Requirement", "Government Procurement: Market Access Restrictions" and "Government Procurement: Tendering Process". These protectionist measures involve around 2500 country pairs (one country implementing the policy measure and the other being among the targets) per year.
} 
Figure 1: Number of TAs with and without enforceable provisions in government procurement

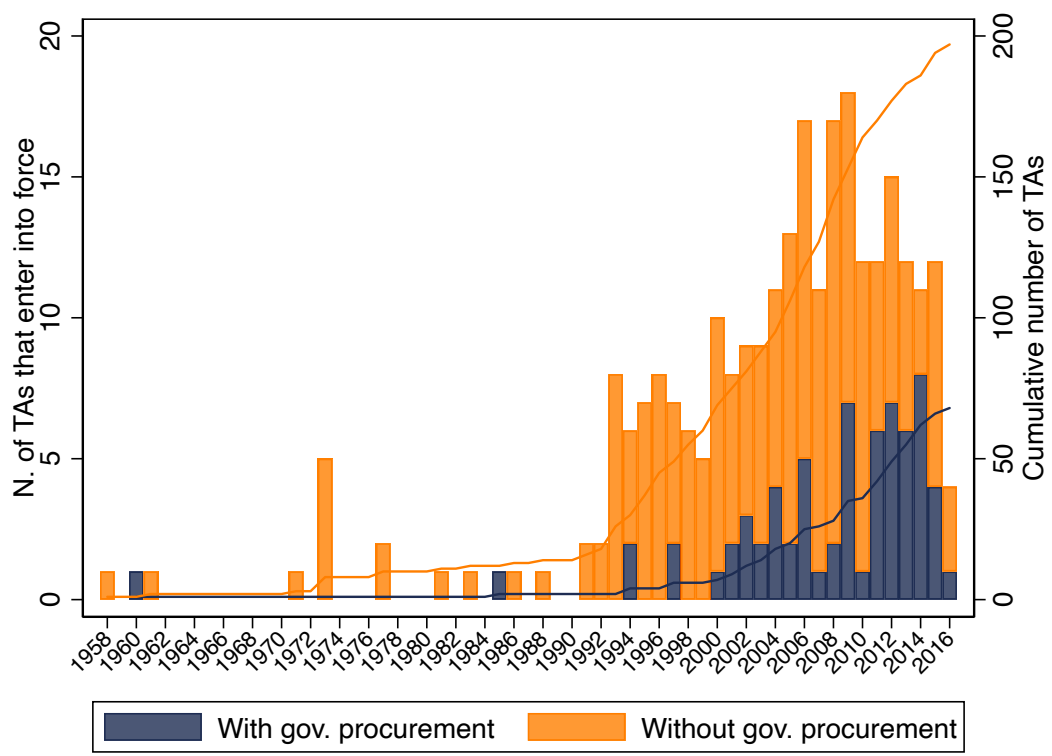

Note: Authors' calculations on the basis of the Deep Trade Agreements data from Mattoo et al. (2020). We exclude "Partial Scope Agreements".

Against this seemingly contradicting policy landscape (with unilateral discriminatory measures being adopted together with liberalizing ones), this paper aims to assess the importance of trade barriers in government procurement and identify the impact of trade agreements on cross-border flows. We employ data from the Trade in Value-Added (TiVA) database of the OECD on 62 countries between 1995 and 2015. Our preferred definition of purchases by the public sector sums the "General Government expenditures" and the "Public Administration", "Health" and "Education" output columns of the inter-country input-output (ICIO) tables. Bilateral trade values are distinguished by goods and services. Descriptive trends in the data show that the public sector spends considerably more on services than on goods compared to the private sector. What is more, the import share of expenditure in government procurement relative to the one in the rest of the economy is particularly low in services, although important heterogeneity emerges across countries.

To move beyond descriptive evidence and estimate trade barriers in government procurement, we apply a canonical gravity framework relating bilateral cross-border procurement flows to different variables proxying for trade costs (or their inverse) and multilateral resistance terms. We also apply the same gravity framework to bilateral trade in the rest of the economy - what we refer to as the private sector or market - which we use as a benchmark as well as a way to observe possible spillovers of procurement-specific 
policies. Gravity specifications without country-pair dummies allow us to identify the "border effect" introduced by McCallum (1995) - how much internal trade is larger than international trade - and subsequently estimated with different settings and techniques (Anderson and van Wincoop, 2003; Chen, 2004; de Sousa et al., 2012). This provides a first measure of trade barriers as it identifies the effect of crossing the border on domestic relative to international trade. Results show a large border effect in general, confirming the findings of the literature (de Sousa et al., 2012). Borders in government procurement are thicker than in private markets. The difference is significant and larger in services than in goods, confirming the descriptive evidence. While discrimination of foreign firms contributes to the large border effect in government procurement, other characteristics of procurement contracts unrelated to the nationality of the supplier (e.g., the existence of 'set-aside', differences in legal procedures across countries) might well inflate the value of domestic procurement contracts relative to that of contracts awarded to foreign firms.

Our preferred specifications control for bilateral fixed effects and hence permit better identification of the effects of trade policies (Baier and Bergstrand, 2007). We focus on provisions aimed at liberalizing government procurement that are included in TAs, while controlling for other TAs (most notably in our sample, EU membership) and membership in the WTO GPA. We find that specific provisions included in TAs distinctively increase cross-border government procurement in services relative to trade in services in the private sector. Our estimates suggest that cross-border procurement in services is 77 percent higher when two countries are part of a TA with provisions on procurement. This effect is reduced when we isolate the influence of EU membership, which takes up almost half of our sample. The results point to an important effect of EU entry on government imports of both manufacturing and services, suggesting that EU directives aimed at opening up public procurement markets have been instrumental in increasing public purchases of goods and services from abroad. According to our findings, trade in public markets between two countries is 40 (for goods) to 60 percent (for services) higher when both are EU members. As for the WTO GPA, we also find robust effects but only for cross-border government procurement in services. Since more than half of the GPA members are EU countries and many engage in 'deep' TAs with procurement provisions, the effects of the GPA and those of TAs might be confounded (Anderson et al., 2017).

In additional estimations, we find that the trade-creating effect of TAs is driven by 'unilateral' provisions - i.e., provisions for which it is difficult to exclude firms from 
non-member countries. Two pieces of evidence support this finding. First, we estimate the effect of each provision in separate gravity models. While the clustering of provisions makes the interpretation of the findings purely suggestive, we find that measures aimed at fostering transparency and sharing of information (e.g., possibility of e-procurement, availability of statistics on government procurement) have the largest impact on bilateral trade. Second, we single out these provisions that are clearly unilateral (transparency and procedural matters) in a country-specific measure of 'depth' of TAs. Results from an extended gravity model (see, e.g., Heid et al. (2021); Beverelli et al. (2018)) show that the border effect in government procurement for services is significantly lower in countries with higher unilateral depth of TAs. Participation in TAs with unilateral provisions increases cross-border procurement flows relative to domestic ones.

To examine further the tendency to buy national by public authorities, we estimate an index of "Constructed Home Bias" (CHB) in the public and private sectors (Anderson and Yotov, 2010b; Anderson et al., 2014). This measure is complementary to the border effect as it compares the amount of actual internal trade (as estimated by the gravity equation) relative to internal trade in a counterfactual frictionless trade scenario. Holding overall sales and expenditure fixed, trade barriers of different types around the world (and hence not only the national border) determine the size of the home bias index. Results confirm what anecdotal evidence suggests: home bias in government procurement is large and higher on average than in the private markets. The difference is less striking when we look at goods and services separately. This suggests that governments are more home-biased than the private sector because (i) they source more goods and services locally; and (ii) they spend more in sectors that are more home biased. Looking at variation over time, we find that the home bias in government procurement decreased for most countries in the sample over the 1995-2015 period, but important heterogeneity emerges. The developing countries in our sample including China, Vietnam and India experienced the largest declines in home bias, whereas government procurement has become more national in most developed economies, such as Japan, Germany and France. Developed countries are however the countries with the lowest levels of CHB.

The paper contributes to the relatively scant academic literature on government procurement in the context of international trade. Baldwin (1970) was the first to formally analyze the role of government expenditures in a traditional factor proportions model of international trade. His findings that discrimination in public expenditure is inconsequential 
for trade flows and specialization were revised and confirmed only partly in oligopolistic settings (Miyagiwa, 1991) and with imperfect information (McAfee and McMillan, 1989). ${ }^{3}$ Within general equilibrium models with increasing returns to scale, Brulhart and Trionfetti (2004) find that trade barriers in government expenditure can actually change the patterns of specialization, while Trionfetti (2001) identifies a significant impact of home-biased government procurement on agglomeration following trade liberalization. In all these papers, home bias in the public sector is treated as a parameter. Trionfetti (2000) provides a first attempt to quantify this home bias. He uses domestic input-output tables - which are part of the ICIO data - for seven European countries to compare import penetration ratios across public and private sectors. Rickard and Kono (2014) uses aggregate trade data in a gravity framework and find that countries with larger government procurement import less, thus suggesting public home bias. We extend this empirical strand of the literature by estimating trade barriers in government procurement directly, by using information from input-output tables, both in absolute terms and relative to the private sector. In doing so, we highlight the importance of the composition of government procurement - i.e., its bias towards services.

In this paper, we infer government procurement purchases from inter-country input-output tables in order to estimate the effect of TAs and their provisions on cross-border purchases. Related work has exploited contract-level data mainly for the U.S. and the EU to assess the local bias in public purchases. Using EU data, Herz and Varela-Irimia (2020) find large border effects both across and within European countries adopting a gravity-style estimation approach, and Kutlina-Dimitrova and Lakatos (2014) provide evidence indicating that product market regulation and policies on Foreign Direct investments (FDIs) affect the probability of awarding a procurement contract to a foreign firm. ${ }^{4}$ Fronk (2014) estimates the effect of TAs in a gravity model using U.S. federal procurement data - as such, he has one buyer (the U.S.) from multiple suppliers. While measuring precisely procurement purchases (at least by certain public entities and for values above certain thresholds) ${ }^{5}$, the contract-level data cover only a single or a few countries

\footnotetext{
${ }^{3}$ Cole et al. (2017) extends the model of McAfee and McMillan (1989) to establish an equivalence between price preferences in procurement auctions and import tariffs.

${ }^{4}$ Gourdon and Messent (2019) estimate the effect of TAs on the value of procurement contracts awarded by the EU on non-EU firms using both contract-level and aggregate data. Their set of TAs is thus limited to those signed by the EU.

5 The TED (Tenders Electronic Daily) database includes contracts awarded by public authorities (at the national and sub-national level) in countries of the European Economic Area and by EU institutions. Reporting is a requirement if the value of the contract is above a certain threshold (around 5 million euros
} 
(like in the case of the EU) and hence do not permit to investigate the effect of TAs and their provisions. We overcome this limitation by using instead inter-country input-output tables to measure government procurement flows. The drawback of this data source is that we do not observe procurement purchases directly, but we employ constructed data based on national accounts. The use of the empirically successful gravity model aims at filtering out noise and identify central tendency in the data. ${ }^{6}$

Our analysis draws extensively from the large literature on the gravity model of trade (Head and Mayer, 2015; Anderson, 2011) to assess the policy determinants of trade flows. In doing so, we do not attempt to develop a fully-fledged theoretical model that explains, for instance, the allocation of public and private expenditures across sectors. Our focus is on the incidence of trade policy, taking aggregate sales and expenditure as given. Owing to the separability between allocation of resources within and across countries that is common to many models of trade, we infer trade costs in a "conditional general equilibrium" setting (Anderson and van Wincoop, 2004), i.e. taking as given the allocations of resources across type of goods and services in the public and private sectors. As Fronk (2014) shows, a gravity-style empirical model can be derived also from the auction framework of McAfee and McMillan (1989) combined with a standard comparative advantage model à la Eaton and Kortum (2002). We rely on this validity of the gravity framework for analyzing bilateral flows in government procurement and estimating measures of home bias. Further, our work expands the literature on the partial equilibrium effects of trade agreements (Baier and Bergstrand, 2007; Bergstrand et al., 2015) and its provisions (Dür et al., 2014; Kohl et al., 2016; Mattoo et al., 2017) by focusing on trade where the public sector is the buyer. ${ }^{7}$ When we focus on specific TA provisions on government procurement, we rely on recent work showing how to identify the effect of unilateral trade policy within a structural gravity model (Heid et al., 2021; Sellner, 2019; Beverelli et al., 2018). We isolate provisions, like the pubic sharing of information and statistics, whose application is non-excludable (i.e., conditional on compliance by the member countries, non-member countries benefit as well

for construction, and 130 thousand euros for supplies and services). The U.S. Federal Procurement Data System collects contract award data for procurement contracts at the federal level only.

${ }^{6}$ Fajgelbaum and Khandelwal (2016) use similar data from the World Input-Output Database (WIOD) to estimate the parameters of a non-homothetic gravity equation.

${ }^{7}$ A theoretically-consistent estimate of the comparative statics effect of TAs requires to specify the full general equilibrium model because changes in trade costs generally affect the allocation of resources across sectors. Different assumptions on the underlying structure of the economy can lead to a common formulation of the comparative statics effect of a change in trade costs as reviewed by Costinot and Rodriguez-Clare (2015). Egger et al. (2011), for instance, estimate the full trade effect of TAs. 
from the content of the provision), and find that they significantly increase cross-border relative to national government procurement of services.

The rest of the paper proceeds as follows. In section 2, we briefly discuss the choice of the gravity equation as our empirical framework. In section 3, we describe the empirical specification and the data. Section 4 provides a descriptive analysis of trade data. Section

5 presents the results of the gravity estimations and the home bias indexes. In section 6 we conclude by discussing the policy implications of our results.

\section{Theoretical framework}

In this section, we present our theoretical framework, justify its choice, and describe how we bring it to the data.

We aim to define a simple framework that allows us to identify trade barriers in public procurement across countries. The gravity model can serve this purpose. It has been widely used to infer the determinants of bilateral trade and it is consistent with many general equilibrium models of trade (Head and Mayer, 2015). We argue that the gravity equation can be used also to explore the determinants of trade in government procurement. To show this, we work with the simplest theoretical framework that delivers a gravity equation: the one based on the national product differentiation assumption due to Armington $(1969)^{8}$, where each country is endowed with a differentiated variety of a type $k$ (in our empirical applications, $k$ corresponds to goods or services). As Anderson (1979) shows, this assumption coupled with CES preferences or technology delivers a gravity equation.

To better capture the procurement of goods and service, we consider shipments of intermediate inputs. The private and public market $s$ in each country $j$ sources inputs of type $k$ originated from country $i$. Crucially, varieties are differentiated by the type $s \in\{p, r\}$ of buyer, where $p$ stands for public and $r$ denotes private market. One way to think about this assumption is that firms are specialized in either the public or private market. ${ }^{9}$ Let

\footnotetext{
${ }^{8}$ The theoretical framework outlined here, being based on the gravity equation, can be derived from a number of assumptions on the demand and supply sides of the model (Head and Mayer, 2015). Ricardian comparative advantage models á la Eaton and Kortum (2002) and monopolistic competition models with Dixit-Stiglitz-type assumptions deliver a gravity equation. Larch and Lechthaler (2013), for instance, use a monopolistic competition framework to estimate the welfare maximizing share of domestic public procurement.

${ }^{9}$ Note that with an endogenous characterization of the supply side (e.g., in a monopolistic competition or
} 
$X_{i j}^{k, s}$ denote the value of shipments of good or service $k$ from country $i$ to market (public or private) $s$ of country $j$. Trade is subject to a variable cost factor $t_{i j}^{k, s}>1$ of iceberg type. Given factory gate prices of $p_{i}^{k, s}$, destination prices are $p_{i j}^{k, s} \equiv p_{i}^{k, s} t_{i j}^{k, s}$. Let $E_{j}^{k, s}$ denote public or private expenditure on good type $k$ in country $j$ and $Y_{i}^{k, s}$ the income that suppliers in $i$ derive from selling good $k$ to market $s$.

Governments choose their optimal demand for intermediate input $k$ from country $i$ in order to minimize costs subject to a CES technology, which, for simplicity, is assumed to be equal across public and private markets. The different varieties of intermediate inputs are thus assembled in a composite public good that is transferred to consumers. Consumers derive utility from this public good and a private good aggregate transferred by the private firms. ${ }^{10}$ Invoking the "trade separability" assumption (Anderson and van Wincoop, 2004), we require only that the allocation of resources across private and public goods can be separated from the allocation of income and expenditures within type $(k, s)$ across countries. ${ }^{11}$ Under this assumption, the government's problem can be partitioned solved in two steps. In a first step, the government chooses the level of aggregate expenditure and thus taxation that maximize household's utility (Larch and Lechthaler, 2013). In a second step, it chooses the optimal mix of spending across type $k$ and sourcing country $i$, taking as given optimal expenditure for each good type $k$ and hence public expenditure and optimal taxation. Separability implies that only this last step determines directly bilateral trade flows. Crucially, taxation does not affect bilateral trade flows under the "conditional general equilibrium" (Anderson and van Wincoop, 2004), as long as it does not come from border tariffs, which we assume throughout. While this limits the scope of the theory, it enables us to focus on trade costs. ${ }^{12}$

Under this structure, the CES demand function for intermediate goods is:

$$
X_{i j}^{k, s}=\left(\frac{p_{i}^{k, s} t_{i j}^{k, s}}{P_{j}^{k, s}}\right)^{1-\sigma^{k}} E_{j}^{k, s}
$$

Eaton-Kortum model), labour can freely move across sectors and hence across productions for governments and for other firms.

${ }^{10}$ Private firms provide the private good aggregate under perfect competition.

${ }^{11}$ Cobb-Douglas preferences across public and private good aggregates satisfy this condition (e.g., see Larch and Lechthaler (2013)).

${ }^{12}$ Changes in trade costs affect the optimal allocation of resources across sources of good $k$, without altering the overall expenditure (and hence income for the exporting countries) on good $k$. This result clearly hinges upon the type of analysis that we are after. In a full general equilibrium model, changes in the patterns of trade alter factory gate prices and hence income and expenditure. 
where $P_{j}^{k, s} \equiv\left[\sum_{i}\left(p_{i}^{k, s} t_{i j}^{k, s}\right)^{1-\sigma^{k}}\right]^{1-\sigma^{k}}$ is the market $s$ price index of good type $k$ - i.e. the unit cost that market $s$ faces to buy a bundle $k$ of intermediate input varieties. The term $\sigma_{k}>1$ is the elasticity of substitution between varieties of intermediate good class $k$ and is assumed to be equal across public and private market. Using market clearance on the supply side, $Y_{i}^{k, s}=\sum_{j}\left(p_{i}^{k, s} t_{i j}^{k, s} / P_{j}^{k, s}\right)^{1-\sigma^{k}} E_{j}^{k, s}$ to solve for the exogenous factory prices, we obtain the structural gravity model for each buyer $s \in\{p, r\}$ :

$$
\begin{aligned}
X_{i j}^{k, s} & =\frac{E_{j}^{k, s} Y_{i}^{k, s}}{Y^{k, s}}\left(\frac{t_{i j}^{k, s}}{P_{j}^{k, s} \Pi_{i}^{k, s}}\right)^{1-\sigma^{k}} \\
\left(P_{j}^{k, s}\right)^{1-\sigma^{k}} & =\sum_{i}\left(\frac{t_{i j}^{k, s}}{\Pi_{i}^{k, s}}\right)^{1-\sigma^{k}} \frac{Y_{i}^{k, s}}{Y^{k, s}} \\
\left(\Pi_{i}^{k, s}\right)^{1-\sigma^{k}} & =\sum_{j}\left(\frac{t_{i j}^{k, s}}{P_{j}^{k, s}}\right)^{1-\sigma^{k}} \frac{E_{j}^{k, s}}{Y^{k, s}}
\end{aligned}
$$

where $Y^{k, s} \equiv \sum_{i} Y_{i}^{k, s}$ denotes world income generated from supplies of good $k$ to buyer $s$. The $\Pi_{i}$ 's terms are referred to as "sellers' incidence" or "inward multilateral resistance", while the price indexes $P_{j}$ 's are suitably re-interpreted as "buyers' incidence" or "outward multilateral resistance" (Anderson and van Wincoop, 2003; Anderson and Yotov, 2010b). These terms summarize the average trade resistance between one country and the rest of the world. The system can be solved for the $P_{j}$ 's and $\Pi_{i}$ 's terms (up to a scalar) given data on income and expenditure and estimates of the trade cost vector $\left\{t_{i j}\right\} .{ }^{13}$

The structural gravity model can be used to derive a theoretically-consistent index of home bias, defined as the amount of predicted internal trade given trade costs relative to the same internal flow that would arise in a frictionless benchmark. In absence of trade barriers $\left(t_{i j}=1 \forall i, j\right)$, trade flows are proportional to income and expenditures shares: $X_{i, i}^{k, s}\left(t_{i j}=\right.$ 1) $=Y_{i}^{k, s} E_{i}^{k, s} / Y^{k, s}$. The "Constructed Home Bias" (CHB) index (Anderson and Yotov, 2010b)

\footnotetext{
${ }^{13}$ A gravity-type equation for bilateral cross-border procurement flows can be obtained also in the framework of Fronk (2014), where prices are determined in a first-price sealed-bid auction similar to McAfee and McMillan (1989). In his model, bilateral flows are still a function of importer-specific terms, exporter-specific terms, and bilateral factors, but the theoretical counterparts of some terms are different from those of eq (2) - e.g., the set of importer-specific terms include the expected (average) price of procurement contracts and a measure of competitiveness of the procurement market.
} 
is thus:

$$
C H B_{i}^{k, s} \equiv\left(\frac{t_{i i}^{k, s}}{\Pi_{i}^{k, s} P_{j}^{k, s}}\right)^{1-\sigma^{k}}
$$

This index summarizes how trade costs around the world inflates domestic shipments over international trade, holding aggregate sales and expenditure constant. It thus provide a specific measure of preference for local suppliers that can be computed for both the private and public market.

As Anderson and Yotov (2010b) argue, the CHB index is comparable across type of goods and services, countries and over time, does not depend on normalization nor on estimates of $\sigma^{k}$. Importantly, it can be estimated given the structure of the gravity equation. As such, the estimated index is meant to capture central tendency in the data and hence share the good empirical properties of the gravity equation. ${ }^{14}$ The CHB index is derived in eq (5) under a conditional general equilibrium analysis, which means that sales and expenditures (the $Y$ 's and the E's) do not change between the observed and the counterfactual (frictionless) scenario. ${ }^{15}$ As in Anderson and Yotov (2010b), this approach is consistent with a strict interpretation of $\mathrm{CHB}$ as a measure of the incidence of trade costs.

\section{Empirical specification and data}

Given data on the value of bilateral sectoral shipments $X_{i j}^{k, s}$ and proxies for the trade cost function $t_{i j}^{k, s}$, the parameters of the gravity equation in (2) can be consistently estimated. We follow common practice in the literature and use importer-year and exporter-year fixed effects in our panel regressions to control for the multilateral resistance and the sales and expenditure terms in eq (2). Adding a time subscript, the gravity model that we estimate is:

$$
X_{i j, t}^{k, s}=\exp \left(m_{j, t}^{k, s}+e_{i, t}^{k, s}+\alpha^{k, s} T_{i j, t}^{k, s}\right)+\varepsilon_{i j, t}^{k, s}
$$

\footnotetext{
${ }^{14}$ Another approach to measure trade cost is to solve the gravity equation in (2) for bilateral trade costs $t_{i j}$ 's (Novy, 2013). This measure however does not directly relate to the concept of home bias and, more importantly, is based on actual data. As we expect important measurement error to affect our data, we consider this approach in our application inferior to the CHB one.

${ }^{15}$ Holding taxation fixed, sales and expenditure would vary between the baseline, observed scenario and a counterfactual one because factory gate prices (and, in a supply-side model, factor prices) would change in response to changes in the levels of trade barriers.
} 
The term $T_{i j, t}^{k, s}$ is the matrix of possibly time-varying bilateral trade cost variables and $\alpha_{t}^{k, s}$ is the associated vector of coefficients: $\left(t_{i j, t}^{k s}\right)^{\phi^{k, s}\left(1-\sigma_{k}\right)} \equiv \exp \left(\alpha_{t}^{k, s} T_{i j, t}^{k, s}\right)$; where the empirical parameter $\phi^{k, s}$ measures the elasticity of 'true' trade costs with respect to the 'observed' ones, and is allowed to vary by type of good and buyer. The $m$ and $e$ terms denote importer-year and exporter-year fixed effects, each specific to a buyer and type of good. To avoid collinearity and consistently with the structural gravity model in eq (2) (see Anderson and Yotov, 2010b), we normalize $\exp \left(m_{U S A, t}^{k, s}\right)=1 \Rightarrow P_{U S A, t}^{k, s}=1$ in all our estimations. ${ }^{16}$

In specifying the trade cost function, we follow two approaches. First, we include time-invariant determinants of trade barriers that have been extensively used in the literature in addition to time-variant and policy-driven variables - including measures that capture changes in trade barriers specific to the public procurement market. In this case, the trade cost function is specified as follows:

$$
\begin{aligned}
\left(t_{i j, t}^{k s}\right)^{\phi^{k, s}\left(1-\sigma_{k}\right)} \equiv & \exp \left(\beta_{1}^{k, s} S M C T Y_{i j}+\beta_{2}^{k, s} D I S T_{i j}+\beta_{3}^{k, s} C O N T I G_{i j}+\beta_{4}^{k, s} C O L O N Y_{i j}\right) \\
& \exp \left(\beta_{5}^{k, s} L A N G_{i j}+\beta_{6}^{k, s} L E G A L_{i j}+\beta_{7}^{k, s} T A N O P R O C_{i j, t}+\beta_{8}^{k, s} T A P R O C_{i j, t}\right) \\
& \exp \left(\beta_{9}^{k, s} W T O G P A_{i j, t}+\beta_{10}^{k, s} E U_{i j, t}\right)
\end{aligned}
$$

where the $S M C T Y$ indicator equals one if $i=j$, i.e. if the the trade flow is internal. The coefficient $\beta_{1}$ thus identifies the (partial) border effect, i.e. how much trade within national borders is different from trade with other countries, controlling for other bilateral determinants of trade and for multilateral resistance terms. We control for a standard set of other time-invariant determinants of bilateral trade. The variable DIST is the the $\log$ of the population-weighted bilateral distance (Mayer and Zignago, 2011). CONTIG is a dummy equal to one if the two countries in the pair share a border, COLONY equals one if the two countries share colonial history, $L A N G$ equals one if the two countries share an official language, and $L E G A L$ is a dummy for common legal origin. These variables are sourced from CEPII (Mayer and Zignago, 2011).

The other determinants of trade costs are variables that measure participation in trade agreements, with a focus on trade policies related to government procurement. The TANOPROC indicator equals one if the two countries in the pair are part of a TA at time $t$

\footnotetext{
${ }^{16}$ Given our structural interpretation of the model, the normalization implies that $\left(P_{j, t}^{k, s}\right)^{1-\sigma_{k}}=$ $E_{j, t}^{k, s} / E_{U S A, t}^{k, s} \exp \left(m_{j, t}^{k, s}\right)$. It follows that $P_{U S A, t}=1$.
} 
without any provision on government procurement. The TAPROC dummy captures instead country pairs that are involved in TAs that explicitly include a chapter on government procurement. In extensions, we also estimate the impact of single provisions on government procurement as collected in the Deep Trade Agreements (DTA) database (Mattoo et al., 2020). The variable WTOGPA equals one for country pairs where both countries are members of the WTO GPA. ${ }^{17}$ Among the 62 countries of our sample, 28 are EU members at some point in time. We isolate the distinctive role of the EU by adding a dummy for EU membership. The TA variables are mutually exclusive - i.e., the TANOPROC and $T A P R O C$ dummies are turned to zero for EU countries when the $E U$ indicator is equal to one.

We first compare estimates of the trade cost function across public and private markets, for goods and services. We focus on the estimates of the coefficient on the SMCTY dummy as it captures the border effect and hence can used as a first indicator of bias towards local purchases. We then assess whether policy efforts to liberalize government procurement markets have increased cross-border flows. Specifically, we test if the coefficients on the TA and GPA dummies are positive and significant and if they are higher for government than for private flows. The estimated coefficients on these trade policy variables in eq (7) are likely to be biased because the specification does not fully control for unobserved time-invariant heterogeneity that can drive both the propensity to increase cooperation through various agreements and trade flows (Baier and Bergstrand, 2007). To control for this unobserved heterogeneity, we estimate the following specification:

$\left(t_{i j, t}^{k s, F E}\right)^{\phi^{k, s}\left(1-\sigma^{k}\right)} \equiv \exp \left(\beta_{1}^{k, s} T A N O P R O C_{i j, t}+\beta_{2}^{k, s} T A P R O C_{i j, t}+\beta_{3}^{k, s} W T O G P A_{i j, t}+\beta_{4}^{k, s} E U_{i j, t}+\gamma_{i j}^{k, s}\right)$

where the $\gamma$ 's terms are bilateral fixed effects that capture unobserved and time-invariant determinants of trade costs. ${ }^{18}$

Our interest is in the (partial) effect of trade agreements. ${ }^{19}$ We isolate the effect of

\footnotetext{
${ }^{17}$ While the agreement entered officially into force in 1996, it was firstly singed in 1994 . We thus assume that the countries that entered the agreement in 1996 were already de facto members in 1995, the first year of our panel.

${ }^{18}$ Collinearity requires further restrictions on the set of bilateral fixed effects. As in Agnosteva et al. (2019), we suppress the time-invariant internal trade cost dummies so that the estimates of international time-invariant trade costs are relative to a geometric mean of the two countries' internal trade cost: $\exp \left(\gamma_{i j}^{k, s}\right)=\left[t_{i j}^{s, k} /\left(t_{i i}^{s, k} t_{i j}^{s, k}\right)^{1 / 2}\right]$.

${ }^{19}$ The effect of trade agreements directly implied by the estimated coefficients in eq (10) is 'partial' in
} 
EU membership as almost half of the countries in our sample are members of the EU and the agreement is arguably the deepest form of economic integration among states, including specific directives on government procurement. Two policy variables should account for trade liberalization specific to government procurement. One is an indicator for the presence of provisions on government procurement in TAs. We draw from the Deep Trade Agreements database (Mattoo et al., 2020), which includes a section on the presence of around 100 provisions specific to government procurement in each TA. In our baseline specifications, we use a simple dummy, TAPROC for the presence of provisions on government procurement in an agreement. The other variable is a dummy for membership in the WTO GPA. Started in 1996 and revised in 2014, the agreement aims to ensure national treatment to foreign firms in government procurement markets, although each member defines the areas of commitments (e.g. different public entities, goods vs. service) that can thus vary substantially across countries. Importantly and unlike most of the WTO agreement, the GPA is "plurilateral", meaning that it binds only its signatories having de facto the same structure of a preferential TA.

To take into account how trade barriers around the world create a preference for local purchases, we next estimate an index of home bias, the CHB. Differently from the border effect, the CHB measures how trade frictions shift up the observed internal trade relative to a frictionless benchmark, where international transactions are thus predicted to be much greater. To estimate the index, we manipulate the gravity equation in eq (2) as follows (see Anderson and Yotov, 2010b):

$$
\widehat{C H B}_{i, t}^{k, s}=\frac{Y_{t}^{k, s} \widehat{X}_{i j, t}^{k, s}}{E_{j, t}^{k, s} Y_{i, t}^{k, s}}=\frac{\left(\hat{t}_{i i, t}^{k, s}\right)^{\widehat{\phi}^{k, s}\left(1-\sigma^{k}\right)}}{\left(\widehat{P}_{j, t}^{k, s} \widehat{\Pi}_{i, t}^{k, s}\right)^{1-\sigma^{k}}}
$$

where the $\widehat{\phi}$ term reflects the fact that we observe only an empirical estimates of trade costs (instead of the true ones). The estimated CHB is thus given by the predicted values of the gravity model rescaled by sectoral expenditures and incomes. The predictions are from the gravity specification in eq (10). We first obtain CHB for goods and services separately (and for each market $s$ ) and then aggregate those to the country level using the product of sales and expenditure shares as weights, similar to Anderson et al. (2014).

contrast to the 'full' general-equilibrium effect that takes into account the influence on trade flows through multilateral resistance terms, sales and expenditure. 
This approach gives consistent estimates of the CHB index if the gravity equation is correctly specified, i.e. if the country-specific fixed effects are consistent estimates of their theoretical counterparts. Fally (2015) shows that this automatically holds true when the Poisson pseudo-maximum-likelihood (PPML) estimator proposed by Silva and Tenreyro (2006) is employed and income and expenditure are consistent with bilateral trade flows (i.e., $Y_{i, t}^{k, s}=\sum_{j} X_{i j, t}^{k, s} ; E_{j, t}^{k, s}=\sum_{i} X_{i j, t}^{k, s}$ ). The peculiar properties of the estimator implies that the actual income and expenditure values equal the predicted ones, which should normally be used as both are endogenous in the general equilibrium gravity model. We thus employ the PPML estimator, which has the added advantages of controlling for heteroskedasticity in the data and statistically dealing with zero trade flows. The gravity equation in eq (6) is estimated separately for each market $s$ and sector $k$, although covariances of the estimated coefficients are taken into account when testing significance of the difference in across public and private gravity.

To bring this empirical artillery to the data, we need information on bilateral trade that involves the public sector as a buyer, on a large enough sample of countries. Other studies that investigate trade barriers in government procurement employ data from inter-country input-output tables (Riker, 2013; Messerlin and Mirodout, 2012) as these can split public expenditures from national accounts across type of goods and services purchased and country of origin. We thus follow this route and employ data from the TiVA initiative of the OECD. Similarly to other ICIO database (e.g., Timmer, 2012), the TiVA database harmonizes national IO tables and combines them with information from national accounts and bilateral trade statistics in goods and services to obtain an international input-output table (see OECD, 2013b for details). The estimation procedure allocates output from each country and sector to intermediate usage (by all sectors) or final demand across countries. While far from perfect and inevitably rife with measurement errors (especially compared with official trade statistics), this type of data is the only one that enables international comparison of public expenditures across countries and sectors. ${ }^{20}$ Data on procurement contracts that has been used in related work (Herz and Varela-Irimia (2020); Fronk (2014); see also footonote 5) are limited to one or to a group of countries (U.S. or the EU) and

\footnotetext{
${ }^{20}$ An alternative approach that relies only on official trade statistics is used by Rickard and Kono (2014) (and adopted also by Gourdon and Messent (2019)). It indirectly identifies the effect of trade barriers on cross-border government procurement by allowing the effect of bilateral factors on trade as recorded by official statistics to vary with the size of the government procurement sector by country. An important limitation of this approach in our setting is that it departs from a structural gravity model: total government purchases, that enter overall expenditure in the gravity equation, are allowed to influence the direct effect of trade costs.
} 
hence would make identification of the effect of different TAs problematic.

We combine the 2018 and 2016 editions of the TiVA database to obtain data on 62 countries, for goods and services, between 1995 and 2015. The 2016 edition covers the 1995-2011 period, while the 2018 edition covers the 2005-2015 period. We employ data from the 2016 edition from 1995 to 2004, and data until 2015 from the latest edition. The sector classifications in the two editions are not fully compatible. The 2018 edition uses the ISIC Rev. 4 classification, whereas the 2016 edition is based on the ISIC Rev. 3 one. While harmonization of the two classifications at the sector-level can be problematic ${ }^{21}$, the definitions of the goods and services aggregate sectors, and of the 'buying' sectors composing government entities did not change. We therefore conduct our analysis with the aggregates of goods and services. Table A1 in the Appendix lists the goods and services sectors that are included in the data. As for the country composition, Kazakhstan is included in the 2018 edition only, whereas Thailand never reports imports in public procurement (no imports are reported also in the Government Expenditures column). Therefore, we exclude both countries from the analysis. For simplicity, we also exclude the Rest-of-the-World aggregate that is part of the dataset.

To measure government procurement flows, we have to define the perimeter of the public sector. The OECD defines public procurement as "intermediate consumption (goods and services purchased by governments for their own use, such as accounting or IT services), gross fixed capital formation (acquisition of capital excluding sales of fixed assets, such as building new roads) and social transfers in kind via market producers (goods and services produced by market producers, purchased by government and supplied to households)" (OECD, 2013a, p.130). We cannot measure gross fixed capital formation by the public sector because the TiVA database, like other ICIO data, does not provide a split between public and private gross fixed capital formation. We measure social transfers in kind with the entries under the "General Government Expenditure" component of final demand. To measure intermediate consumption, we take the column vectors from the input-output matrix that correspond to government entities. The European Commission (2017) proposes three ways to define these entities in an input-output matrix: (i) a "narrow" classification that includes only the "Public Administration" column; (ii) a "typical" definition that adds the "Health" and "Education" columns to the "Public Administration" one; and (iii) a

\footnotetext{
${ }^{21}$ See this note: http://www.oecd.org/industry/ind/tiva-2018-differences-tiva-2016.pdf from the OECD on the subject.
} 
"broad" classification that adds to the "typical" one the columns that pertain to utilities, half of the columns with postal and telecommunication services, and one third of the land transport column. The empirical evidence that we present in this and in the next sections relies on the "typical" definition, and we check the robustness of our main results to the use of the "narrow" definition (the results are shown in the Appendix). Because the TiVA data are not detailed enough (i.e., land transportation is included in a broader "transport and storage" sector), we cannot appropriately implement the "broad" definition.

Once public procurement is defined, we identify a private market that is suitable for comparisons. The sum of the other columns in the ICIO table and the "Household expenditure" column in the final demand section is the most immediate and comparable definition of 'private procurement'. This choice can nevertheless lead to an overlapping with government procurement to the extent to which public authorities operate outside the "typical" definition of government (i.e., outside the Public Administration, Health, and Education columns). Such an overlap between the public and private markets should work against finding significant differences in trade barriers between the two.

\section{Descriptive trends}

Before turning to the empirical estimates of the gravity models, we investigate descriptive trends in the data. The objective here is twofold: (i) to identify patterns of expenditures across goods and services in public and private markets as these affect estimated home bias at the country-level; and (ii) to have a first look at trade barriers by looking at import penetration ratios. First, we compute the service expenditure share for each country in the 'typical' public and private markets as defined above. Figure 2 reports this share for 1995 and 2015, the first and the last years of our sample. One pattern stands out: government procurement is vastly about services. The average government in our sample devotes to services around 90 percent of total procurement purchases in 1995 and 2015. Importantly, the share of pubic purchases on various services is higher than the same share for the private market. $^{22}$

\footnotetext{
${ }^{22}$ This pattern is confirmed when we adopt the "narrow" definition of government procurement, as shown in Figure A1 in the Appendix.
} 
Figure 2: Services share of purchases in public and private markets
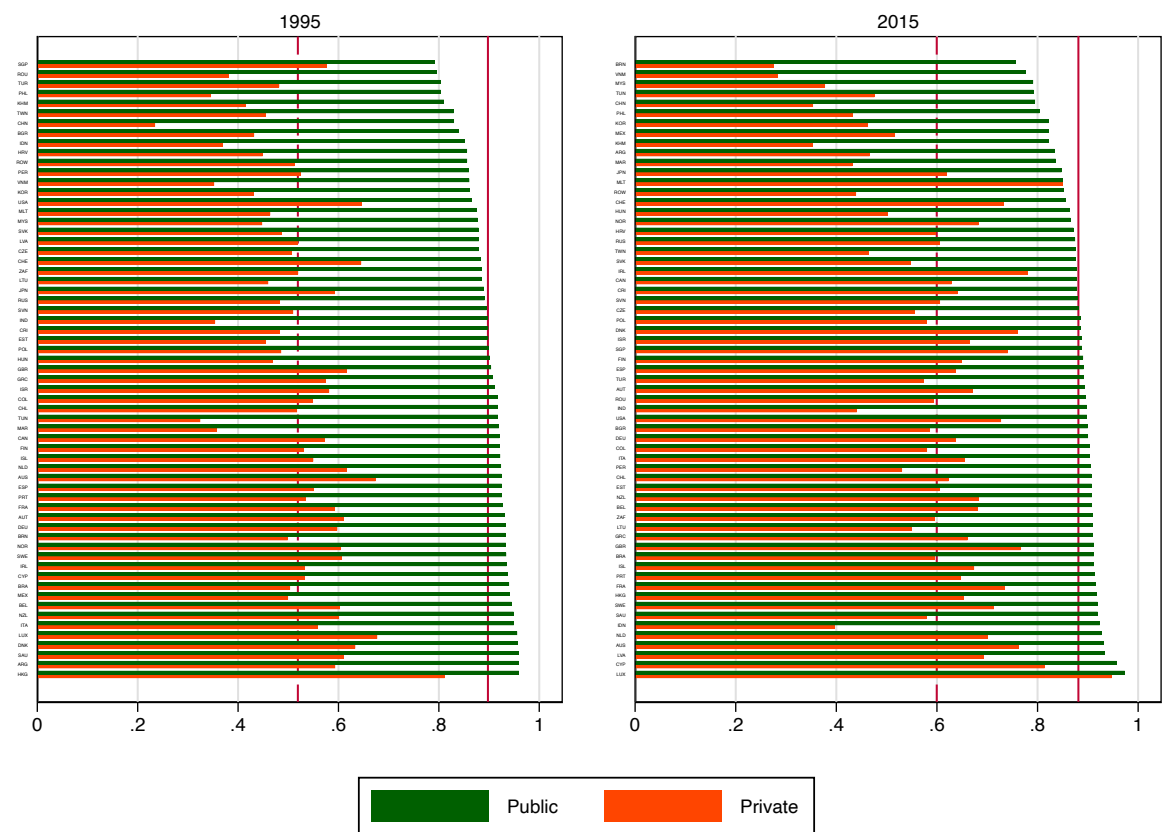

Note: Raw data are sourced from the TiVA database. Public procurement flows are computed using the "typical" definition (see the main text for details). The vertical solid line indicates the average service share in public procurement across countries. The dashed line reports the same average for private markets.

We then turn to import penetration ratios defined as the value of imports divided by total expenditures. While purely descriptive, the measure has been used extensively to assess openness to trade, including in government procurement markets (Messerlin and Mirodout, 2012). We compute the import penetration ratios by country and type of purchasing entities (public or private). Figure 3 reports the ratio of public to private import penetration ratios for goods and services. A value greater than one suggests that public markets are more open than private ones. Public markets are less open than private ones in services for all countries, while for goods the picture is more nuanced. Between 1995 and 2015, relative openness of government procurement in services increases, whereas it slightly decreases on average for goods. ${ }^{23}$

\footnotetext{
${ }^{23}$ When using the "narrow" definition of government procurement in Figure 2 in the Appendix, we find similar results: if anything, the relative government import penetration is lower especially in services.
} 
Figure 3: Government import penetration/ Private import ratio by country
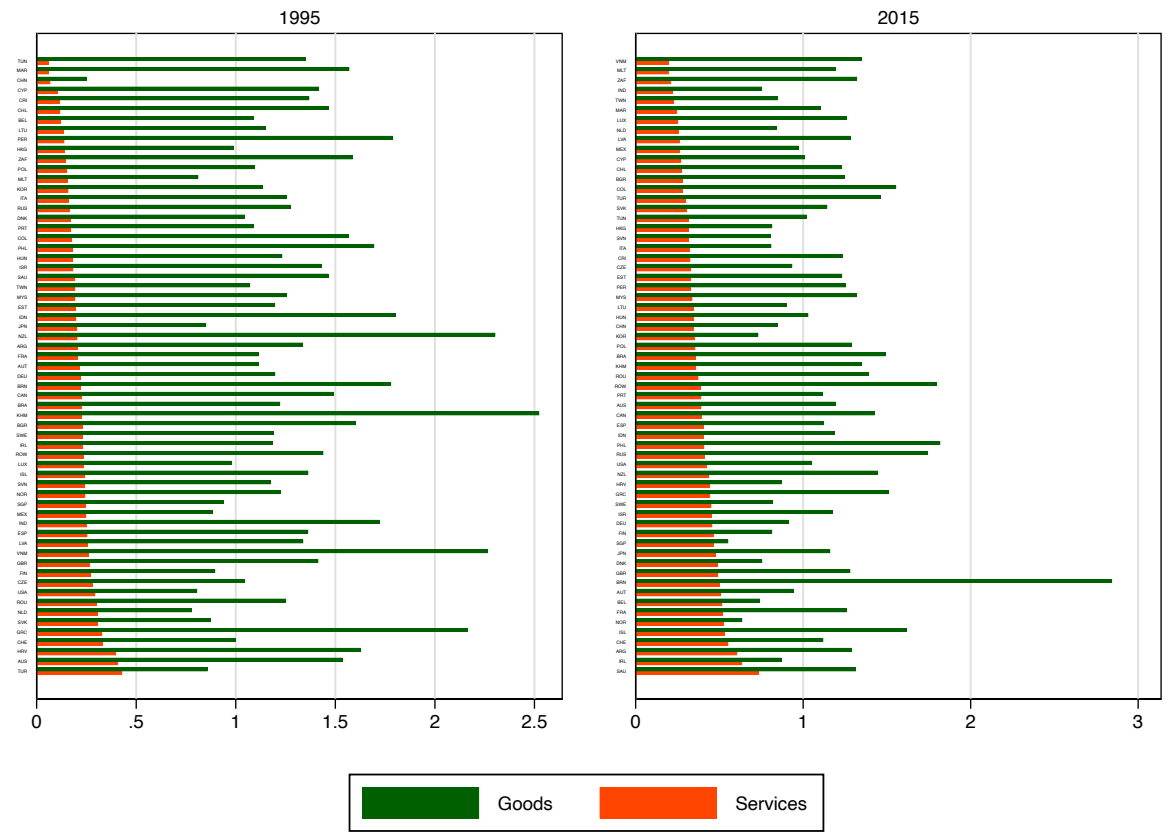

Note: Raw data are sourced from the TiVA database. Public procurement flows are computed using the "typical" definition (see the main text for details).

While purely illustrative, this descriptive analysis delivers some messages that are relevant to the subsequent econometric analysis. Government procurement is mainly about services, which are generally less traded than goods. These two observations alone mechanically increase home bias in the public sector at the country level as services are weighted more in the public expenditure basket than in the private one. The sector-specific gravity model in eq (6) controls for this influence as it allows comparisons of estimates across public and private markets within the goods or services aggregate. The analysis of import penetration ratios indeed suggests that already within services, public markets are less open than private ones, with important heterogeneity across countries and over time. The ensuing empirical analysis aims to investigate this variation further.

\section{$5 \quad$ Empirical results}

In this section, we discuss the estimates from the gravity equation (6) and the estimated CHB. The objective is to estimate the border effect in government procurement and the effect of TAs (relative to private markets) by applying the empirical framework described in section 3 . 
To make the analysis clearer and in line with the descriptive evidence, we sum up bilateral trade values over supplying sectors in a goods (including also primary sectors) and a services aggregates. To allow for adjustments over time in trade flows (Piermartini and Yotov, 2016), we use data from six years in four-year intervals $(1995,1999,2003,2007,2011,2015)$. We report robustness checks by (i) leaving the dependent variable at the sector level (see Table A1 in the Appendix) and allowing for sector-specific multilateral resistances; and (ii) using the full 1995-2015 yearly panel of country pairs. For each specification and supplying sector, we report the estimates for the private market next to the ones for the government one to ease comparison. Coefficients in bold are significantly different (at the 10\% level) across the two markets.

\subsection{Gravity results}

Tables 1 and 2 report the PPML gravity estimates for goods and services, respectively. In columns (1) and (2), we use the 'pooled' specification - controlling for exporter-year and importer-year fixed effects (see eq (7)). The large and significant coefficient on the 'same country' dummy ( $S M C T Y$ variable) gives a strong indication of home bias, especially in government procurement. All other trade cost variables (except for distance) are switched off for same-country pairs, so that the omitted category for the 'same country' variable includes country-pairs that have, for instance, no contiguous border, a different official language and are no EU members. For trade in goods (Table 1), the estimates in column (1) imply that, relative to the omitted category, government procurement from local suppliers is around 30 times higher. In private markets, local sales are 23 times higher than international sales. As expected, the border effect is much larger in services, and significantly higher in government procurement than in private markets (Table 2). The estimates in column (1) suggest that government purchases of local services are almost a thousand times the purchases of services from abroad. The disproportionately large border effect in government procurement is only an indication of protectionist trade policies (e.g., 'buy-national' policies). Other characteristics that are specific to government contracts and that are not protectionist might still end up favouring local over foreign firms. In the U.S. for instance, set-aside policies that provide preferences for certain categories of firms (e.g., small and medium sized firms, veteran- or Native-owned firms) can indirectly exclude foreign bidders from competition. 
The common language and legal origin dummy variables in the gravity equation can control, at least partially, for a local bias in government procurement due to cross-country differences in the legal language and procedure. The estimates indeed suggest that speaking the same official language increases significantly cross-border procurement, but the effect is not significantly different than the one on trade in private markets. Sharing the same type of legal system does not seem to affect trade flows. Coefficients on the other time-invariant determinants of trade costs have the expected sign and most of them are statistically significant. Distance has the usual depressing role on bilateral trade, regardless of whether the purchaser is a private or public entity. The negative effect is rather on the lower end of the range of distance effects found in the literature (Disdier and Head, 2008) and, interestingly, it is significantly lower (in absolute terms) in goods and stronger in services for public compared to private purchases. Time-varying and policy-driven determinants of trade are included in columns (1) and (2) of Tables 1 and 2 merely as controls. Omitted variable bias is likely to plague their partial effects on trade.

Columns (3) to (10) report the estimates of gravity models with country-pair fixed effects, which absorb the influence of all time-invariant determinants of trade flows (e.g., see the specification in eq (10)). As Baier and Bergstrand (2007) argue, this specification attenuates the endogeneity concerns related to the coefficients on time-varying variables measuring changes in trade policy. The implied effects of trade agreements are 'partial' as the multilateral resistance terms, sales, and expenditure are taken as given.

Since many countries are part of multiple types of agreements relevant to government procurement (e.g., countries sign deep TAs with procurement provisions, while being part of the WTO GPA and - relevant to our sample of countries - of the EU), we assess the contribution of each type of agreement by adding them progressively to our specification. The PPML estimates in Table 1 point to weak effects of initiatives specific to government procurement (i.e., TAs with provisions on government procurement and WTO GPA) on trade in goods. The estimates in column (5) suggest that cross-border government procurement in goods goes up by 20 percent when two countries join an TA with procurement provisions, but the effect is actually lower than that of joining an TA without those provisions. The effect of the WTO GPA is instead null. Furthermore, we find that the effect of these policies that are meant to liberalize government procurement is even slightly lower than in private markets. These findings suggest that TAs have not been particularly instrumental in boosting cross-border procurement of goods. When it 
comes to goods trade, policies specific to procurement markets included in TAs might partly be proxying for the effect of provisions in other areas (e.g., non-tariff measures, investments).

Trade agreements have instead significant and important effects on cross-border government procurement in services. As Table 2 shows, most of the average trade effect of TAs is driven by those that have specific provisions on government procurement. The estimates in column (5) imply that entering an TAs with provisions on government procurement boosts trade in public markets by 77 percent - the relative effect on private markets being only a 15 percent increase - compared to the 37 percent increase brought about by TAs without procurement provisions. Columns (7) and (9) show that part of this distinctive effect of procurement provisions is driven by other policy initiatives: WTO GPA and the EU. In particular, membership to the WTO GPA increases significantly cross-border public procurement of services - an effect that is even larger than that of TAs with procurement provisions. Entering the EU single market has promoted the most cross-border purchases of services by public authorities, as shown in column (9). Looking at the estimates for private markets, the positive effects of TAs with procurement provisions and of the WTO GPA disappear when we control for the EU dummy (column (10)): as expected, it is EU membership that boosts trade in services between firms, and not trade policies specific to government procurement.

Going from column (3) to column (9), the effect of deep TAs with procurement provisions is almost halved, suggesting that the trade creating effects of these TAs partly overlap with those of the WTO GPA and of the EU single market. The confounding effects of deep TAs and the WTO GPA is not surprising. Anderson et al. (2017) find that the legal text of chapters on government procurement in preferential trade agreements is often similar to the one of the WTO GPA (especially of the revised GPA that entered into force in 2014). In our sample of 62 countries, the likelihood that a country is part of a preferential trade agreement with provisions on government procurement with at least another country in a given year equals 95 percent for GPA members, and only 34 percent for non-GPA members. In other words, almost all GPA signatories participate also in a TA with procurement provisions in our sample. The disproportionate presence of EU countries in our sample and the depth of trade agreements signed by the EU with other countries makes identification of separate effects of EU and TA memberships also problematic. Our gravity estimates for services thus indicate that each of these trade policies (preferential trade agreements, WTO GPA, and the EU) have a distinctive trade-creating effect when it comes to government 
procurement.

The evidence on the border effect and on the trade effects of TAs and their provisions is confirmed in three sets of robustness checks, whose results are reported in the Appendix. Tables A2 and A3 show that the estimates of the gravity models are similar when we use an alternative "narrow" definition of government procurement, which excludes purchases recorded in the "Health" and "Education" columns in the TiVA input-output tables. Results are confirmed also if we estimate the gravity models using the full yearly panel (Tables A4 and A5). ${ }^{24}$ Finally, we confirm our baseline findings when the dependent variable is further disaggregated by the components of the goods and services sectors listed in Table A1. In Tables A6 and A7, the regressions control for country-industry-year fixed effects, consistent with an industry-level gravity model, while we maintain country-pair fixed effects, which reflect the assumption that trade costs vary across services and goods but not within each of the two aggregates. The estimates are close to the baseline ones in Tables 1 and 2. One difference is that the results for goods are even weaker than in the baseline - e.g., WTO GPA membership is now negatively associated with cross-border procurement.

\footnotetext{
${ }^{24}$ Egger et al. (2020) argue for the use of annual data for the estimation of the dynamic trade effects of TAs. Their results nonetheless confirm that using annual or time-interval data does not affect substantially the contemporaneous effects, which are the focus of our paper. Future work might investigate the anticipated and lagged effects of trade agreements on cross-border government procurement.
} 
Table 1: PPML Gravity estimates, Goods

\begin{tabular}{|c|c|c|c|c|c|c|c|c|c|c|}
\hline & $\begin{array}{l}(1) \\
\text { Gov. }\end{array}$ & $\begin{array}{c}(2) \\
\text { Priv. }\end{array}$ & $\begin{array}{l}(3) \\
\text { Gov. }\end{array}$ & $\begin{array}{c}(4) \\
\text { Priv. }\end{array}$ & $\begin{array}{l}(5) \\
\text { Gov. }\end{array}$ & $\begin{array}{c}(6) \\
\text { Priv. }\end{array}$ & $\begin{array}{l}(7) \\
\text { Gov. }\end{array}$ & $\begin{array}{c}(8) \\
\text { Priv. }\end{array}$ & $\begin{array}{l}(9) \\
\text { Gov. }\end{array}$ & $\begin{array}{l}(10) \\
\text { Priv. }\end{array}$ \\
\hline Same country & $\begin{array}{c}3.439 * * * \\
(0.176)\end{array}$ & $\begin{array}{c}3.147^{* * *} \\
(0.187)\end{array}$ & & & & & & & & \\
\hline Contiguity & $\begin{array}{c}0.239^{* *} \\
(0.121)\end{array}$ & $\begin{array}{c}0.280^{* *} \\
(0.126)\end{array}$ & & & & & & & & \\
\hline Common language & $\begin{array}{c}0.352^{* * *} \\
(0.108)\end{array}$ & $\begin{array}{c}0.277^{* * *} \\
(0.101)\end{array}$ & & & & & & & & \\
\hline Colony & $\begin{array}{c}0.290^{*} \\
(0.159)\end{array}$ & $\begin{array}{c}0.385 \\
(0.240)\end{array}$ & & & & & & & & \\
\hline Ln Distance & $\begin{array}{c}-\mathbf{0 . 6 5 1} \text { **** } \\
(0.049)\end{array}$ & $\begin{array}{c}-\mathbf{0 . 8 1 2} * * * \\
(0.051)\end{array}$ & & & & & & & & \\
\hline Common legal origin & $\begin{array}{c}-0.002 \\
(0.083)\end{array}$ & $\begin{array}{c}0.041 \\
(0.082)\end{array}$ & & & & & & & & \\
\hline $\mathrm{TA}$ & $\begin{array}{l}-0.086 \\
(0.120)\end{array}$ & $\begin{array}{c}0.038 \\
(0.135)\end{array}$ & $\begin{array}{c}0.214^{* * *} \\
(0.042)\end{array}$ & $\begin{array}{c}0.294^{* * *} \\
(0.037)\end{array}$ & $\begin{array}{c}0.384^{* *} \\
(0.152)\end{array}$ & $\begin{array}{c}0.318^{* * * *} \\
(0.098)\end{array}$ & $\begin{array}{c}0.385^{* *} \\
(0.152)\end{array}$ & $\begin{array}{c}0.318^{* * *} \\
(0.098)\end{array}$ & $\begin{array}{c}0.381^{* *} \\
(0.152)\end{array}$ & $\begin{array}{c}0.314^{* * * *} \\
(0.098)\end{array}$ \\
\hline $\mathrm{TA} \mathrm{w} /$ procurement & $\begin{array}{c}0.168 \\
(0.106)\end{array}$ & $\begin{array}{c}0.269^{* *} \\
(0.121)\end{array}$ & & & $\begin{array}{c}0.191^{* * *} \\
(0.043)\end{array}$ & $\begin{array}{c}0.288^{* * *} \\
(0.038)\end{array}$ & $\begin{array}{c}0.212^{* * *} \\
(0.045)\end{array}$ & $\begin{array}{c}0.274^{* * *} \\
(0.041)\end{array}$ & $\begin{array}{c}0.163^{* * *} \\
(0.048)\end{array}$ & $\begin{array}{c}0.218^{* * * *} \\
(0.039)\end{array}$ \\
\hline WTO GPA & $\begin{array}{c}0.596^{* * *} \\
(0.119)\end{array}$ & $\begin{array}{c}0.362^{* * *} \\
(0.124)\end{array}$ & & & & & $\begin{array}{l}-0.071 \\
(0.055)\end{array}$ & $\begin{array}{c}0.044 \\
(0.054)\end{array}$ & $\begin{array}{c}-0.171^{* * *} \\
(0.052)\end{array}$ & $\begin{array}{l}-0.088 \\
(0.063)\end{array}$ \\
\hline $\mathrm{EU}$ & $\begin{array}{c}0.064 \\
(0.118)\end{array}$ & $\begin{array}{c}0.126 \\
(0.105)\end{array}$ & & & & & & & $\begin{array}{c}0.499^{* * *} \\
(0.090)\end{array}$ & $\begin{array}{c}0.575 * * * \\
(0.069)\end{array}$ \\
\hline Obs & 20,886 & 20,886 & 20,886 & 20,886 & 20,886 & 20,886 & 20,886 & 20,886 & 20,886 & 20,886 \\
\hline
\end{tabular}

Note: All regressions include importer-year and exporter-year fixed effects. Columns (3) to (10) include also country-pair fixed effects. In columns (3) and (4), the TA dummy equals one if the two countries in the pair belong to the same TA (with or without provisions on government procurement). Data are for the years 1995, 1999, 2003, 2007, 2011 and 2015. Coefficients in bold are statistically different between the 'Gov.' and 'Priv.' regressions. Robust standard errors clustered at the country-pair level are in parentheses. Significant at: ${ }^{*} 10 \%,{ }^{*} * 5 \%, * * * 1 \%$ level.

Table 2: PPML Gravity estimates, Services

\begin{tabular}{|c|c|c|c|c|c|c|c|c|c|c|}
\hline & $\begin{array}{l}(1) \\
\text { Gov. }\end{array}$ & $\begin{array}{l}(2) \\
\text { Priv. }\end{array}$ & $\begin{array}{l}(3) \\
\text { Gov. }\end{array}$ & $\begin{array}{l}(4) \\
\text { Priv. }\end{array}$ & $\begin{array}{l}(5) \\
\text { Gov. }\end{array}$ & $\begin{array}{l}(6) \\
\text { Priv. }\end{array}$ & $\begin{array}{l}(7) \\
\text { Gov. }\end{array}$ & $\begin{array}{l}\text { (8) } \\
\text { Priv. }\end{array}$ & $\begin{array}{l}(9) \\
\text { Gov. }\end{array}$ & $\begin{array}{l}(10) \\
\text { Priv. }\end{array}$ \\
\hline Same country & $\begin{array}{c}6.992 * * * \\
(0.183)\end{array}$ & $\begin{array}{c}\mathbf{5 . 8 0 2} * * * \\
(0.196)\end{array}$ & & & & & & & & \\
\hline Contiguity & $\begin{array}{c}0.186 \\
(0.114)\end{array}$ & $\begin{array}{c}0.394^{* * *} \\
(0.128)\end{array}$ & & & & & & & & \\
\hline Common language & $\begin{array}{c}0.647^{* * *} \\
(0.106)\end{array}$ & $\begin{array}{c}0.608^{* * *} \\
(0.102)\end{array}$ & & & & & & & & \\
\hline Colony & $\begin{array}{c}0.674^{* * *} \\
(0.184)\end{array}$ & $\begin{array}{c}0.890^{* * * *} \\
(0.180)\end{array}$ & & & & & & & & \\
\hline Ln Distance & $\begin{array}{c}-0.446^{\text {*** }} \\
(0.053)\end{array}$ & $\begin{array}{c}-0.380^{* * *} \\
(0.057)\end{array}$ & & & & & & & & \\
\hline Common legal origin & $\begin{array}{c}0.075 \\
(0.071)\end{array}$ & $\begin{array}{c}0.067 \\
(0.081)\end{array}$ & & & & & & & & \\
\hline $\mathrm{TA}$ & $\begin{array}{c}0.353^{* *} \\
(0.158)\end{array}$ & $\begin{array}{c}0.401^{* * *} \\
(0.144)\end{array}$ & $\begin{array}{c}\mathbf{0 . 5 4 3} * * * \\
(0.057)\end{array}$ & $\begin{array}{c}\mathbf{0 . 0 8 7 ^ { * * }} \\
(0.041)\end{array}$ & $\begin{array}{c}\mathbf{0 . 3 1 8 ^ { * * * }} \\
(0.086)\end{array}$ & $\begin{array}{c}-0.207^{* *} \\
(0.100)\end{array}$ & $\begin{array}{c}\mathbf{0 . 3 1 7 * * *} \\
(0.085)\end{array}$ & $\begin{array}{c}-\mathbf{0 . 2 0 6} * * \\
(0.099)\end{array}$ & $\begin{array}{c}\mathbf{0 . 3 1 4 ^ { * * * }} \\
(0.085)\end{array}$ & $\begin{array}{c}-\mathbf{0 . 2 0 8 * *} \\
(0.099)\end{array}$ \\
\hline $\mathrm{TA} \mathrm{w} /$ procurement & $\begin{array}{l}-0.104 \\
(0.118)\end{array}$ & $\begin{array}{c}-0.071 \\
(0.121)\end{array}$ & & & $\begin{array}{c}\mathbf{0 . 5 7 2} \mathbf{2}^{* * *} \\
(0.064)\end{array}$ & $\begin{array}{c}\mathbf{0 . 1 4 8} * * * \\
(0.041)\end{array}$ & $\begin{array}{c}\mathbf{0 . 3 9 0 * * *} \\
(0.056)\end{array}$ & $\begin{array}{c}\mathbf{0 . 0 9 4}^{* *} \\
(0.043)\end{array}$ & $\begin{array}{c}\mathbf{0 . 3 2 6}^{* * * *} \\
(0.056)\end{array}$ & $\begin{array}{c}\mathbf{0 . 0 3 4} \\
(0.044)\end{array}$ \\
\hline WTO GPA & $\begin{array}{c}\mathbf{1 . 0 0 1 * * *} \\
(0.113)\end{array}$ & $\begin{array}{c}\mathbf{0 . 7 3 6} * * * \\
(0.105)\end{array}$ & & & & & $\begin{array}{c}\mathbf{0 . 4 2 7} * * * \\
(0.058)\end{array}$ & $\begin{array}{c}\mathbf{0 . 1 3 2}^{* * *} \\
(0.049)\end{array}$ & $\begin{array}{c}\mathbf{0 . 3 0 2}^{* * * *} \\
(0.055)\end{array}$ & $\begin{array}{c}\mathbf{0 . 0 4 1} \\
(0.052)\end{array}$ \\
\hline EU & $\begin{array}{c}0.032 \\
(0.128)\end{array}$ & $\begin{array}{c}0.110 \\
(0.116)\end{array}$ & & & & & & & $\begin{array}{c}\mathbf{0 . 6 6 9} \\
(0.08 * *\end{array}$ & $\begin{array}{c}\mathbf{0 . 3 3 7} \text { *** } \\
(0.065)\end{array}$ \\
\hline Obs & 20,886 & 20,886 & 20,886 & 20,886 & 20,886 & 20,886 & 20,886 & 20,886 & 20,886 & 20,886 \\
\hline
\end{tabular}

Note: All regressions include importer-year and exporter-year fixed effects. Columns (3) to (10) include also country-pair fixed effects. In columns (3) and (4), the TA dummy equals one if the two countries in the pair belong to the same TA (with or without provisions on government procurement). Data are for the years 1995, 1999, 2003, 2007, 2011 and 2015. Coefficients in bold are statistically different between the 'Gov.' and 'Priv.' regressions. Robust standard errors clustered at the country-pair level are in parentheses. Significant at: ${ }^{*} 10 \%,{ }^{*} 5 \%$, ${ }^{* * *} 1 \%$ level. 
The baseline results rely on the use of dummy variables to identify the presence of provisions on government procurement in TAs. The DTA database of Mattoo et al. (2020) however provides also detailed information on the inclusion of specific provisions in each TA. We thus exploit this information to gain a better understanding of the type of measures that can drive the average trade effect of covering government procurement in a TA. The database includes one hundred questions about the treatment of government procurement in the legal text of TAs. We consider the 'horizontal' depth of the government procurement chapters (if any) and exclude information about the treatment of certain provisions that are difficult to classify as moves towards opening up the market. ${ }^{25}$ After this cleaning of the data, we end up with 39 distinct provisions on government procurement.

We perform two distinct exercises to assess the role of different types of provisions. First, we rely on the gravity model with bilateral fixed effects (see columns (3) to (10) in Tables 1 and 2) to assess the trade effect of each provision on trade flows. Specifically, we run separate regressions of bilateral flows on an indicator variable for the presence of a provision, controlling for TAs with other government provisions, TAs without government procurement, WTO GPA and EU membership (the effect of the single provision is thus relative to a country pair that is not part of a TA at a given time). The results of this exercise are purely suggestive of the effect of each provision, because in reality many provisions come in clusters - this would create collinearity between the provision dummy and the dummy for the presence of other provisions on government procurement. In general, the presence of one provision can simply proxy for a broader liberalizing stance in government procurement (as captured by the general dummy variable used in the baseline results).

With this caveat in mind, we plot in figure A3 of the Appendix the statistically significant estimated coefficients when we consider government procurement in goods. The provision with the largest trade-creating effect concerns the disclosure of statistics and quantitative information of the country's procurement market. Provisions about the possibility to further expand coverage in the future ("Expansion coverage" and "Reduction discrimination") are among the most effective ones. Other provisions that should potentially be more relevant (e.g., whether the provisions in the procurement chapter are enforceable,

\footnotetext{
${ }^{25}$ We drop questions that measure 'vertical' depth - i.e., those about the content of phasing in provisions for developing countries, that compare the content of the provision with the corresponding article of the (revised) WTO GPA, and combine some questions that are mutually exclusive (e.g., whether the chapter covers only goods or goods and services).
} 
or whether the chapter covers both goods and services) seem to have a lower effect, which might however be biased because these provisions are likely to trigger the adoption of other ones. Only the six provisions with largest coefficients have a qualitatively larger effect than in the baseline estimates, where all government provisions are bunched together (see Table 1).

Figure A4 shows the same results for services. Almost all provisions taken individually contribute significantly to cross-border government procurement of services. As for goods, provisions on the disclosure of information, the availability of electronic auctions and the absence of phase ins for developing countries are among those with the largest impact. The rest of provisions have however similar effects, thus suggesting that it is difficult to disentangle the contribution of each provision.

We then adopt a more disciplined approach where we group provisions sharing similar characteristics. The results of the provision-specific regressions suggest that initiatives aimed at enhancing transparency and making procedures more accessible have the highest trade impact. A common trait of these provisions is that, while included in preferential trade agreements, they do not discriminate against non-members - they have a public good component and hence non-member countries cannot be excluded from its use. For instance, firms from non-member countries can access new and more detailed information and statistics about procurement contracts that governments make available as a result of provisions in TAs. To identify the distinctive impact of these provisions, we construct a variable that captures the extent of importers' "unilateral" liberalization - i.e., liberalization in areas likely to benefit both trade agreement member countries as well as non-members. This variable is equal to the importer's share of provisions in government procurement areas related to transparency and procedural disciplines ever included in any of its trade agreements. $^{26}$

The variable is unilateral as it only varies across importers and over time. To estimate its impact in a gravity framework, we follow recent work by Heid et al. (2021); Piermartini and Yotov (2016); Beverelli et al. (2018) and add to our baseline specification (eq (10)) an interaction between the unilateral provision variable and the same-country dummy. ${ }^{27}$

\footnotetext{
${ }^{26}$ These areas include requirements that information on the procurement laws and regulations is published and publicly available and the promotion of electronic auctions. The questions that form the DTA indicator variables on the content of TAs in government procurement cover eight areas: overview, non-discrimination, coverage, procedural disciplines, transparency, dispute settlement, and new issues.

${ }^{27}$ Sellner (2019) finds that this approach to identify the effects of non-discriminatory trade policies outperforms other methods such as a two-step estimator where estimates of the importer-year fixed effects
} 
As noted by these papers, crucial assumptions for identification are that the trade policy measure (i) does not discriminate across trading partners; and (ii) it does not affect domestic trade. Assumption (ii) might be violated in our setting - domestic firms might well benefit from, e.g., the availability of information on upcoming contracts or more transparent procedures -, thus affecting the significance and the sign of the coefficient on the interaction between the unilateral provision variable and the same-country dummy. We interpret this coefficient as indicating the extent to which deep commitments in government procurement affect domestic relative to international trade (see also Anderson et al. (2018) for a similar interpretation in a comparable exercise).

Tables 3 and 4 present the results for goods and services, respectively. For goods, the estimates suggest that adopting non-discriminatory measures has a null or even positive effect on domestic vs. cross-border government procurement. In particular, the coefficient on the unilateral depth variable interacted with the same-country dummy turns positive in column (3) of Table 3, where we control for the influence of GDP and GDP per capita of the importer (as proxies for country size and economic development) on the border effect. This seemingly surprising result is confirmed in column (5), where we include interactions with a measure of the quality of institutions (the average across the six categories of the World Bank's World Governance Indicators (WGI) database, which is found to decrease the border effect, consistent with the evidence from Beverelli et al. (2018)), and with other TA variables that can have non-discriminatory effect - the EU and GPA dummies equal one if the importer is a member of these TAs. The positive and significant interaction effect found also for trade in private markets, where unilateral depth in procurement provisions should not matter, casts doubts on the reliability of these findings. All in all, the results indicate that domestic firms might take advantage of more transparent procedures and open data on government procurement in goods, a the expenses of foreign firms.

Different than for goods, results in services, where the border effect is found to be significantly larger in public than private markets (see columns (1) and (2) of Table 2), suggest that countries with deep provisions on government procurement are more open to international trade. The interaction effect in Table 4 is consistently negative and significant across specifications for public markets, and the effect becomes weaker as we control for size and economic development. As an indication that the unilateral depth measures captures policies relevant to government procurement in services, the interaction effect is in the baseline gravity equation would be regressed on the unilateral variable. 
not significant for private markets. We thus find that deep non-discriminatory provisions on government procurement in TAs have been instrumental in promoting cross-border procurement flows in services, where governments have been buying significantly more locally than firms.

An important result from Tables 3 and 4 is that the bilateral trade policy effects become much lower and lose significance as we control for the unilateral components of TAs. One explanation for this intriguing result is that part of the bilateral component of the TA variables is actually unilateral, and hence not identified. Another way to read the finding is that most of the trade effect documented in the baseline specifications is actually non-discriminatory. Importantly, this is the case also for the EU dummy, which was the trade policy variable with the strongest effect in Tables 1 and 2. The negative coefficient on the interaction between the same-country dummy and the EU indicator suggests that a substantial part of this effect comes from trade with both EU and non-EU countries.

Table 3: PPML Gravity estimates: unilateral depth in trade agreements. Goods

\begin{tabular}{|c|c|c|c|c|c|c|}
\hline & $\begin{array}{l}(1) \\
\text { Gov. }\end{array}$ & $\begin{array}{l}(2) \\
\text { Priv. }\end{array}$ & $\begin{array}{l}(3) \\
\text { Gov. }\end{array}$ & $\begin{array}{l}(4) \\
\text { Priv. }\end{array}$ & $\begin{array}{l}(5) \\
\text { Gov. }\end{array}$ & $\begin{array}{c}(6) \\
\text { Priv. }\end{array}$ \\
\hline $\mathrm{TA}$ & $\begin{array}{c}0.358^{* *} \\
(0.156)\end{array}$ & $\begin{array}{c}0.242^{* *} \\
(0.106)\end{array}$ & $\begin{array}{c}0.091 \\
(0.118)\end{array}$ & $\begin{array}{l}-0.015 \\
(0.078)\end{array}$ & $\begin{array}{c}0.079 \\
(0.125)\end{array}$ & $\begin{array}{c}0.009 \\
(0.076)\end{array}$ \\
\hline $\mathrm{TA} \mathrm{w} /$ procurement & $\begin{array}{c}0.133^{* *} \\
(0.053)\end{array}$ & $\begin{array}{c}0.119^{* *} \\
(0.046)\end{array}$ & $\begin{array}{c}0.082 \\
(0.057)\end{array}$ & $\begin{array}{c}0.037 \\
(0.061)\end{array}$ & $\begin{array}{c}0.067 \\
(0.057)\end{array}$ & $\begin{array}{c}0.020 \\
(0.062)\end{array}$ \\
\hline WTO GPA & $\begin{array}{c}-0.223^{* * *} \\
(0.068)\end{array}$ & $\begin{array}{c}-0.250^{* * *} \\
(0.070)\end{array}$ & $\begin{array}{c}-0.120^{*} \\
(0.061)\end{array}$ & $\begin{array}{c}-0.118^{*} \\
(0.071)\end{array}$ & $\begin{array}{c}0.022 \\
(0.069)\end{array}$ & $\begin{array}{c}0.010 \\
(0.090)\end{array}$ \\
\hline 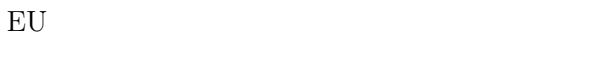 & $\begin{array}{c}0.472^{* * *} \\
(0.092)\end{array}$ & $\begin{array}{c}0.503^{* * *} \\
(0.059)\end{array}$ & $\begin{array}{c}0.314^{* * *} \\
(0.099)\end{array}$ & $\begin{array}{c}0.358^{* * *} \\
(0.073)\end{array}$ & $\begin{array}{c}-0.161 \\
(0.106)\end{array}$ & $\begin{array}{c}0.082 \\
(0.089)\end{array}$ \\
\hline Same country $\times$ Unilateral Procurement Depth & $\begin{array}{r}-0.158 \\
(0.136)\end{array}$ & $\begin{array}{c}-\mathbf{0 . 4 6 1} * * * \\
(0.117)\end{array}$ & $\begin{array}{c}\mathbf{0 . 5 3 7} * * * \\
(0.095)\end{array}$ & $\begin{array}{c}\mathbf{0 . 1 9 2}^{* *} \\
(0.092)\end{array}$ & $\begin{array}{c}\mathbf{0 . 6 2 7} * * * \\
(0.116)\end{array}$ & $\begin{array}{c}\mathbf{0 . 2 0 7 * *} \\
(0.086)\end{array}$ \\
\hline Same country $\times \operatorname{Ln}($ GDP $)$ & & & $\begin{array}{l}0.774^{*} \\
(0.440)\end{array}$ & $\begin{array}{c}0.569^{* *} \\
(0.279)\end{array}$ & $\begin{array}{c}0.094 \\
(0.456)\end{array}$ & $\begin{array}{c}0.704^{* *} \\
(0.305)\end{array}$ \\
\hline Same country $\times \operatorname{Ln}($ GPDpc $)$ & & & $\begin{array}{c}-1.464^{* * *} \\
(0.488)\end{array}$ & $\begin{array}{c}-1.129 * * * \\
(0.290)\end{array}$ & $\begin{array}{c}-0.707 \\
(0.504)\end{array}$ & $\begin{array}{c}-1.198^{* * *} \\
(0.318)\end{array}$ \\
\hline Same country $\times$ Institutions & & & & & $\begin{array}{c}-\mathbf{0 . 3 6 8 * * *} \\
(0.130)\end{array}$ & $\begin{array}{c}\mathbf{0 . 0 0 6} \\
(0.100)\end{array}$ \\
\hline Same country $\times$ EU (importer) & & & & & $\begin{array}{c}-1.112^{* * *} \\
(0.162)\end{array}$ & $\begin{array}{c}-\mathbf{0 . 5 9 0 * * *} \\
(0.178)\end{array}$ \\
\hline Same country $\times$ GPA (importer) & & & & & $\begin{array}{c}0.468^{* * *} \\
(0.138)\end{array}$ & $\begin{array}{c}0.414^{* * *} \\
(0.160)\end{array}$ \\
\hline Obs & 23,064 & 23,064 & 23,064 & 23,064 & 19,220 & 19,220 \\
\hline
\end{tabular}

Note: All regressions include importer-year, exporter-year and country-pair fixed effects. Data are for the years 1995, 1999, 2003, 2007, 2011 and 2015. Coefficients in bold are statistically different between the 'Gov.' and 'Priv.' regressions. Robust standard errors clustered at the country-pair level are in parentheses. Significant at: ${ }^{*} 10 \%,{ }^{* *} 5 \%,{ }^{* * *} 1 \%$ level. 
Table 4: PPML Gravity estimates: unilateral depth in trade agreements. Services

\begin{tabular}{|c|c|c|c|c|c|c|}
\hline & $\begin{array}{l}(1) \\
\text { Gov. }\end{array}$ & $\begin{array}{l}(2) \\
\text { Priv. }\end{array}$ & $\begin{array}{l}(3) \\
\text { Gov. }\end{array}$ & $\begin{array}{l}(4) \\
\text { Priv. }\end{array}$ & $\begin{array}{l}(5) \\
\text { Gov. }\end{array}$ & $\begin{array}{c}(6) \\
\text { Priv. }\end{array}$ \\
\hline $\mathrm{TA}$ & $\begin{array}{c}\mathbf{0 . 0 2 6} \\
(0.105)\end{array}$ & $\begin{array}{c}-\mathbf{0 . 2 1 4} \\
(0.101)\end{array}$ & $\begin{array}{c}-0.365^{* * *} \\
(0.105)\end{array}$ & $\begin{array}{c}-0.300^{* * *} \\
(0.092)\end{array}$ & $\begin{array}{c}-0.319^{* * *} \\
(0.101)\end{array}$ & $\begin{array}{c}-0.261^{* * *} \\
(0.084)\end{array}$ \\
\hline $\mathrm{TA} \mathrm{w} /$ procurement & $\begin{array}{l}-0.001 \\
(0.062)\end{array}$ & $\begin{array}{c}0.026 \\
(0.051)\end{array}$ & $\begin{array}{l}-0.083 \\
(0.068)\end{array}$ & $\begin{array}{l}-0.007 \\
(0.054)\end{array}$ & $\begin{array}{c}-0.107^{*} \\
(0.063)\end{array}$ & $\begin{array}{l}-0.023 \\
(0.050)\end{array}$ \\
\hline WTO GPA & $\begin{array}{c}-0.257 * * * \\
(0.087)\end{array}$ & $\begin{array}{c}\mathbf{0 . 0 3 1} \\
(0.066)\end{array}$ & $\begin{array}{l}-0.082 \\
(0.067)\end{array}$ & $\begin{array}{c}0.048 \\
(0.068)\end{array}$ & $\begin{array}{c}0.364^{* * *} \\
(0.090)\end{array}$ & $\begin{array}{c}0.266^{* * *} \\
(0.076)\end{array}$ \\
\hline $\mathrm{EU}$ & $\begin{array}{c}0.431^{* * *} \\
(0.095)\end{array}$ & $\begin{array}{c}0.332^{* * *} \\
(0.068)\end{array}$ & $\begin{array}{c}0.489^{* * *} \\
(0.090)\end{array}$ & $\begin{array}{c}0.434^{* * *} \\
(0.070)\end{array}$ & $\begin{array}{c}0.127 \\
(0.106)\end{array}$ & $\begin{array}{c}0.078 \\
(0.086)\end{array}$ \\
\hline Same country $\times$ Unilateral Procurement Depth & $\begin{array}{c}-1.492^{* * *} \\
(0.188)\end{array}$ & $\begin{array}{l}-0.028 \\
(0.115)\end{array}$ & $\begin{array}{c}-0.277^{* *} \\
(0.128)\end{array}$ & $\begin{array}{c}\mathbf{0 . 2 3 6}^{*} \\
(0.127)\end{array}$ & $\begin{array}{c}-\mathbf{0 . 2 9 5 * * *} \\
(0.106)\end{array}$ & $\begin{array}{l}\mathbf{0 . 1 5 0} \\
(0.119)\end{array}$ \\
\hline Same country $\times \operatorname{Ln}($ GDP $)$ & & & $\begin{array}{c}-1.395^{* * *} \\
(0.404)\end{array}$ & $\begin{array}{c}-1.102^{* * *} \\
(0.283)\end{array}$ & $\begin{array}{c}-1.664^{* * *} \\
(0.426)\end{array}$ & $\begin{array}{c}-1.197^{* * *} \\
(0.302)\end{array}$ \\
\hline Same country $\times \operatorname{Ln}($ GDPpc $)$ & & & $\begin{array}{l}0.789^{*} \\
(0.410)\end{array}$ & $\begin{array}{c}1.085^{* * *} \\
(0.309)\end{array}$ & $\begin{array}{l}1.102^{* *} \\
(0.434)\end{array}$ & $\begin{array}{c}1.229^{* * *} \\
(0.330)\end{array}$ \\
\hline Same country $\times$ Institutions & & & & & $\begin{array}{l}0.064 \\
(0.136)\end{array}$ & $\begin{array}{l}-0.168 \\
(0.115)\end{array}$ \\
\hline Same country $\times$ EU (importer) & & & & & $\begin{array}{c}-0.991^{* * *} \\
(0.202)\end{array}$ & $\begin{array}{c}-0.933^{* * *} \\
(0.166)\end{array}$ \\
\hline Same country $\times$ GPA (importer) & & & & & $\begin{array}{c}1.141^{* * *} \\
(0.159)\end{array}$ & $\begin{array}{c}\mathbf{0 . 7 7 9} * * * \\
(0.120)\end{array}$ \\
\hline Obs & 23,064 & 23,064 & 23,064 & 23,064 & 19,220 & 19,220 \\
\hline
\end{tabular}

Note: All regressions include importer-year, exporter-year and country-pair fixed effects. Data are for the years 1995, 1999, 2003, 2007, 2011 and 2015. Coefficients in bold are statistically different between the 'Gov.' and 'Priv.' regressions. Robust standard errors clustered at the country-pair level are in parentheses. Significant at: *10\%, **5\%, ***1\% level.

\subsection{Constructed Home Bias}

As the estimates of the border effect in Tables 1 and 2 suggest, government procurement is mostly local in spite of the liberalizing effects of trade agreements, especially in services. The border effect however provides only a partial measure of home bias since it does not take into account the effects of (changes in) trade barriers in other countries - in a gravity model, these influences play out through the multilateral resistance terms (see eq (2)). To overcome this drawback, we estimate the Constructed Home Bias (CHB) index proposed by Anderson and Yotov (2010b) for government procurement and for private markets. The CHB measures how much trade frictions around the world interact in shifting up domestic trade relative to what would be observed in a counterfactual world without trade barriers, holding constant overall sales and expenditure. As such, it aims to capture the general equilibrium interactions of trade barriers (conditional on aggregate sales and expenditure) and hence goes beyond the 'partial equilibrium' view of local bias from the perspective of a single country. The index encompasses all types of trade frictions (both 'man-made' trade policies and structural barriers) and hence it cannot be interpreted as a measure of protectionism. 
Estimated CHB indexes in public and private markets are constructed as in eq (11) separately for goods and services. The fixed-effects specification of the trade cost function in eq (10) (whose estimates are reported in columns (9) and (10) of Tables 1 and 2) is used in the estimation as it controls for all time-invariant factors that can affect bilateral trade. ${ }^{28}$

We first address the question of whether home bias in government procurement is higher than in private markets. Perhaps not surprisingly, the answer is a strong (but not resounding) "Yes". Figure 4 shows scatter plots of the estimated CHB index in government procurement against the same index for private markets, for goods and services. We take logs of both variables in order to smooth out the visual effect of some extreme outlier. Governments are generally more home biased than firms in their purchasing strategies as most of the observations lie above the 45 degree lines. Government home bias is higher than the private one for 67 percent of the country-year observations in goods, and a similar 62 percent in services.

Figure 4: CHB indexes by sector

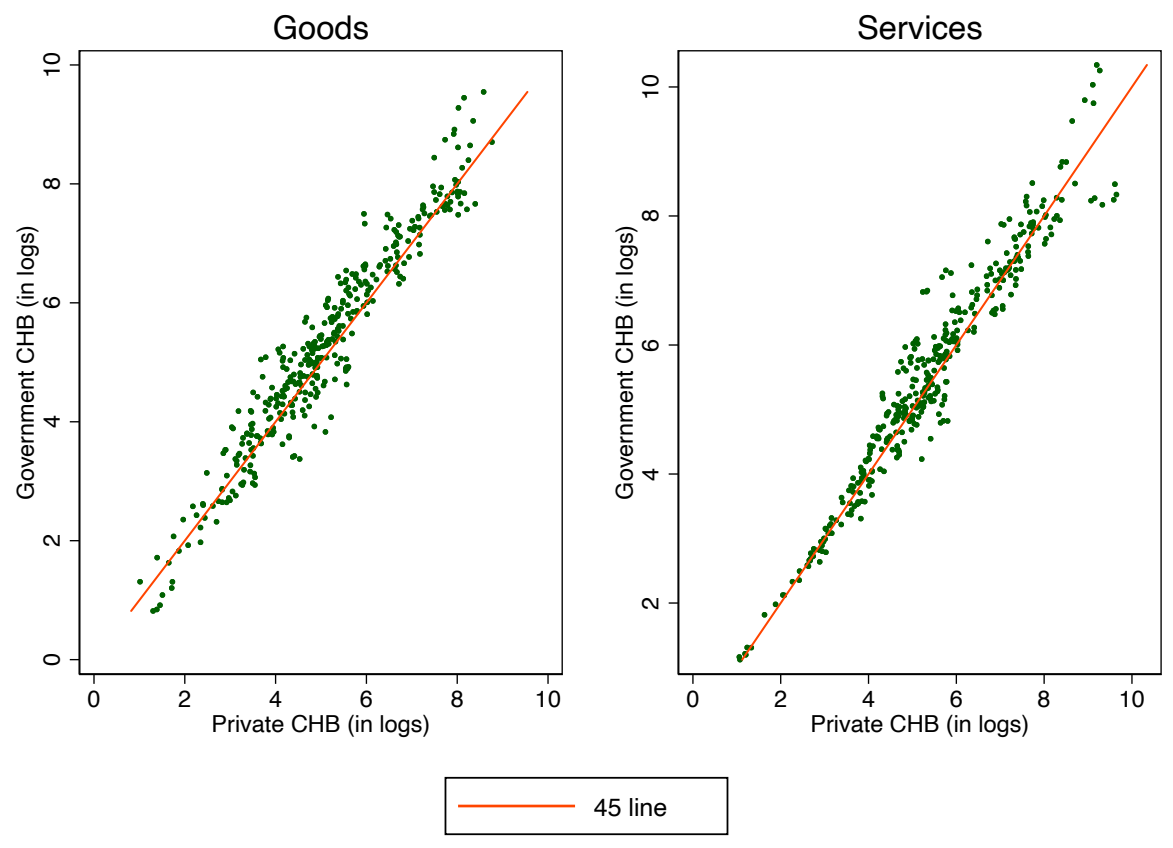

\footnotetext{
${ }^{28}$ Note that under that specification $t_{i i, t}^{k, s}=t_{j j, t}^{k, s} \forall i, j$, i.e. the border effect is equal across countries. Estimated trade costs worldwide affect the $\mathrm{CHB}$ via the multilateral resistance terms.
} 
To better appreciate differences across public and private markets as well as heterogeneity across countries, Table A2 in the Appendix reports the values of the estimated CHB indexes for goods. Home bias in government procurement is on average 35\% higher than home bias in private markets throughout the period. Looking at the average CHBs throughout the period, some differences emerge across countries. Similarly to what Anderson and Yotov (2010a) find for total trade, CHB is massive for small countries like Cambodia, Cyprus, and Brunei. This is because these countries naturally trade a lot with other countries and thus a high share of their income goes through bilateral trade barriers around the world, driving up the multilateral resistance terms. At the other end of the spectrum, CHBs are the lowest for large countries such as the U.S., Japan and China. While governments are more home biased than firms in their purchases of goods, their CHBs have declined more strongly. Only 22 out of 62 countries in our sample experienced an increase in government home bias, whereas CHBs in private markets went up for 32 countries. On average, home bias in government procurement of goods is 10 percent lower in 2015 relative to 1995. In private markets, the average home bias went up on average by 15 percent.

Table A3 in the Appendix reports estimated CHBs for services. As for goods, government procurement in services is more home biased than services purchases by private firms - on average, government CHBs are 18 percent higher than private CHBs. Between 1995 and 2015, home bias in government procurement of services went up in only 19 countries out of 62 in our sample - a share similar to that for private markets. The average CHB in government procurement is 11 percent lower in 2015 relative to 1995, a decrease that follows the one observed in goods. Unlike for goods, home bias in services went down on average also for private markets.

The estimated CHB indexes are then aggregated at the country level as weighted sum of the sectoral CHBs, where the weights are equal to their expenditure-times-sales shares (see Anderson et al. (2014)). Figure 5 plots the country-level government CHBs against the private ones. At the country level, government procurement markets are even more home biased than at the sectoral level. Government home bias is 70 percent higher than private home bias on average (government CHB is higher than private CHB in 71 percent of the country-year observations). This finding suggests that governments spend more (relative to private firms) on aggregate sectors that are more home biased. This composition effect contributes to the already important difference in home bias across government and private markets at the sector level. 
Figure 5: CHB indexes at the country level

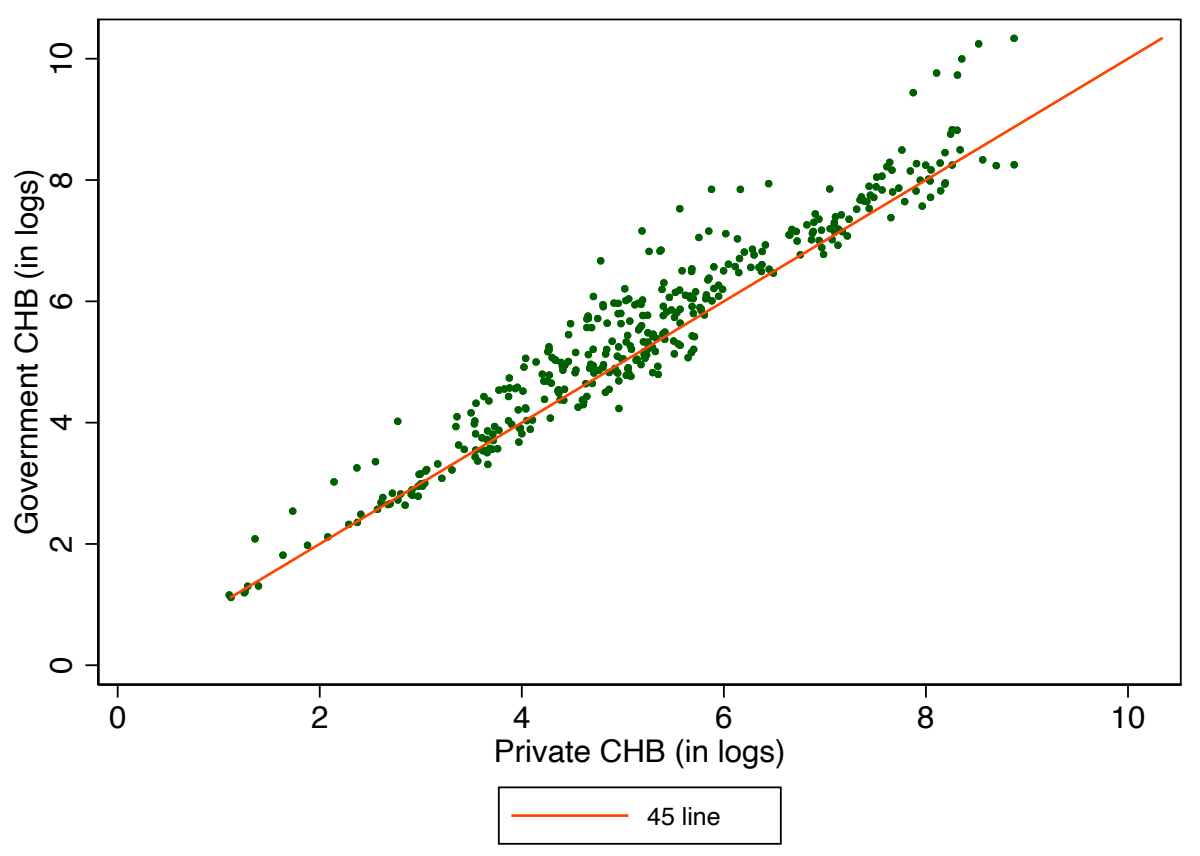

Table A10 in the Appendix reports the country-level CHB indexes for government procurement and private firms. The last two columns give the percent change in the CHB for each country in the sample. These numbers are showed graphically in Figure 6. At the aggregate level like at the sector level, we find that home bias in government procurement has gone down over time - the average change equals a 11 percent decrease (remarkably similar to the changes observed in the goods and in the services sectors), and more so than in private markets. Large variation however emerges across countries. The largest percent increases in government home bias are observed among developed economies - e.g., Japan, Germany and France. These countries have however also low levels of CHBs. Developing countries such as China, Vietnam and India report the largest drops in government home bias. Interestingly given the large trade effect of the EU single market (see Tables 1 and 2), most old EU member states experience an increase in home bias in government procurement during the sample period, whereas home bias went down in countries that entered the EU during the period (Croatia being the exception). 
Figure 5: Relative change in CHB indexes at the country level between 2015 and 1995

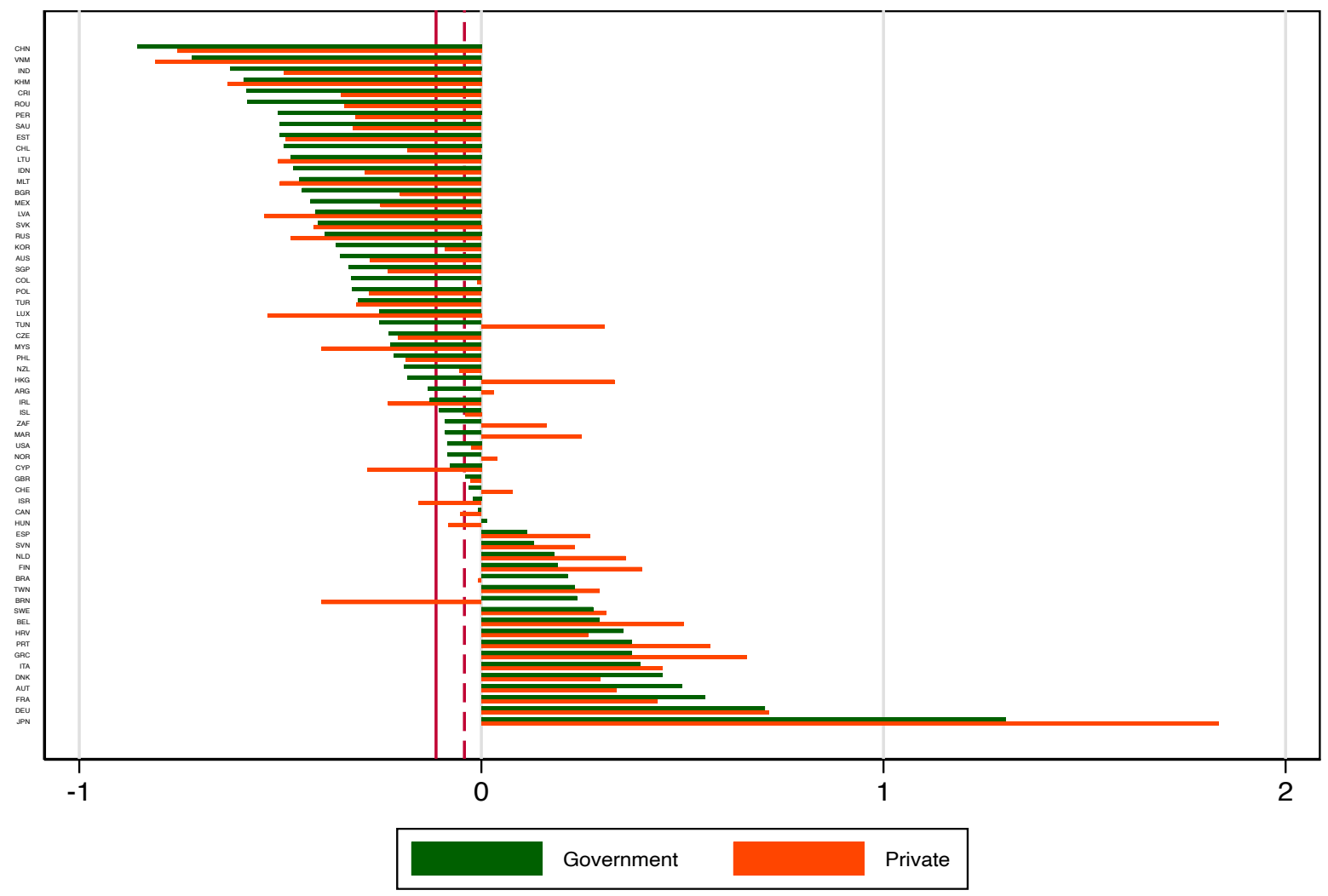

Overall, the analysis using the CHB indexes reveals that, while government procurement is significantly more home biased than private purchases, it has gone down faster. Important heterogeneity however emerges across countries. While the gravity results suggest that TAs have partly raised cross-border government procurement, the $\mathrm{CHB}$ values remind us that government procurement remains vastly home biased, even if the trends show a slow opening up to trade.

\section{Concluding remarks}

This paper estimates trade barriers in government procurement. In doing so, it analyses the role of trade agreements to see if and how much they have contributed to reduce those barriers.

Using new Inter-Country Input-Output (ICIO) tables from the TiVA database for 62 countries between 1995 and 2015, we obtain estimates of government purchases across 
sectors and countries of origin and use those in a standard gravity model. The estimates suggest that governments are significantly more local in their purchasing decisions than private firms. The border effect is large and significantly higher for public markets, especially in services. Yet, we find that trade agreements and the EU single market in particular have contributed to the opening up of government procurement, with the effect being robust in services. Non-discriminatory provisions specific to government procurement are driving the trade-creating effect of TAs in services, whereas the effects are overall weak in goods.

The estimates from the gravity model are then used to estimate indexes of home bias in government procurement and private markets. These measures capture the overall tendency to trade locally rather than internationally, and hence include also factors other than protectionist trade policies. Home bias is larger in government procurement than in private markets. Two mechanisms can account for this difference: (i) governments being on average more home biased than firms in purchases of both services and goods; and (ii) governments spending relatively more on sectors (goods and services) that are more home biased. We find that this difference is however shrinking over time: home bias in government procurement is declining faster than home bias in private markets.

Our results have implications for trade negotiations that touch upon government procurement issues. A strong result of our analysis is that national borders are relatively thicker in services, which absorb the lion share of public spending. Furthermore, we find that policy initiatives targeted to government procurement have been able to reduce trade barriers in services. These findings alone highlight potential complementarities between trade negotiations on services and government procurement. Serious and substantial service trade liberalization can have important liberalizing knock-on effects on government procurement procurement. 


\section{References}

Agnosteva, D.E., Anderson, J.E., Yotov, Y.V., 2019. Intra-national trade costs: Assaying regional frictions. European Economic Review 112, 32 - 50.

Anderson, J.E., 1979. A Theoretical Foundation for the Gravity Equation. American Economic Review 69(1), 106-16.

Anderson, J.E., 2011. The Gravity Model. Annual Review of Economics 3(1), 133-160.

Anderson, J.E., Borchert, I., Mattoo, A., Yotov, Y.V., 2018. Dark costs, missing data: Shedding some light on services trade. European Economic Review 105, 193-214.

Anderson, J.E., Milot, C.A., Yotov, Y.V., 2014. How Much Does Geography Deflect Services Trade? Canadian Answers. International Economic Review 55, 791-818.

Anderson, J.E., van Wincoop, E., 2003. Gravity with Gravitas: A Solution to the Border Puzzle. American Economic Review 93(1), 170-192.

Anderson, J.E., van Wincoop, E., 2004. Trade Costs. Journal of Economic Literature 42(3), $691-751$.

Anderson, J.E., Yotov, Y.V., 2010a. Specialization: Pro- and Anti-globalizing, 1990-2002. NBER Working Papers 16301.

Anderson, J.E., Yotov, Y.V., 2010b. The Changing Incidence of Geography. American Economic Review 100(5), 2157-86.

Anderson, R.D., Muller, A.C., Pelletier, P., 2017. Regional Trade Agreements and Procurement Rules. Facilitators or Hindrances?, in: Georgopulos, A.C., Hoekman, B., Mavroidis, P.C. (Eds.), The Internazionalization of Government Procurement Regulation.

Armington, P.S., 1969. A theory of demand for products distinguished by place of production. Staff Papers - International Monetary Fund 16(1), pp. 159-178.

Baier, S.L., Bergstrand, J.H., 2007. Do free trade agreements actually increase members' international trade? Journal of International Economics 71(1), 72-95.

Baldwin, R.E., 1970. Nontariff distortions of international trade. Brookings Institution, Washington DC. 
Bergstrand, J.H., Larch, M., Yotov, Y.V., 2015. Economic integration agreements, border effects, and distance elasticities in the gravity equation. European Economic Review 78, $307-327$.

Beverelli, C., Keck, A., Larch, M., Yotov, Y.V., 2018. Institutions, Trade and Development: A Quantitative Analysis. CESifo Working Paper Series 6920. CESifo.

Bosio, E., Djankov, S., Glaeser, E.L., Shleifer, A., 2020. Public Procurement in Law and Practice. Working Paper 27188. National Bureau of Economic Research.

Brulhart, M., Trionfetti, F., 2004. Public expenditure, international specialisation and agglomeration. European Economic Review 48(4), 851-881.

Chen, N., 2004. Intra-national versus international trade in the European Union: why do national borders matter? Journal of International Economics 63(1), 93-118.

Cole, M.T., Davies, R.B., Kaplan, T., 2017. Protection in government procurement auctions. Journal of International Economics 106(C), 134-142.

Costinot, A., Rodriguez-Clare, A., 2015. Chapter 4 - trade theory with numbers: Quantifying the consequences of globalization, Elsevier. volume 4 of Handbook of International Economics, pp. $197-261$.

Disdier, A.C., Head, K., 2008. The Puzzling Persistence of the Distance Effect on Bilateral Trade. The Review of Economics and Statistics 90(1), 37-48.

Dür, A., Baccini, L., Elsig, M., 2014. The design of international trade agreements: Introducing a new dataset. The Review of International Organizations 9(3), 353-375.

Eaton, J., Kortum, S., 2002. Technology, Geography, and Trade. Econometrica 70(5), 1741-1779.

Egger, P., Larch, M., Staub, K.E., Winkelmann, R., 2011. The Trade Effects of Endogenous Preferential Trade Agreements. American Economic Journal: Economic Policy 3(3), $113-43$.

Egger, P.H., Larch, M., Yotov, Y.V., 2020. Gravity-Model Estimation with Time-Interval Data: Revisiting the Impact of Free Trade Agreements. CESifo Working Paper Series 8553. 
Fajgelbaum, P., Khandelwal, A., 2016. Measuring the Unequal Gains from Trade. The Quarterly Journal of Economics 131(3), 1113-1180.

Fally, T., 2015. Structural gravity and fixed effects. Journal of International Economics $97(1), 76-85$.

Fronk, J., 2014. Do Procurement Agreements Increase Partners' Trade? Working Paper.

Gourdon, J., Messent, J., 2019. How Government Procurement Measures Can Affect Trade. Journal of World Trade 53(5), 679-757.

Head, K., Mayer, T., 2015. Chapter 3 - gravity equations: Workhorse,toolkit, and cookbook, in: Elhanan Helpman, K.R., Gopinath, G. (Eds.), Handbook of International Economics. Elsevier. volume 4, pp. $131-195$.

Heid, B., Larch, M., Yotov, Y., 2021. Estimating the Effects of Non-discriminatory Trade Policies within Structural Gravity Models. Canadian Journal of Economics Forthcoming.

Herz, B., Varela-Irimia, X.L., 2020. Border effects in European public procurement. Journal of Economic Geography 20(6), 1359-1405.

Kohl, T., Brakman, S., Garretsen, H., 2016. Do Trade Agreements Stimulate International Trade Differently? Evidence from 296 Trade Agreements. The World Economy 39(1), $97-131$.

Kutlina-Dimitrova, Z., Lakatos, C., 2014. Determinants of direct cross-border public procurement in EU member states. Review of World Economics 152.

Larch, M., Lechthaler, W., 2013. Buy National or Buy International? The optimal design of government spending in an open economy. International Review of Economics \& Finance $26,87-108$.

Mattoo, A., Mulabdic, A., Ruta, M., 2017. Trade Creation and Trade Diversion in Deep Agreements. The World Bank.

Mattoo, A., Rocha, N., Ruta, M., 2020. Handbook of Deep Trade Agreements. Number 34055 in World Bank Publications, The World Bank.

Mayer, T., Zignago, S., 2011. Notes on CEPII's distances measures: The GeoDist database. Working Papers 2011-25. CEPII research center. 
McAfee, R.P., McMillan, J., 1989. Government procurement and international trade. Journal of International Economics 26(3-4), 291-308.

McCallum, J., 1995. National Borders Matter: Canada-U.S. Regional Trade Patterns. American Economic Review 85(3), 615-23.

Messerlin, P., Mirodout, S., 2012. EU public procurement markets: How open are they. Policy brief. Groupe d'Economie Mondiale.

Miyagiwa, K., 1991. Oligopoly and Discriminatory Government Procurement Policy. The American Economic Review 81(5), pp. 1320-1328.

Novy, D., 2013. Gravity Redux: Measuring International Trade Costs With Panel Data. Economic Inquiry 51(1), 101-121.

OECD, 2013a. Government at glance 2013. Report - Directorate for Public Governance and Territorial Development, Organisation for Economic Cooperation and Development.

OECD, 2013b. Measuring trade in value added: An OECD-WTO joint initiative. TiVA database. Organisation for Economic Cooperation and Development (OECD).

Piermartini, R., Yotov, Y.V., 2016. Estimating trade policy effects with structural gravity. WTO Staff Working Papers ERSD-2016-10. World Trade Organization (WTO), Economic Research and Statistics Division.

Rickard, S., Kono, D., 2014. Think globally, buy locally: International agreements and government procurement. The Review of International Organizations 9(3), 333-352.

Riker, D., 2013. Government Consumption and Global Value Chains. Technical Report 2013-04A. Office of Economics Working Papers. U.S. International Trade Commission.

Sellner, R., 2019. Non-discriminatory Trade Policies in Panel Structural Gravity Models: Evidence from Monte Carlo Simulations. Review of International Economics 27(3), $854-887$.

Silva, J.M.C.S., Tenreyro, S., 2006. The Log of Gravity. The Review of Economics and Statistics 88(4), 641-658.

de Sousa, J., Mayer, T., Zignago, S., 2012. Market access in global and regional trade. Regional Science and Urban Economics 42(6), 1037-1052. 
The European Commission, 2017. Measurement of impact of cross-border penetration in public procurement. Report.

Timmer, M.P., 2012. The World Input-Output Database (WIOD): Contents, Sources and Methods. Technical Report. WIOD Working Paper Number 10.

Trionfetti, F., 2000. Discriminatory Public Procurement and International Trade. The World Economy 23(1), 57-76.

Trionfetti, F., 2001. Public Procurement, Market Integration, and Income Inequalities. Review of International Economics 9(1), 29-41. 


\section{Appendix}

Table A1: List of sectors.

\begin{tabular}{|c|c|c|c|}
\hline Aggregate sector & Sector & ISIC Rev $3(1995-2004)$ & ISIC Rev $4(2005-2015)$ \\
\hline \multirow{10}{*}{ Goods } & Agriculture, Forestry and Fishing & $01,02,03,04,05$ & $01,02,03$ \\
\hline & Mining & $10,11,12,13,14$ & $05,06,07,08,09$ \\
\hline & Food and Beverages & 15,16 & $10,11,12$ \\
\hline & Textile and Apparel & $17,18,19$ & $13,14,15$ \\
\hline & Wood, paper products and printing & $20,21,22$ & $16,17,18$ \\
\hline & Chemical products & $23,24,25,26$ & $19,20,21,22,23$ \\
\hline & Metals and metal products & 27,28 & 24,25 \\
\hline & Machinery and equipment & $29,30,31,32,33$ & $26,27,28$ \\
\hline & Transport equipment & 34,35 & 29,30 \\
\hline & Other manufacturing & 36,37 & $31,32,33$ \\
\hline \multirow{6}{*}{ Services } & Retail and hotel services & $50,51,52,55$ & $45,46,47,55,56$ \\
\hline & Transport and telecommunication services & $60,61,62,63,64$ & $\begin{array}{l}49,50,51,52, \\
53,58,59,60,61\end{array}$ \\
\hline & Finance and insurance & $65,66,67$ & $64,65,66$ \\
\hline & Real estate & 70,71 & 68 \\
\hline & Public administration, health and education & $\begin{array}{l}75,80,85,86,87, \\
88\end{array}$ & $\begin{array}{l}84,85,86,87,88,90 \\
91,92,93,94,95,96\end{array}$ \\
\hline & Other services & $72,73,74$ & $\begin{array}{l}62,63,69,70,71 \\
72,73,74,75,77 \\
78,79,80,81,82\end{array}$ \\
\hline
\end{tabular}

Note: The "Sector" column reports the sectoral aggregations that are used in the sector-level regressions (see Tables A6 and A7). The third and fourth columns reported the corresponding two-digit chapters of the ISIC Rev. 3 and ISIC Rev. 4 industrial classifications.

Figure A1: Services share of purchases in public and private markets. "Narrow" definition

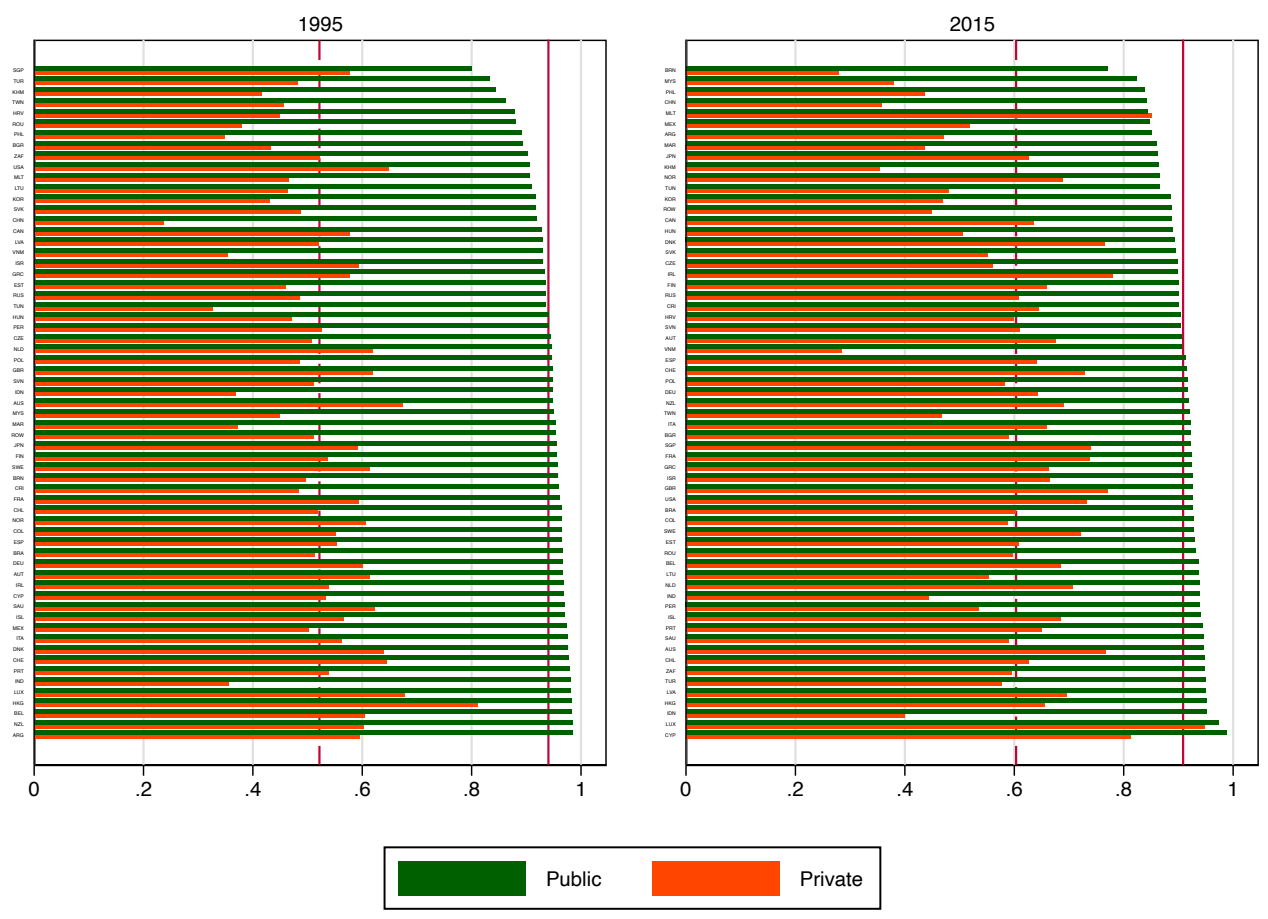

Note: Raw data are source from the TiVA database. Public procurement flows are computed using the "narrow" definition (see the main text for details). The vertical solid line indicates the average service share in public procurement across countries. The dashed line reports the same average for private markets. 
Figure A2: Government import penetration/ Private import ratio by country. "Narrow" definition.

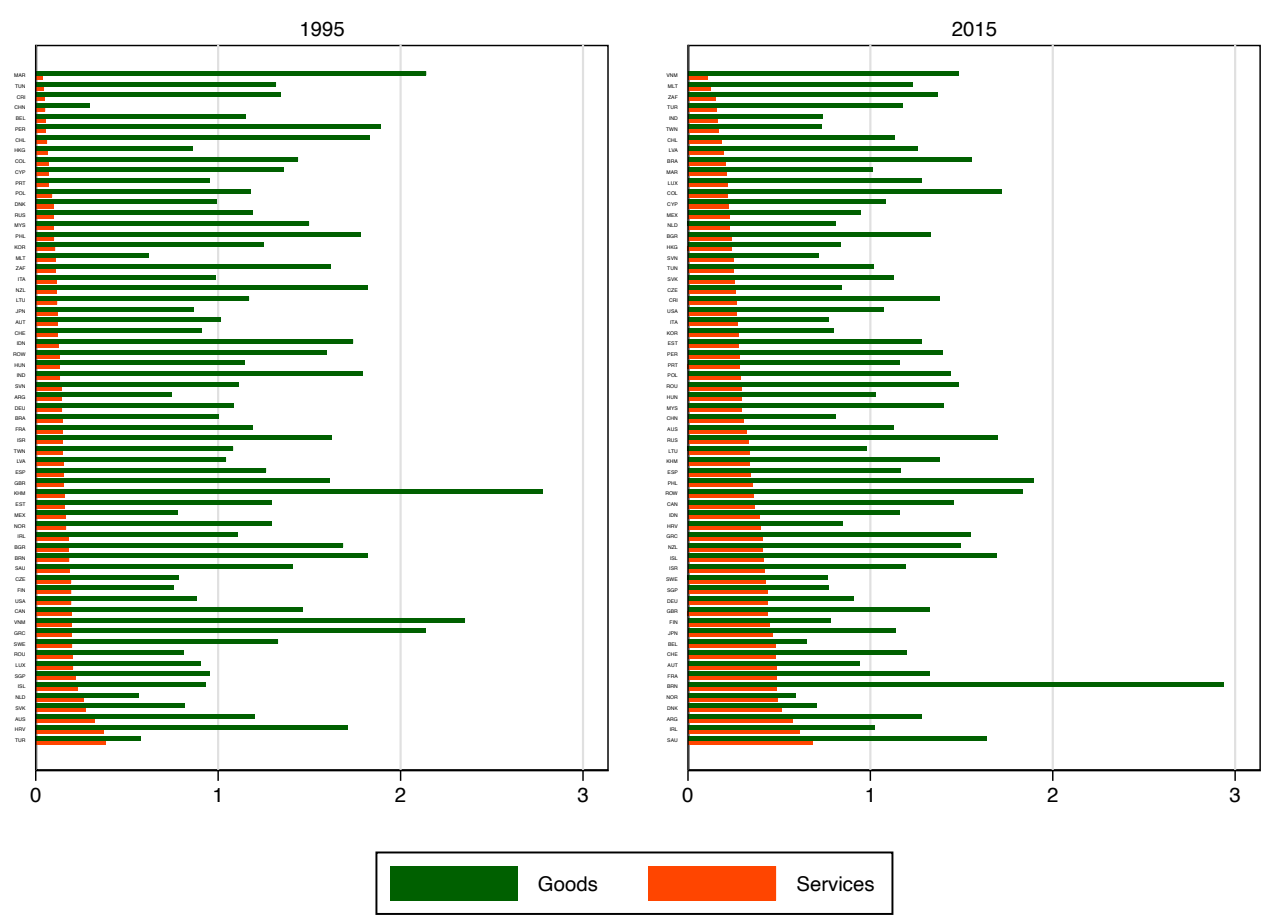

Note: Raw data are sourced from the TiVA database. Public procurement flows are computed using the "narrow" definition (see the main text for details). 
Table A2: PPML Gravity estimates, Goods, "narrow" definition.

\begin{tabular}{|c|c|c|c|c|c|c|c|c|c|c|}
\hline & $\begin{array}{l}(1) \\
\text { Gov. }\end{array}$ & $\begin{array}{l}(2) \\
\text { Priv. }\end{array}$ & $\begin{array}{l}(3) \\
\text { Gov. }\end{array}$ & $\begin{array}{l}(4) \\
\text { Priv. }\end{array}$ & $\begin{array}{l}(5) \\
\text { Gov. }\end{array}$ & $\begin{array}{l}(6) \\
\text { Priv. }\end{array}$ & $\begin{array}{l}(7) \\
\text { Gov. }\end{array}$ & $\begin{array}{l}(8) \\
\text { Priv. }\end{array}$ & $\begin{array}{l}\text { (9) } \\
\text { Gov. }\end{array}$ & $\begin{array}{l}(10) \\
\text { Priv. }\end{array}$ \\
\hline Same country & $\begin{array}{c}3.439^{* * *} \\
(0.176)\end{array}$ & $\begin{array}{c}3.147^{* * *} \\
(0.187)\end{array}$ & & & & & & & & \\
\hline Contiguity & $\begin{array}{c}0.239^{* *} \\
(0.121)\end{array}$ & $\begin{array}{c}0.280^{* *} \\
(0.126)\end{array}$ & & & & & & & & \\
\hline Common language & $\begin{array}{c}0.352^{\text {**** }} \\
(0.108)\end{array}$ & $\begin{array}{c}0.277^{* * *} \\
(0.101)\end{array}$ & & & & & & & & \\
\hline Colony & $\begin{array}{c}0.290^{*} \\
(0.159)\end{array}$ & $\begin{array}{c}0.385 \\
(0.240)\end{array}$ & & & & & & & & \\
\hline Ln Distance & $\begin{array}{c}-\mathbf{0 . 6 5 1} \text { *** } \\
(0.049)\end{array}$ & $\begin{array}{c}-\mathbf{0 . 8 1 2} \text { *** } \\
(0.051)\end{array}$ & & & & & & & & \\
\hline Common legal origin & $\begin{array}{l}-0.002 \\
(0.083)\end{array}$ & $\begin{array}{c}0.041 \\
(0.082)\end{array}$ & & & & & & & & \\
\hline TA & $\begin{array}{l}-0.086 \\
(0.120)\end{array}$ & $\begin{array}{c}0.038 \\
(0.135)\end{array}$ & $\begin{array}{c}0.214^{* * *} \\
(0.042)\end{array}$ & $\begin{array}{c}0.294^{* * *} \\
(0.037)\end{array}$ & $\begin{array}{c}0.384^{* *} \\
(0.152)\end{array}$ & $\begin{array}{c}0.318^{* * *} \\
(0.098)\end{array}$ & $\begin{array}{c}0.385^{* *} \\
(0.152)\end{array}$ & $\begin{array}{c}0.318^{* * *} \\
(0.098)\end{array}$ & $\begin{array}{c}0.381^{* *} \\
(0.152)\end{array}$ & $\begin{array}{c}0.314^{* * * *} \\
(0.098)\end{array}$ \\
\hline TA w/ procurement & $\begin{array}{c}0.168 \\
(0.106)\end{array}$ & $\begin{array}{c}0.269^{* *} \\
(0.121)\end{array}$ & & & $\begin{array}{c}\mathbf{0 . 1 9 1} * * * \\
(0.043)\end{array}$ & $\begin{array}{c}\mathbf{0 . 2 8 8} \\
(0.038 * *\end{array}$ & $\begin{array}{c}0.212^{* * *} \\
(0.045)\end{array}$ & $\begin{array}{c}0.274^{* * *} \\
(0.041)\end{array}$ & $\begin{array}{c}0.163^{* * *} \\
(0.048)\end{array}$ & $\begin{array}{c}0.218^{* * *} \\
(0.039)\end{array}$ \\
\hline WTO GPA & $\begin{array}{c}0.596^{* * *} \\
(0.119)\end{array}$ & $\begin{array}{c}0.362^{* * * *} \\
(0.124)\end{array}$ & & & & & $\begin{array}{c}-0.071 \\
(0.055)\end{array}$ & $\begin{array}{c}0.044 \\
(0.054)\end{array}$ & $\begin{array}{c}-0.171^{* * * *} \\
(0.052)\end{array}$ & $\begin{array}{l}-0.088 \\
(0.063)\end{array}$ \\
\hline EU & $\begin{array}{c}0.064 \\
(0.118)\end{array}$ & $\begin{array}{c}0.126 \\
(0.105)\end{array}$ & & & & & & & $\begin{array}{c}0.499^{* * *} \\
(0.090)\end{array}$ & $\begin{array}{c}0.575^{* * *} \\
(0.069)\end{array}$ \\
\hline Obs & 23,064 & 23,064 & 23,064 & 23,064 & 23,064 & 23,064 & 23,064 & 23,064 & 23,064 & 23,064 \\
\hline
\end{tabular}

Note: All regressions include importer-year and exporter-year fixed effects. Columns (3) to (10) include also country-pair fixed effects. In columns (3) and (4), the $T A$ dummy equals one if the two countries in the pair belong to the same TA (with or without provisions on government procurement). Data are for the years 1995, 1999, 2003, 2007, 2011 and 2015. Coefficients in bold are statistically different between the 'Gov.' and 'Priv.' regressions. Robust standard errors clustered at the country-pair level are in parentheses. Significant at: ${ }^{*} 10 \%, * * 5 \%, * * * 1 \%$ level.

Table A3: PPML Gravity estimates, Services, "narrow" definition.

\begin{tabular}{|c|c|c|c|c|c|c|c|c|c|c|}
\hline & $\begin{array}{l}(1) \\
\text { Gov. }\end{array}$ & $\begin{array}{l}(2) \\
\text { Priv. }\end{array}$ & $\begin{array}{l}(3) \\
\text { Gov. }\end{array}$ & $\begin{array}{l}(4) \\
\text { Priv. }\end{array}$ & $\begin{array}{l}(5) \\
\text { Gov. }\end{array}$ & $\begin{array}{c}(6) \\
\text { Priv. }\end{array}$ & $\begin{array}{l}(7) \\
\text { Gov. }\end{array}$ & $\begin{array}{c}(8) \\
\text { Priv. }\end{array}$ & $\begin{array}{l}\text { (9) } \\
\text { Gov. }\end{array}$ & $\begin{array}{l}(10) \\
\text { Priv. }\end{array}$ \\
\hline Same country & $\begin{array}{c}\mathbf{7 . 3 4 1} * * * \\
(0.173)\end{array}$ & $\begin{array}{c}5.805^{* * *} \\
(0.195)\end{array}$ & & & & & & & & \\
\hline Contiguity & $\begin{array}{c}0.233^{* *} \\
(0.103)\end{array}$ & $\begin{array}{c}0.390^{* * * *} \\
(0.128)\end{array}$ & & & & & & & & \\
\hline Common language & $\begin{array}{c}0.612^{* * * *} \\
(0.096)\end{array}$ & $\begin{array}{c}0.609^{* * *} \\
(0.102)\end{array}$ & & & & & & & & \\
\hline Colony & $\begin{array}{c}0.706^{* * *} \\
(0.182)\end{array}$ & $\begin{array}{c}0.890^{* * * *} \\
(0.180)\end{array}$ & & & & & & & & \\
\hline Ln Distance & $\begin{array}{c}-0.420^{* * *} \\
(0.051)\end{array}$ & $\begin{array}{c}-0.382^{* * *} \\
(0.057)\end{array}$ & & & & & & & & \\
\hline Common legal origin & $\begin{array}{c}0.065 \\
(0.067)\end{array}$ & $\begin{array}{c}0.068 \\
(0.080)\end{array}$ & & & & & & & & \\
\hline TA & $\begin{array}{c}0.435^{* * * *} \\
(0.156)\end{array}$ & $\begin{array}{c}0.399^{* * * *} \\
(0.144)\end{array}$ & $\begin{array}{c}\mathbf{0 . 6 8 4} \boldsymbol{* * *} * \\
(0.069)\end{array}$ & $\begin{array}{c}0.082^{* *} \\
(0.040)\end{array}$ & $\begin{array}{c}\mathbf{0 . 4 8 2} \boldsymbol{* * *} \\
(0.085)\end{array}$ & $\begin{array}{c}-\mathbf{0 . 2 0 8} \\
(0.099)\end{array}$ & $\begin{array}{c}\mathbf{0 . 4 8 1} \boldsymbol{* * *} * \\
(0.083)\end{array}$ & $\begin{array}{c}-\mathbf{0 . 2 0 8} * * \\
(0.099)\end{array}$ & $\begin{array}{c}\mathbf{0 . 4 7 8} * * * \\
(0.083)\end{array}$ & $\begin{array}{c}-\mathbf{0 . 2 1 0} * * \\
(0.099)\end{array}$ \\
\hline $\mathrm{TA} \mathrm{w} /$ procurement & $\begin{array}{c}0.001 \\
(0.106)\end{array}$ & $\begin{array}{l}-0.078 \\
(0.121)\end{array}$ & & & $\begin{array}{c}\mathbf{0 . 7 1 0 * * *} \\
(0.079)\end{array}$ & $\begin{array}{c}\mathbf{0 . 1 4 2} \text { **** } \\
(0.040)\end{array}$ & $\begin{array}{c}\mathbf{0 . 4 6 5 * * *} \\
(0.067)\end{array}$ & $\begin{array}{c}\mathbf{0 . 0 9 1} * * \\
(0.043)\end{array}$ & $\begin{array}{c}\mathbf{0 . 4 0 2} * * * \\
(0.070)\end{array}$ & $\begin{array}{c}\mathbf{0 . 0 3 0} \\
(0.044)\end{array}$ \\
\hline WTO GPA & $\begin{array}{c}0.972^{* * *} \\
(0.101)\end{array}$ & $\begin{array}{c}0.738^{* * *} \\
(0.106)\end{array}$ & & & & & $\begin{array}{c}\mathbf{0 . 5 6 0} \\
(0.062)\end{array}$ & $\begin{array}{c}\mathbf{0 . 1 2 7} \text { ** } \\
(0.049)\end{array}$ & $\begin{array}{c}\mathbf{0 . 4 2 7} * * * \\
(0.058)\end{array}$ & $\begin{array}{c}\mathbf{0 . 0 3 5} \\
(0.052)\end{array}$ \\
\hline EU & $\begin{array}{c}0.170 \\
(0.117)\end{array}$ & $\begin{array}{c}0.103 \\
(0.116)\end{array}$ & & & & & & & $\begin{array}{c}\mathbf{0 . 7 5 1} \mathbf{1}^{* * *} \\
(0.096)\end{array}$ & $\begin{array}{c}\mathbf{0 . 3 3 5} \text { *** } \\
(0.065)\end{array}$ \\
\hline Obs & 23,064 & 23,064 & 23,064 & 23,064 & 23,064 & 23,064 & 23,064 & 23,064 & 23,064 & 23,064 \\
\hline
\end{tabular}

Note: All regressions include importer-year and exporter-year fixed effects. Columns (3) to (10) include also country-pair fixed effects. In columns (3) and (4), the $T A$ dummy equals one if the two countries in the pair belong to the same TA (with or without provisions on government procurement). Data are for the years 1995, 1999, 2003, 2007, 2011 and 2015. Coefficients in bold are statistically different between the 'Gov.' and 'Priv.' regressions. Robust standard errors clustered at the country-pair level are in parentheses. Significant at: ${ }^{*} 10 \%, * * 5 \%, * * * 1 \%$ level. 
Table A4: PPML Gravity estimates, Goods, full sample.

\begin{tabular}{|c|c|c|c|c|c|c|c|c|c|c|}
\hline & $\begin{array}{l}(1) \\
\text { Gov. }\end{array}$ & $\begin{array}{l}(2) \\
\text { Priv. }\end{array}$ & $\begin{array}{l}(3) \\
\text { Gov. }\end{array}$ & $\begin{array}{l}(4) \\
\text { Priv. }\end{array}$ & $\begin{array}{l}(5) \\
\text { Gov. }\end{array}$ & $\begin{array}{c}(6) \\
\text { Priv. }\end{array}$ & $\begin{array}{l}(7) \\
\text { Gov. }\end{array}$ & $\begin{array}{c}(8) \\
\text { Priv. }\end{array}$ & $\begin{array}{l}\text { (9) } \\
\text { Gov. }\end{array}$ & $\begin{array}{l}(10) \\
\text { Priv. }\end{array}$ \\
\hline Same country & $\begin{array}{c}3.460^{* * *} \\
(0.166)\end{array}$ & $\begin{array}{c}3.128^{* * *} \\
(0.187)\end{array}$ & & & & & & & & \\
\hline Contiguity & $\begin{array}{c}0.238^{* *} \\
(0.120)\end{array}$ & $\begin{array}{c}0.290^{* *} \\
(0.127)\end{array}$ & & & & & & & & \\
\hline Common language & $\begin{array}{c}0.360^{* * *} \\
(0.110)\end{array}$ & $\begin{array}{c}0.287^{* * *} \\
(0.101)\end{array}$ & & & & & & & & \\
\hline Colony & $\begin{array}{c}0.323^{* *} \\
(0.161)\end{array}$ & $\begin{array}{l}0.396^{*} \\
(0.236)\end{array}$ & & & & & & & & \\
\hline Ln Distance & $\begin{array}{c}-\mathbf{0 . 6 4 6} \\
(0.048)\end{array}$ & $\begin{array}{c}-\mathbf{0 . 8 1 9} * * * \\
(0.052)\end{array}$ & & & & & & & & \\
\hline Common legal origin & $\begin{array}{l}-0.003 \\
(0.081)\end{array}$ & $\begin{array}{c}0.038 \\
(0.081)\end{array}$ & & & & & & & & \\
\hline TA & $\begin{array}{l}-0.095 \\
(0.118)\end{array}$ & $\begin{array}{c}0.037 \\
(0.136)\end{array}$ & $\begin{array}{c}\mathbf{0 . 1 6 7 * * *} \\
(0.042)\end{array}$ & $\begin{array}{c}\mathbf{0 . 2 6 8} * * * \\
(0.037)\end{array}$ & $\begin{array}{c}0.329 * * \\
(0.130)\end{array}$ & $\begin{array}{c}0.275^{* * *} \\
(0.088)\end{array}$ & $\begin{array}{c}0.330^{* *} \\
(0.130)\end{array}$ & $\begin{array}{c}0.275^{* * *} \\
(0.088)\end{array}$ & $\begin{array}{c}0.326^{* *} \\
(0.130)\end{array}$ & $\begin{array}{c}0.272^{* * * *} \\
(0.088)\end{array}$ \\
\hline $\mathrm{TA} \mathrm{w} /$ procurement & $\begin{array}{c}0.163 \\
(0.107)\end{array}$ & $\begin{array}{l}0.227^{*} \\
(0.126)\end{array}$ & & & $\begin{array}{c}\mathbf{0 . 1 4 2} \\
(0.04 * * \\
\end{array}$ & $\begin{array}{c}\mathbf{0 . 2 6 6} \text { **** } \\
(0.039)\end{array}$ & $\begin{array}{c}0.156^{* * *} * \\
(0.047)\end{array}$ & $\begin{array}{c}0.258^{* * *} \\
(0.046)\end{array}$ & $\begin{array}{c}0.102^{* *} \\
(0.049)\end{array}$ & $\begin{array}{c}0.190^{* * *} \\
(0.044)\end{array}$ \\
\hline WTO GPA & $\begin{array}{c}0.602^{* * *} \\
(0.116)\end{array}$ & $\begin{array}{c}0.378^{* * *} \\
(0.123)\end{array}$ & & & & & $\begin{array}{l}-0.051 \\
(0.062)\end{array}$ & $\begin{array}{l}0.024 \\
(0.062)\end{array}$ & $\begin{array}{c}-0.169^{* * *} \\
(0.058)\end{array}$ & $\begin{array}{c}-0.118^{*} \\
(0.068)\end{array}$ \\
\hline EU & $\begin{array}{c}0.079 \\
(0.118)\end{array}$ & $\begin{array}{c}0.083 \\
(0.105)\end{array}$ & & & & & & & $\begin{array}{c}0.467^{* * *} \\
(0.089)\end{array}$ & $\begin{array}{c}0.565^{* * *} \\
(0.073)\end{array}$ \\
\hline Obs & 80,724 & 80,724 & 80,724 & 80,724 & 80,724 & 80,724 & 80,724 & 80,724 & 80,724 & 80,724 \\
\hline
\end{tabular}

Note: All regressions include importer-year and exporter-year fixed effects. Columns (3) to (10) include also country-pair fixed effects. In columns (3) and (4), the $T A$ dummy equals one if the two countries in the pair belong to the same TA (with or without provisions on government procurement). Data are for all years between 1995 and 2015 . Coefficients in bold are statistically different between the 'Gov.' and 'Priv.' regressions. Robust standard errors clustered at the country-pair level are in parentheses. Significant at: ${ }^{*} 10 \%, * * 5 \%, * * * 1 \%$ level.

Table A5: PPML Gravity estimates, Services, full sample.

\begin{tabular}{|c|c|c|c|c|c|c|c|c|c|c|}
\hline & $\begin{array}{l}(1) \\
\text { Gov. }\end{array}$ & $\begin{array}{c}(2) \\
\text { Priv. }\end{array}$ & $\begin{array}{l}(3) \\
\text { Gov. }\end{array}$ & $\begin{array}{l}(4) \\
\text { Priv. }\end{array}$ & $\begin{array}{l}(5) \\
\text { Gov. }\end{array}$ & $\begin{array}{l}(6) \\
\text { Priv. }\end{array}$ & $\begin{array}{l}(7) \\
\text { Gov. }\end{array}$ & $\begin{array}{c}(8) \\
\text { Priv. }\end{array}$ & $\begin{array}{l}(9) \\
\text { Gov. }\end{array}$ & $\begin{array}{l}(10) \\
\text { Priv. }\end{array}$ \\
\hline Same country & $\begin{array}{c}6.977^{* * * *} \\
(0.181)\end{array}$ & $\begin{array}{c}\mathbf{5 . 7 8 1} * * * \\
(0.195)\end{array}$ & & & & & & & & \\
\hline Contiguity & $\begin{array}{l}0.190^{*} \\
(0.112)\end{array}$ & $\begin{array}{c}0.390^{* * *} * \\
(0.128)\end{array}$ & & & & & & & & \\
\hline Common language & $\begin{array}{c}0.636^{* * *} \\
(0.103)\end{array}$ & $\begin{array}{c}0.612^{* * *} \\
(0.102)\end{array}$ & & & & & & & & \\
\hline Colony & $\begin{array}{c}0.676^{* * *} \\
(0.180)\end{array}$ & $\begin{array}{c}0.888^{* * *} \\
(0.176)\end{array}$ & & & & & & & & \\
\hline Ln Distance & $\begin{array}{c}-0.455^{* * *} \\
(0.054)\end{array}$ & $\begin{array}{c}-0.391^{* * *} \\
(0.057)\end{array}$ & & & & & & & & \\
\hline Common legal origin & $\begin{array}{c}0.077 \\
(0.069)\end{array}$ & $\begin{array}{c}0.066 \\
(0.080)\end{array}$ & & & & & & & & \\
\hline TA & $\begin{array}{c}0.368^{* *} \\
(0.165)\end{array}$ & $\begin{array}{c}0.426^{* * *} \\
(0.151)\end{array}$ & $\begin{array}{c}\mathbf{0 . 4 7 9}^{* * * *} \\
(0.049)\end{array}$ & $\begin{array}{l}\mathbf{0 . 0 6 9} \text { * } \\
(0.037)\end{array}$ & $\begin{array}{c}\mathbf{0 . 2 7 7} * * * \\
(0.074)\end{array}$ & $\begin{array}{c}-\mathbf{0 . 1 9 9} * * \\
(0.083)\end{array}$ & $\begin{array}{c}\mathbf{0 . 2 7 5} * * * \\
(0.074)\end{array}$ & $\begin{array}{c}-\mathbf{- 0 . 1 9 9}^{* * *} \\
(0.083)\end{array}$ & $\begin{array}{c}\mathbf{0 . 2 7 3} * * * \\
(0.074)\end{array}$ & $\begin{array}{c}-\mathbf{0 . 2 0 1} * \boldsymbol{*} \\
(0.083)\end{array}$ \\
\hline TA w/ procurement & $\begin{array}{l}-0.116 \\
(0.117)\end{array}$ & $\begin{array}{l}-0.092 \\
(0.123)\end{array}$ & & & $\begin{array}{c}\mathbf{0 . 5 0 9} \\
(0.057)\end{array}$ & $\begin{array}{c}\mathbf{0 . 1 3 4 ^ { * * * }} \\
(0.038)\end{array}$ & $\begin{array}{c}\mathbf{0 . 3 6 8} * * * \\
(0.053)\end{array}$ & $\begin{array}{c}\mathbf{0 . 0 9 5} * * \\
(0.043)\end{array}$ & $\begin{array}{c}\mathbf{0 . 3 1 7} * * * \\
(0.052)\end{array}$ & $\begin{array}{c}\mathbf{0 . 0 3 9} \\
(0.045)\end{array}$ \\
\hline WTO GPA & $\begin{array}{c}0.996^{* * *} \\
(0.110)\end{array}$ & $\begin{array}{c}0.753^{* * *} \\
(0.105)\end{array}$ & & & & & $\begin{array}{c}\mathbf{0 . 3 4 2} \text { *** } \\
(0.061)\end{array}$ & $\begin{array}{l}\text { 0.098* } \\
(0.051)\end{array}$ & $\begin{array}{c}\mathbf{0 . 2 3 3} \\
(0.063)\end{array}$ & $\begin{array}{c}\mathbf{0 . 0 0 6} \\
(0.055)\end{array}$ \\
\hline $\mathrm{EU}$ & $\begin{array}{c}0.007 \\
(0.126)\end{array}$ & $\begin{array}{c}0.071 \\
(0.114)\end{array}$ & & & & & & & $\begin{array}{c}\mathbf{0 . 5 9 8} \\
(0.086 *)\end{array}$ & $\begin{array}{c}\mathbf{0 . 3 1 4} \text { *** } \\
(0.065)\end{array}$ \\
\hline Obs & 80,724 & 80,724 & 80,724 & 80,724 & 80,724 & 80,724 & 80,724 & 80,724 & 80,724 & 80,724 \\
\hline
\end{tabular}

Note: All regressions include importer-year and exporter-year fixed effects. Columns (3) to (10) include also country-pair fixed effects. In columns (3) and (4), the TA dummy equals one if the two countries in the pair belong to the same TA (with or without provisions on government procurement). Data are for all years between 1995 and 2015. Coefficients in bold are statistically different between the 'Gov.' and 'Priv.' regressions. Robust standard errors clustered at the country-pair level are in parentheses. Significant at: ${ }^{*} 10 \%, * * 5 \%, * * * 1 \%$ level. 
Table A6: PPML Gravity estimates, Goods, sector-level trade data.

\begin{tabular}{|c|c|c|c|c|c|c|c|c|c|c|}
\hline & $\begin{array}{l}(1) \\
\text { Gov. }\end{array}$ & $\begin{array}{c}(2) \\
\text { Priv. }\end{array}$ & $\begin{array}{l}(3) \\
\text { Gov. }\end{array}$ & $\begin{array}{c}(4) \\
\text { Priv. }\end{array}$ & $\begin{array}{l}(5) \\
\text { Gov. }\end{array}$ & $\begin{array}{c}(6) \\
\text { Priv. }\end{array}$ & $\begin{array}{l}(7) \\
\text { Gov. }\end{array}$ & $\begin{array}{c}(8) \\
\text { Priv. }\end{array}$ & $\begin{array}{l}(9) \\
\text { Gov. }\end{array}$ & $\begin{array}{l}(10) \\
\text { Priv. }\end{array}$ \\
\hline Same country & $\begin{array}{c}3.457^{* * *} \\
(0.153)\end{array}$ & $\begin{array}{c}3.218^{* * *} \\
(0.178)\end{array}$ & & & & & & & & \\
\hline Contiguity & $\begin{array}{c}0.138 \\
(0.120)\end{array}$ & $\begin{array}{l}0.228^{*} \\
(0.125)\end{array}$ & & & & & & & & \\
\hline Common language & $\begin{array}{c}0.412^{* * *} \\
(0.106)\end{array}$ & $\begin{array}{c}0.306^{* * *} \\
(0.105)\end{array}$ & & & & & & & & \\
\hline Colony & $\begin{array}{c}0.370^{* *} \\
(0.162)\end{array}$ & $\begin{array}{l}0.427^{*} \\
(0.222)\end{array}$ & & & & & & & & \\
\hline Ln Distance & $\begin{array}{c}-\mathbf{0 . 7 5 1 * * *} \\
(0.046)\end{array}$ & $\begin{array}{c}-\mathbf{0 . 8 9 5} * * * \\
(0.051)\end{array}$ & & & & & & & & \\
\hline Common legal origin & $\begin{array}{c}0.016 \\
(0.069)\end{array}$ & $\begin{array}{c}0.105 \\
(0.078)\end{array}$ & & & & & & & & \\
\hline $\mathrm{TA}$ & $\begin{array}{l}-0.091 \\
(0.106)\end{array}$ & $\begin{array}{c}0.052 \\
(0.126)\end{array}$ & $\begin{array}{c}\mathbf{0 . 1 4 7 * * *} \\
(0.044)\end{array}$ & $\begin{array}{c}\mathbf{0 . 2 6 5} \text { *** } \\
(0.037)\end{array}$ & $\begin{array}{c}0.263 \\
(0.160)\end{array}$ & $\begin{array}{c}0.270^{* * *} \\
(0.092)\end{array}$ & $\begin{array}{l}0.265^{*} \\
(0.160)\end{array}$ & $\begin{array}{c}0.270^{* * *} \\
(0.092)\end{array}$ & $\begin{array}{c}0.255 \\
(0.160)\end{array}$ & $\begin{array}{c}0.262^{* * *} \\
(0.092)\end{array}$ \\
\hline TA w/ procurement & $\begin{array}{c}0.128 \\
(0.099)\end{array}$ & $\begin{array}{l}0.281^{* *} \\
(0.122)\end{array}$ & & & $\begin{array}{c}\mathbf{0 . 1 3 2} * * * \\
(0.044)\end{array}$ & $\begin{array}{c}\mathbf{0 . 2 6 4} * * * \\
(0.039)\end{array}$ & $\begin{array}{c}0.178^{* * *} \\
(0.050)\end{array}$ & $\begin{array}{c}0.251^{* * *} \\
(0.043)\end{array}$ & $\begin{array}{c}0.105^{* *} \\
(0.050)\end{array}$ & $\begin{array}{c}0.176^{* * *} \\
(0.038)\end{array}$ \\
\hline WTO GPA & $\begin{array}{c}0.698^{* * *} \\
(0.116)\end{array}$ & $\begin{array}{c}0.417^{* * *} \\
(0.126)\end{array}$ & & & & & $\begin{array}{c}-\mathbf{0 . 1 5 7 * *} \\
(0.074)\end{array}$ & $\begin{array}{c}\mathbf{0 . 0 3 5} \\
(0.062)\end{array}$ & $\begin{array}{c}-0.308^{* * *} * \\
(0.082)\end{array}$ & $\begin{array}{l}-0.129^{*} \\
(0.078)\end{array}$ \\
\hline $\mathrm{EU}$ & $\begin{array}{c}0.090 \\
(0.124)\end{array}$ & $\begin{array}{c}0.211^{* *} \\
(0.096)\end{array}$ & & & & & & & $\begin{array}{c}0.582^{* * *} \\
(0.102)\end{array}$ & $\begin{array}{c}0.617^{* * * *} \\
(0.082)\end{array}$ \\
\hline Obs & 230,330 & 230,454 & 230,330 & 230,454 & 230,330 & 230,454 & 230,330 & 230,454 & 230,330 & 230,454 \\
\hline
\end{tabular}

Note: All regressions include importer-sector-year and exporter-sector-year fixed effects. Columns (3) to (10) include also country-pair fixed effects. In columns (3) and (4), the $T A$ dummy equals one if the two countries in the pair belong to the same TA (with or without provisions on government procurement). Data are for the years 1995, 1999, 2003, 2007,2011 and 2015. The dependent variable is at the sector level (Table A1 reports the list of sectors). Coefficients in bold are statistically different between the 'Gov.' and 'Priv.' regressions. Robust standard errors clustered at the country-pair level are in parentheses. Significant at: $* 10 \%, * * 5 \%, * * * 1 \%$ level. 
Table A7: PPML Gravity estimates, Services, sector-level trade data.

\begin{tabular}{|c|c|c|c|c|c|c|c|c|c|c|}
\hline & $\begin{array}{l}(1) \\
\text { Gov. }\end{array}$ & $\begin{array}{c}(2) \\
\text { Priv. }\end{array}$ & $\begin{array}{l}(3) \\
\text { Gov. }\end{array}$ & $\begin{array}{l}(4) \\
\text { Priv. }\end{array}$ & $\begin{array}{l}(5) \\
\text { Gov. }\end{array}$ & $\begin{array}{l}(6) \\
\text { Priv. }\end{array}$ & $\begin{array}{l}(7) \\
\text { Gov. }\end{array}$ & $\begin{array}{l}\text { (8) } \\
\text { Priv. }\end{array}$ & $\begin{array}{l}\text { (9) } \\
\text { Gov. }\end{array}$ & $\begin{array}{l}\text { (10) } \\
\text { Priv. }\end{array}$ \\
\hline Same country & $\begin{array}{c}7.056^{* * *} \\
(0.173)\end{array}$ & $\begin{array}{c}5.802 * * * \\
(0.192)\end{array}$ & & & & & & & & \\
\hline Contiguity & $\begin{array}{c}0.147 \\
(0.108)\end{array}$ & $\begin{array}{c}0.386^{* * * *} \\
(0.127)\end{array}$ & & & & & & & & \\
\hline Common language & $\begin{array}{c}0.639^{* * *} * \\
(0.097)\end{array}$ & $\begin{array}{c}0.584^{* * *} \\
(0.103)\end{array}$ & & & & & & & & \\
\hline Colony & $\begin{array}{c}0.487^{* * *} \\
(0.166)\end{array}$ & $\begin{array}{c}0.741^{* * *} \\
(0.167)\end{array}$ & & & & & & & & \\
\hline Ln Distance & $\begin{array}{c}-0.506^{* * *} \\
(0.051)\end{array}$ & $\begin{array}{c}-0.403^{* * *} \\
(0.056)\end{array}$ & & & & & & & & \\
\hline Common legal origin & $\begin{array}{c}0.094 \\
(0.066)\end{array}$ & $\begin{array}{c}0.077 \\
(0.079)\end{array}$ & & & & & & & & \\
\hline FTA w/out procurement & $\begin{array}{l}0.244^{*} \\
(0.145)\end{array}$ & $\begin{array}{c}0.357^{* *} \\
(0.142)\end{array}$ & $\begin{array}{c}\mathbf{0 . 5 0 8} \\
(0.047 * *\end{array}$ & $\begin{array}{c}\mathbf{0 . 0 9 5} * * \\
(0.038)\end{array}$ & $\begin{array}{c}\mathbf{0 . 2 7 6} \text { *** } \\
(0.070)\end{array}$ & $\begin{array}{c}-\mathbf{- 0 . 1 9 9}^{* *} \\
(0.080)\end{array}$ & $\begin{array}{c}\mathbf{0 . 2 7 4} * * * \\
(0.069)\end{array}$ & $\begin{array}{c}-\mathbf{0 . 1 9 9} * * \\
(0.080)\end{array}$ & $\begin{array}{c}\mathbf{0 . 2 7 0} \text { *** } \\
(0.069)\end{array}$ & $\begin{array}{c}-0.202^{* *} \\
(0.080)\end{array}$ \\
\hline FTA w/ procurement & $\begin{array}{l}-0.126 \\
(0.109)\end{array}$ & $\begin{array}{c}-0.062 \\
(0.120)\end{array}$ & & & $\begin{array}{c}\mathbf{0 . 5 3 9} \\
(0.053)\end{array}$ & $\begin{array}{c}\mathbf{0 . 1 5 7} * * * \\
(0.040)\end{array}$ & $\begin{array}{c}\mathbf{0 . 3 7 2} \\
(0.043 * *\end{array}$ & $\begin{array}{c}\mathbf{0 . 0 9 9} * * \\
(0.041)\end{array}$ & $\begin{array}{c}\mathbf{0 . 3 2 0} \text { **** } \\
(0.042)\end{array}$ & $\begin{array}{c}\mathbf{0 . 0 4 2} \\
(0.042)\end{array}$ \\
\hline WTO GPA & $\begin{array}{c}1.060^{* * *} \\
(0.107)\end{array}$ & $\begin{array}{c}\mathbf{0 . 7 4 2} \text { *** } \\
(0.106)\end{array}$ & & & & & $\begin{array}{c}\mathbf{0 . 4 2 4} * * * \\
(0.050)\end{array}$ & $\begin{array}{c}\mathbf{0 . 1 4 5 * * *} \\
(0.044)\end{array}$ & $\begin{array}{c}\mathbf{0 . 3 2 2} \text { **** } \\
(0.049)\end{array}$ & $\begin{array}{l}\mathbf{0 . 0 5 7} \\
(0.045)\end{array}$ \\
\hline $\mathrm{EU}$ & $\begin{array}{c}0.020 \\
(0.123)\end{array}$ & $\begin{array}{c}0.119 \\
(0.113)\end{array}$ & & & & & & & $\begin{array}{c}\mathbf{0 . 6 1 1} \text { *** } \\
(0.076)\end{array}$ & $\begin{array}{c}\mathbf{0 . 3 3 4 ^ { * * * }} \\
(0.060)\end{array}$ \\
\hline Obs & 184,512 & 184,512 & 184,512 & 184,512 & 184,512 & 184,512 & 184,512 & 184,512 & 184,512 & 184,512 \\
\hline
\end{tabular}

Note: All regressions include importer-secotr-year and exporter-sector-year fixed effects. Columns (3) to (10) include also country-pair fixed effects. In columns (3) and (4), the $T A$ dummy equals one if the two countries in the pair belong to the same TA (with or without provisions on government procurement). Data are for the years 1995, 1999, 2003, 2007, 2011 and 2015. The dependent variable is at the sector level (Table A1 reports the list of sectors). Coefficients in bold are statistically different between the 'Gov.' and 'Priv.' regressions. Robust standard errors clustered at the country-pair level are in parentheses. Significant at: $* 10 \%, * * 5 \%, * * * 1 \%$ level.

\section{Figure A3: Trade effect of single provisions on government procurement - Goods}

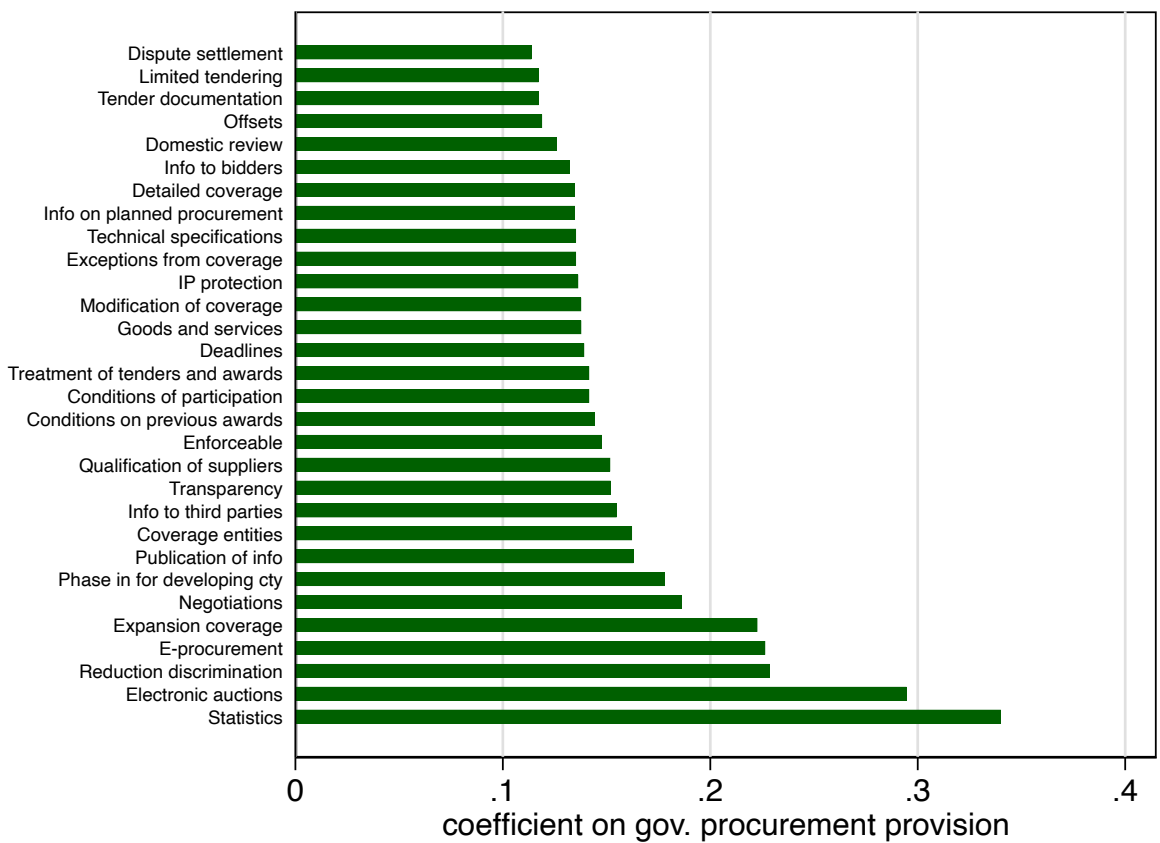

Note: The bars represent estimated coefficient on a dummy for the presence of the indicated provision. The dependent variable of the gravity model is bilateral flows in government procurement. Controls include a dummy for TAs without government procurement, a dummy for TAs with provisions other than the one being 'tested', a dummy for membership in the WTO GPA, and an EU dummy. All regressions include exporter-year, importer-year and country-pair fixed effects. 


\section{Figure A4: Trade effect of single provisions on government procurement - Services}

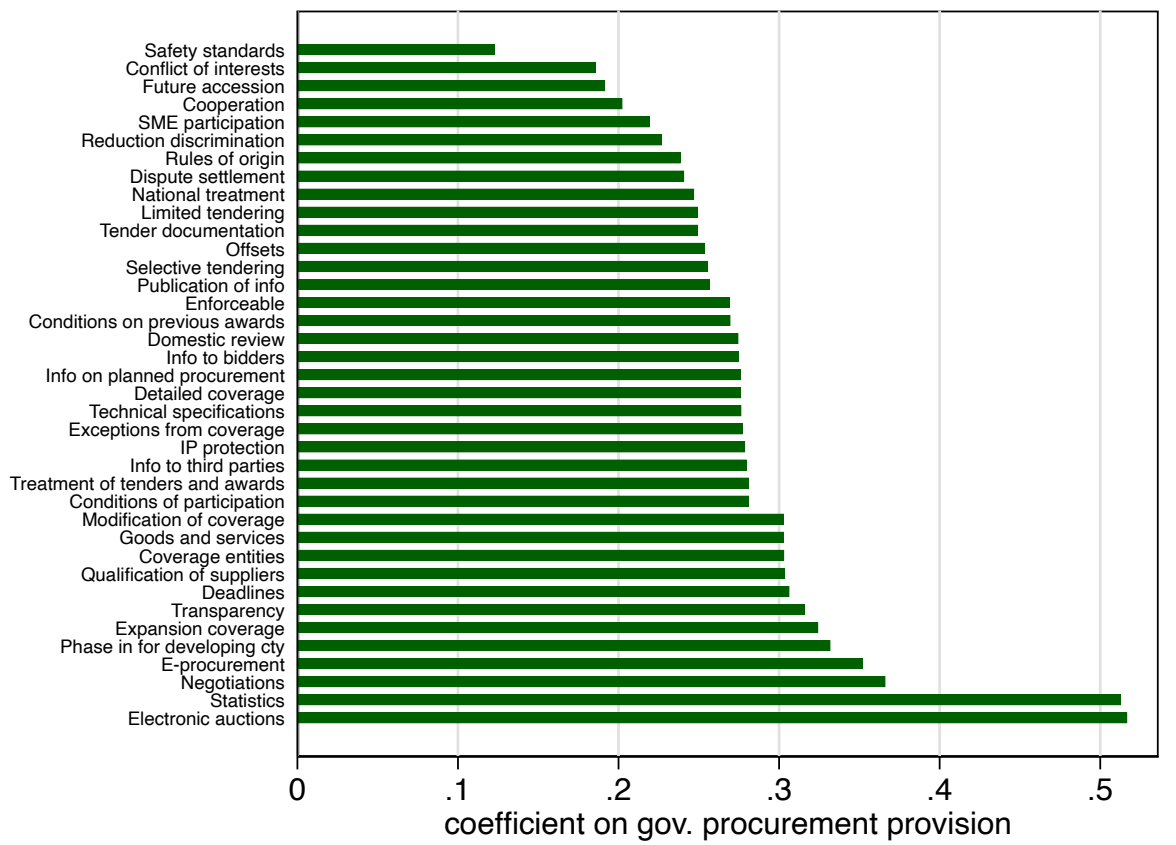

Note: The bars represent estimated coefficient on a dummy for the presence of the indicated provision. The dependent variable of the gravity model is bilateral flows in government procurement. Controls include a dummy for TAs without government procurement, a dummy for TAs with provisions other than the one being 'tested', a dummy for membership in the WTO GPA, and an EU dummy. All regressions include exporter-year, importer-year and country-pair fixed effects. 
Table A8: CHB Indexes - Goods

\begin{tabular}{|c|c|c|c|c|c|c|c|c|c|c|c|c|c|c|c|c|}
\hline & \multicolumn{2}{|c|}{1995} & \multicolumn{2}{|c|}{1999} & \multicolumn{2}{|c|}{2003} & \multicolumn{2}{|c|}{2007} & \multicolumn{2}{|c|}{2011} & \multicolumn{2}{|c|}{2015} & \multicolumn{2}{|c|}{ Avg. } & \multicolumn{2}{|c|}{$15-95 \%$} \\
\hline Cty & Gov & Priv & Gov & Priv & Gov & Priv & Gov & Priv & Gov & Priv & Gov & Priv & Gov & Priv & Gov & Priv \\
\hline$\overline{\mathrm{ARG}}$ & 315 & 108 & 293 & 104 & 387 & 165 & 204 & 127 & 124 & 94 & 81 & 84 & 234 & 114 & $-74 \%$ & $-22 \%$ \\
\hline AUS & 83 & 65 & 83 & 66 & 85 & 65 & 70 & 55 & 59 & 49 & 73 & 64 & 76 & 61 & $-12 \%$ & $-1 \%$ \\
\hline $\mathrm{AUT}$ & 105 & 92 & 118 & 101 & 120 & 95 & 101 & 96 & 116 & 110 & 114 & 136 & 112 & 105 & $9 \%$ & $48 \%$ \\
\hline BEL & 86 & 57 & 92 & 63 & 84 & 62 & 63 & 66 & 72 & 79 & 79 & 104 & 79 & 72 & $-8 \%$ & $82 \%$ \\
\hline BGR & 1089 & 783 & 1151 & 1017 & 953 & 792 & 738 & 535 & 995 & 617 & 1044 & 734 & 995 & 746 & $-4 \%$ & $-6 \%$ \\
\hline BRA & 44 & 32 & 66 & 44 & 75 & 44 & 52 & 32 & 31 & 24 & 43 & 37 & 52 & 35 & $-2 \%$ & $15 \%$ \\
\hline BRN & 5687 & 3954 & 8597 & 4233 & 10690 & 3063 & 2508 & 2026 & 2862 & 1752 & 1940 & 2540 & 5381 & 2928 & $-66 \%$ & $-36 \%$ \\
\hline CAN & 26 & 32 & 24 & 27 & 19 & 26 & 20 & 27 & 24 & 31 & 23 & 34 & 23 & 29 & $-13 \%$ & $6 \%$ \\
\hline CHE & 37 & 65 & 43 & 73 & 42 & 73 & 30 & 79 & 31 & 82 & 29 & 93 & 35 & 78 & $-22 \%$ & $43 \%$ \\
\hline CHL & 622 & 215 & 594 & 258 & 693 & 258 & 434 & 175 & 422 & 172 & 372 & 201 & 523 & 213 & $-40 \%$ & $-7 \%$ \\
\hline $\mathrm{CHN}$ & 23 & 12 & 13 & 9 & 11 & 7 & 8 & 6 & 6 & 4 & 4 & 3 & 11 & 7 & $-84 \%$ & $-77 \%$ \\
\hline $\mathrm{COL}$ & 322 & 214 & 218 & 242 & 336 & 269 & 245 & 199 & 204 & 169 & 230 & 212 & 259 & 218 & $-28 \%$ & $-1 \%$ \\
\hline CRI & 1932 & 1388 & 1363 & 1138 & 1660 & 1271 & 1430 & 1305 & 1268 & 1311 & 1077 & 1287 & 1455 & 1283 & $-44 \%$ & $-7 \%$ \\
\hline CYP & 5553 & 3039 & 3936 & 3336 & 3102 & 3054 & 3184 & 2834 & 4429 & 3812 & 5999 & 6395 & 4367 & 3745 & $8 \%$ & $110 \%$ \\
\hline CZE & 243 & 198 & 295 & 189 & 235 & 147 & 167 & 110 & 172 & 123 & 193 & 152 & 218 & 153 & $-20 \%$ & $-23 \%$ \\
\hline DEU & 11 & 10 & 13 & 11 & 14 & 11 & 11 & 11 & 13 & 14 & 14 & 17 & 13 & 12 & $24 \%$ & $74 \%$ \\
\hline DNK & 150 & 137 & 160 & 150 & 159 & 147 & 101 & 157 & 111 & 201 & 102 & 260 & 131 & 175 & $-32 \%$ & $89 \%$ \\
\hline ESP & 48 & 33 & 53 & 33 & 45 & 29 & 30 & 28 & 38 & 40 & 44 & 51 & 43 & 35 & $-8 \%$ & $55 \%$ \\
\hline $\mathrm{EST}$ & 2630 & 2686 & 2458 & 2426 & 2314 & 1880 & 1701 & 1261 & 1800 & 1445 & 1746 & 1667 & 2108 & 1894 & $-34 \%$ & $-38 \%$ \\
\hline FIN & 138 & 135 & 137 & 137 & 141 & 134 & 95 & 131 & 161 & 167 & 158 & 230 & 138 & 156 & $14 \%$ & $70 \%$ \\
\hline FRA & 14 & 16 & 18 & 17 & 17 & 17 & 17 & 21 & 19 & 26 & 21 & 35 & 18 & 22 & $50 \%$ & $121 \%$ \\
\hline GBR & 15 & 20 & 14 & 19 & 15 & 20 & 16 & 23 & 19 & 33 & 19 & 35 & 16 & 25 & $25 \%$ & $75 \%$ \\
\hline GRC & 220 & 192 & 260 & 214 & 167 & 201 & 145 & 212 & 241 & 294 & 333 & 410 & 228 & 254 & $52 \%$ & $113 \%$ \\
\hline HKG & 799 & 403 & 761 & 546 & 1113 & 772 & 468 & 275 & 520 & 271 & 417 & 240 & 680 & 418 & $-48 \%$ & $-40 \%$ \\
\hline HRV & 556 & 826 & 786 & 926 & 871 & 808 & 713 & 753 & 874 & 1033 & 914 & 1309 & 786 & 942 & $64 \%$ & $58 \%$ \\
\hline HUN & 278 & 242 & 277 & 224 & 220 & 176 & 159 & 138 & 206 & 168 & 209 & 203 & 225 & 192 & $-25 \%$ & $-16 \%$ \\
\hline IDN & 152 & 64 & 153 & 76 & 133 & 70 & 185 & 58 & 156 & 39 & 162 & 44 & 157 & 58 & $6 \%$ & $-31 \%$ \\
\hline IND & 116 & 41 & 83 & 37 & 89 & 33 & 65 & 24 & 50 & 21 & 49 & 21 & 75 & 30 & $-58 \%$ & $-48 \%$ \\
\hline IRL & 89 & 142 & 71 & 114 & 61 & 103 & 50 & 128 & 59 & 185 & 46 & 163 & 63 & 139 & $-48 \%$ & $15 \%$ \\
\hline ISL & 2373 & 2704 & 2280 & 2407 & 2063 & 2378 & 1893 & 2239 & 2556 & 3127 & 2508 & 3445 & 2279 & 2717 & $6 \%$ & $27 \%$ \\
\hline ISR & 156 & 263 & 128 & 256 & 134 & 266 & 133 & 256 & 136 & 259 & 137 & 271 & 138 & 262 & $-12 \%$ & $3 \%$ \\
\hline ITA & 34 & 18 & 34 & 18 & 32 & 17 & 22 & 19 & 32 & 25 & 31 & 33 & 31 & 22 & $-10 \%$ & $80 \%$ \\
\hline JPN & 5 & 5 & 6 & 6 & 7 & 8 & 9 & 10 & 7 & 10 & 10 & 15 & 7 & 9 & $99 \%$ & $185 \%$ \\
\hline KHM & 13947 & 5332 & 12677 & 3470 & 6894 & 2761 & 7429 & 2805 & 6273 & 2283 & 4640 & 1799 & 8643 & 3075 & $-67 \%$ & $-66 \%$ \\
\hline KOR & 43 & 27 & 44 & 29 & 38 & 26 & 28 & 23 & 29 & 22 & 26 & 23 & 35 & 25 & $-38 \%$ & $-14 \%$ \\
\hline LTU & 1886 & 1909 & 1756 & 1642 & 1468 & 1183 & 1247 & 809 & 1223 & 844 & 1395 & 1052 & 1496 & 1240 & $-26 \%$ & $-45 \%$ \\
\hline LUX & 1370 & 775 & 1494 & 817 & 1328 & 775 & 1227 & 823 & 1608 & 1102 & 2015 & 1410 & 1507 & 950 & $47 \%$ & $82 \%$ \\
\hline LVA & 2553 & 3026 & 2955 & 2930 & 2057 & 2163 & 2072 & 1403 & 2588 & 1793 & 2794 & 2095 & 2503 & 2235 & $9 \%$ & $-31 \%$ \\
\hline MAR & 745 & 377 & 1522 & 388 & 1801 & 383 & 497 & 420 & 464 & 407 & 417 & 466 & 908 & 407 & $-44 \%$ & $23 \%$ \\
\hline MEX & 97 & 50 & 66 & 31 & 64 & 32 & 38 & 30 & 43 & 36 & 38 & 39 & 58 & 37 & $-60 \%$ & $-22 \%$ \\
\hline MLT & 2212 & 3247 & 2497 & 3082 & 2726 & 3032 & 1750 & 3008 & 1916 & 3642 & 2101 & 4369 & 2200 & 3397 & $-5 \%$ & $35 \%$ \\
\hline MYS & 145 & 114 & 143 & 96 & 108 & 77 & 115 & 76 & 100 & 68 & 94 & 67 & 118 & 83 & $-35 \%$ & $-42 \%$ \\
\hline NLD & 44 & 47 & 49 & 52 & 45 & 50 & 46 & 52 & 57 & 61 & 64 & 79 & 51 & 57 & $45 \%$ & $68 \%$ \\
\hline NOR & 195 & 132 & 204 & 126 & 194 & 115 & 89 & 104 & 87 & 118 & 107 & 161 & 146 & 126 & $-45 \%$ & $22 \%$ \\
\hline NZL & 621 & 320 & 551 & 360 & 513 & 317 & 349 & 302 & 355 & 329 & 375 & 373 & 461 & 333 & $-40 \%$ & $17 \%$ \\
\hline PER & 577 & 394 & 556 & 407 & 706 & 386 & 653 & 321 & 570 & 254 & 497 & 259 & 593 & 337 & $-14 \%$ & $-34 \%$ \\
\hline PHL & 195 & 159 & 203 & 176 & 307 & 201 & 311 & 183 & 288 & 161 & 186 & 129 & 248 & 168 & $-5 \%$ & $-19 \%$ \\
\hline POL & 143 & 113 & 205 & 112 & 188 & 101 & 96 & 70 & 108 & 76 & 106 & 92 & 141 & 94 & $-26 \%$ & $-18 \%$ \\
\hline PRT & 227 & 146 & 234 & 150 & 220 & 148 & 198 & 167 & 252 & 218 & 310 & 285 & 240 & 186 & $36 \%$ & $96 \%$ \\
\hline $\mathrm{ROU}$ & 431 & 329 & 409 & 412 & 347 & 327 & 318 & 191 & 365 & 231 & 455 & 281 & 388 & 295 & $5 \%$ & $-15 \%$ \\
\hline RUS & 63 & 60 & 116 & 94 & 75 & 58 & 35 & 33 & 34 & 32 & 41 & 39 & 61 & 53 & $-35 \%$ & $-35 \%$ \\
\hline SAU & 210 & 130 & 183 & 121 & 154 & 104 & 121 & 82 & 106 & 72 & 90 & 93 & 144 & 100 & $-57 \%$ & $-29 \%$ \\
\hline SGP & 110 & 127 & 118 & 135 & 116 & 134 & 135 & 130 & 121 & 122 & 120 & 124 & 120 & 129 & $9 \%$ & $-2 \%$ \\
\hline SVK & 530 & 448 & 659 & 467 & 585 & 345 & 333 & 217 & 402 & 239 & 386 & 268 & 482 & 331 & $-27 \%$ & $-40 \%$ \\
\hline SVN & 759 & 650 & 856 & 688 & 828 & 616 & 594 & 502 & 680 & 638 & 673 & 787 & 732 & 647 & $-11 \%$ & $21 \%$ \\
\hline SWE & 72 & 78 & 73 & 77 & 75 & 76 & 59 & 80 & 66 & 99 & 83 & 133 & 72 & 90 & $15 \%$ & $71 \%$ \\
\hline TUN & 1656 & 686 & 1431 & 626 & 1780 & 642 & 758 & 774 & 628 & 850 & 606 & 909 & 1143 & 748 & $-63 \%$ & $33 \%$ \\
\hline TUR & 107 & 81 & 103 & 85 & 137 & 64 & 174 & 60 & 194 & 64 & 160 & 65 & 146 & 70 & $49 \%$ & $-20 \%$ \\
\hline TWN & 48 & 46 & 59 & 48 & 74 & 48 & 83 & 50 & 78 & 48 & 79 & 54 & 70 & 49 & $65 \%$ & $17 \%$ \\
\hline USA & 3 & 4 & 2 & 4 & 2 & 4 & 3 & 5 & 3 & 6 & 4 & 6 & 3 & 5 & $48 \%$ & $31 \%$ \\
\hline VNM & 748 & 394 & 653 & 295 & 558 & 229 & 374 & 169 & 267 & 123 & 172 & 83 & 462 & 215 & $-77 \%$ & $-79 \%$ \\
\hline $\mathrm{ZAF}$ & 147 & 129 & 188 & 140 & 145 & 119 & 156 & 115 & 150 & 119 & 212 & 171 & 166 & 132 & $44 \%$ & $33 \%$ \\
\hline
\end{tabular}

Note: Constructed Home Bias indexes estimated from the specifications in columns (7) and (8), Table 3. 
Table A9: CHB Indexes - Services

\begin{tabular}{|c|c|c|c|c|c|c|c|c|c|c|c|c|c|c|c|c|}
\hline & \multicolumn{2}{|c|}{1995} & \multicolumn{2}{|c|}{1999} & \multicolumn{2}{|c|}{2003} & \multicolumn{2}{|c|}{2007} & \multicolumn{2}{|c|}{2011} & \multicolumn{2}{|c|}{2015} & \multicolumn{2}{|c|}{ Avg. } & \multicolumn{2}{|c|}{ 15-95\% } \\
\hline Cty & Gov & Priv & Gov & Priv & Gov & Priv & Gov & Priv & Gov & Priv & Gov & Priv & Gov & Priv & Gov & Priv \\
\hline ARG & 143 & 108 & 134 & 108 & 431 & 320 & 272 & 244 & 171 & 167 & 125 & 148 & 213 & 182 & $-12 \%$ & $37 \%$ \\
\hline AUS & 69 & 55 & 68 & 55 & 67 & 51 & 56 & 47 & 42 & 35 & 45 & 39 & 58 & 47 & $-35 \%$ & $-29 \%$ \\
\hline AUT & 105 & 118 & 125 & 139 & 136 & 130 & 130 & 122 & 142 & 126 & 156 & 149 & 132 & 131 & $49 \%$ & $26 \%$ \\
\hline BEL & 82 & 74 & 94 & 84 & 92 & 83 & 89 & 82 & 95 & 84 & 104 & 102 & 92 & 85 & $27 \%$ & $38 \%$ \\
\hline BGR & 2618 & 1759 & 2273 & 2246 & 1636 & 1625 & 1216 & 893 & 1323 & 872 & 1429 & 996 & 1749 & 1399 & $-45 \%$ & $-43 \%$ \\
\hline BRA & 27 & 46 & 40 & 59 & 57 & 78 & 34 & 42 & 25 & 29 & 33 & 40 & 36 & 49 & $21 \%$ & $-13 \%$ \\
\hline BRN & 3780 & 8678 & 3833 & 14555 & 4158 & 15485 & 3549 & 11235 & 3932 & 9421 & 4881 & 14954 & 4022 & 12388 & $29 \%$ & $72 \%$ \\
\hline CAN & 36 & 50 & 36 & 47 & 35 & 43 & 31 & 37 & 29 & 37 & 35 & 43 & 34 & 43 & $-1 \%$ & $-14 \%$ \\
\hline CHE & 112 & 69 & 142 & 86 & 139 & 83 & 135 & 82 & 112 & 68 & 108 & 71 & 125 & 77 & $-3 \%$ & $2 \%$ \\
\hline CHL & 689 & 367 & 574 & 390 & 712 & 422 & 486 & 323 & 371 & 247 & 350 & 255 & 531 & 334 & $-49 \%$ & $-31 \%$ \\
\hline CHN & 57 & 59 & 29 & 34 & 27 & 26 & 22 & 22 & 13 & 14 & 8 & 8 & 26 & 27 & $-85 \%$ & $-87 \%$ \\
\hline $\mathrm{COL}$ & 310 & 268 & 228 & 324 & 407 & 415 & 282 & 305 & 219 & 233 & 210 & 262 & 276 & 301 & $-32 \%$ & $-2 \%$ \\
\hline CRI & 3192 & 2513 & 2710 & 2322 & 2675 & 2213 & 3174 & 2150 & 1853 & 1577 & 1327 & 1249 & 2488 & 2004 & $-58 \%$ & $-50 \%$ \\
\hline CYP & 3808 & 2953 & 2937 & 3044 & 2488 & 2623 & 2102 & 1520 & 2086 & 1542 & 3503 & 1996 & 2821 & 2280 & $-8 \%$ & $-32 \%$ \\
\hline CZE & 443 & 367 & 427 & 377 & 320 & 278 & 253 & 212 & 263 & 205 & 341 & 278 & 341 & 286 & $-23 \%$ & $-24 \%$ \\
\hline DEU & 11 & 11 & 13 & 14 & 15 & 15 & 16 & 15 & 17 & 16 & 18 & 19 & 15 & 15 & $70 \%$ & $67 \%$ \\
\hline DNK & 110 & 146 & 117 & 163 & 119 & 155 & 124 & 138 & 135 & 151 & 158 & 177 & 127 & 155 & $44 \%$ & $21 \%$ \\
\hline ESP & 48 & 43 & 51 & 47 & 45 & 37 & 38 & 30 & 41 & 38 & 53 & 49 & 46 & 41 & $11 \%$ & $14 \%$ \\
\hline EST & 4935 & 6030 & 3963 & 3968 & 3472 & 2858 & 2325 & 1871 & 2536 & 2134 & 2454 & 2326 & 3281 & 3198 & $-50 \%$ & $-61 \%$ \\
\hline FIN & 170 & 229 & 189 & 249 & 183 & 222 & 179 & 214 & 176 & 221 & 200 & 264 & 183 & 233 & $18 \%$ & $16 \%$ \\
\hline FRA & 14 & 18 & 16 & 21 & 16 & 19 & 17 & 18 & 19 & 20 & 22 & 24 & 17 & 20 & $55 \%$ & $31 \%$ \\
\hline GBR & 20 & 20 & 17 & 16 & 15 & 15 & 14 & 14 & 20 & 20 & 19 & 19 & 18 & 17 & $-5 \%$ & $-9 \%$ \\
\hline GRC & 237 & 206 & 235 & 222 & 192 & 195 & 153 & 163 & 216 & 213 & 322 & 318 & 226 & 220 & $36 \%$ & $55 \%$ \\
\hline HKG & 393 & 126 & 281 & 121 & 330 & 141 & 380 & 156 & 411 & 167 & 319 & 170 & 352 & 147 & $-19 \%$ & $34 \%$ \\
\hline HRV & 882 & 1403 & 1021 & 1558 & 1102 & 1174 & 872 & 907 & 981 & 1076 & 1189 & 1389 & 1008 & 1251 & $35 \%$ & $-1 \%$ \\
\hline HUN & 495 & 602 & 530 & 607 & 372 & 415 & 339 & 346 & 426 & 415 & 506 & 526 & 445 & 485 & $2 \%$ & $-13 \%$ \\
\hline IDN & 283 & 164 & 457 & 243 & 325 & 186 & 234 & 161 & 158 & 105 & 148 & 108 & 267 & 161 & $-48 \%$ & $-35 \%$ \\
\hline IND & 137 & 103 & 98 & 89 & 114 & 77 & 75 & 56 & 60 & 46 & 51 & 38 & 89 & 68 & $-63 \%$ & $-63 \%$ \\
\hline IRL & 340 & 246 & 295 & 194 & 211 & 148 & 189 & 108 & 236 & 151 & 305 & 142 & 263 & 165 & $-10 \%$ & $-42 \%$ \\
\hline ISL & 2804 & 4284 & 2249 & 3525 & 1937 & 3017 & 1600 & 2081 & 2840 & 3753 & 2495 & 3437 & 2321 & 3350 & $-11 \%$ & $-20 \%$ \\
\hline ISR & 175 & 309 & 160 & 292 & 183 & 309 & 228 & 318 & 196 & 262 & 170 & 241 & 185 & 289 & $-3 \%$ & $-22 \%$ \\
\hline ITA & 25 & 23 & 25 & 23 & 23 & 21 & 23 & 20 & 28 & 24 & 35 & 30 & 27 & 23 & $39 \%$ & $30 \%$ \\
\hline JPN & 6 & 5 & 7 & 7 & 8 & 8 & 12 & 11 & 10 & 10 & 14 & 14 & 10 & 9 & $131 \%$ & $182 \%$ \\
\hline KHM & 30961 & 9879 & 28426 & 10579 & 17122 & 9184 & 22783 & 9029 & 17959 & 7517 & 12991 & 5652 & 21707 & 8640 & $-58 \%$ & $-43 \%$ \\
\hline KOR & 85 & 56 & 95 & 66 & 79 & 57 & 57 & 49 & 66 & 52 & 55 & 49 & 73 & 55 & $-36 \%$ & $-13 \%$ \\
\hline LTU & 2991 & 3985 & 2092 & 3116 & 1867 & 2081 & 1339 & 1348 & 1480 & 1512 & 1564 & 1585 & 1889 & 2271 & $-48 \%$ & $-60 \%$ \\
\hline LUX & 1317 & 376 & 1274 & 317 & 1147 & 291 & 917 & 204 & 932 & 208 & 913 & 188 & 1084 & 264 & $-31 \%$ & $-50 \%$ \\
\hline LVA & 3833 & 4461 & 3028 & 3105 & 2616 & 2314 & 1677 & 1271 & 2145 & 1513 & 2235 & 1728 & 2589 & 2398 & $-42 \%$ & $-61 \%$ \\
\hline MAR & 706 & 993 & 705 & 1161 & 739 & 1159 & 689 & 941 & 665 & 912 & 649 & 968 & 692 & 1022 & $-8 \%$ & $-3 \%$ \\
\hline MEX & 160 & 97 & 97 & 68 & 84 & 60 & 98 & 61 & 98 & 66 & 95 & 69 & 105 & 70 & $-41 \%$ & $-29 \%$ \\
\hline MLT & 6891 & 4935 & 6910 & 4513 & 6399 & 4334 & 4961 & 2279 & 4026 & 2000 & 3729 & 1961 & 5486 & 3337 & $-46 \%$ & $-60 \%$ \\
\hline MYS & 397 & 271 & 509 & 315 & 396 & 279 & 385 & 266 & 318 & 213 & 317 & 214 & 387 & 260 & $-20 \%$ & $-21 \%$ \\
\hline NLD & 50 & 57 & 56 & 59 & 50 & 55 & 45 & 55 & 49 & 59 & 59 & 71 & 52 & 59 & $16 \%$ & $26 \%$ \\
\hline NOR & 157 & 192 & 154 & 189 & 132 & 171 & 134 & 149 & 127 & 147 & 143 & 182 & 141 & 171 & $-9 \%$ & $-5 \%$ \\
\hline NZL & 429 & 351 & 439 & 392 & 421 & 344 & 365 & 324 & 355 & 321 & 346 & 311 & 392 & 340 & $-19 \%$ & $-11 \%$ \\
\hline PER & 916 & 575 & 872 & 648 & 955 & 652 & 820 & 639 & 591 & 445 & 448 & 406 & 767 & 561 & $-51 \%$ & $-29 \%$ \\
\hline PHL & 506 & 411 & 478 & 375 & 670 & 432 & 682 & 399 & 557 & 316 & 393 & 253 & 548 & 364 & $-22 \%$ & $-39 \%$ \\
\hline POL & 207 & 199 & 190 & 160 & 183 & 139 & 125 & 104 & 130 & 103 & 141 & 120 & 163 & 137 & $-32 \%$ & $-40 \%$ \\
\hline PRT & 242 & 224 & 225 & 225 & 206 & 207 & 199 & 196 & 243 & 227 & 330 & 301 & 241 & 230 & $36 \%$ & $35 \%$ \\
\hline $\mathrm{ROU}$ & 1173 & 804 & 938 & 817 & 656 & 616 & 354 & 319 & 447 & 302 & 472 & 315 & 673 & 529 & $-60 \%$ & $-61 \%$ \\
\hline RUS & 79 & 108 & 164 & 180 & 80 & 94 & 41 & 45 & 35 & 36 & 48 & 46 & 74 & 85 & $-39 \%$ & $-58 \%$ \\
\hline SAU & 138 & 271 & 121 & 282 & 124 & 300 & 124 & 331 & 94 & 225 & 69 & 183 & 112 & 265 & $-50 \%$ & $-32 \%$ \\
\hline SGP & 415 & 152 & 429 & 159 & 442 & 164 & 336 & 144 & 311 & 114 & 266 & 107 & 366 & 140 & $-36 \%$ & $-30 \%$ \\
\hline SVK & 1218 & 1140 & 1284 & 1088 & 1026 & 816 & 753 & 581 & 670 & 491 & 720 & 567 & 945 & 781 & $-41 \%$ & $-50 \%$ \\
\hline SVN & 1283 & 1274 & 1308 & 1321 & 1244 & 1205 & 1098 & 983 & 1119 & 1083 & 1461 & 1370 & 1252 & 1206 & $14 \%$ & $8 \%$ \\
\hline SWE & 71 & 105 & 73 & 110 & 77 & 110 & 80 & 105 & 84 & 105 & 90 & 123 & 79 & 110 & $26 \%$ & $18 \%$ \\
\hline TUN & 1705 & 2065 & 1486 & 1727 & 1564 & 1651 & 1124 & 1571 & 1292 & 1565 & 1309 & 1771 & 1413 & 1725 & $-23 \%$ & $-14 \%$ \\
\hline TUR & 271 & 128 & 169 & 118 & 174 & 126 & 176 & 76 & 191 & 75 & 182 & 75 & 194 & 100 & $-33 \%$ & $-42 \%$ \\
\hline TWN & 125 & 98 & 121 & 96 & 155 & 110 & 149 & 126 & 155 & 125 & 151 & 128 & 143 & 114 & $21 \%$ & $31 \%$ \\
\hline USA & 4 & 3 & 3 & 3 & 3 & 3 & 3 & 3 & 4 & 4 & 3 & 3 & 3 & 3 & $-10 \%$ & $-5 \%$ \\
\hline VNM & 2840 & 1353 & 2600 & 1187 & 2632 & 1123 & 2007 & 826 & 1392 & 569 & 871 & 371 & 2057 & 905 & $-69 \%$ & $-73 \%$ \\
\hline ZAF & 184 & 190 & 207 & 212 & 194 & 187 & 157 & 170 & 130 & 147 & 166 & 195 & 173 & 184 & $-9 \%$ & $3 \%$ \\
\hline
\end{tabular}

Note: Constructed Home Bias indexes estimated from the specifications in columns (7) and (8), Table 4. 
Table A10: Aggregated CHB Indexes

\begin{tabular}{|c|c|c|c|c|c|c|c|c|c|c|c|c|c|c|c|c|}
\hline & \multicolumn{2}{|c|}{21995} & \multicolumn{2}{|c|}{$\begin{array}{l}1999 \\
\end{array}$} & \multicolumn{2}{|c|}{2003} & \multicolumn{2}{|c|}{2007} & \multicolumn{2}{|c|}{2011} & \multicolumn{2}{|c|}{2015} & \multicolumn{2}{|c|}{ Avg. } & \multicolumn{2}{|c|}{$\bar{~} 15-95 \%$} \\
\hline Cty & Gov & Priv & Gov & Priv & Gov & Priv & Gov & Priv & Gov & Priv & Gov & Priv & Gov & Priv & Gov & Priv \\
\hline ARG & 143 & 108 & 134 & 107 & 431 & 235 & 270 & 179 & 169 & 125 & 124 & 111 & 212 & 144 & $-13 \%$ & $3 \%$ \\
\hline AUS & 70 & 57 & 69 & 57 & 67 & 53 & 56 & 48 & 42 & 37 & 45 & 41 & 58 & 49 & $-35 \%$ & $-28 \%$ \\
\hline AUT & 104 & 110 & 125 & 130 & 136 & 122 & 129 & 117 & 142 & 123 & 156 & 147 & 132 & 125 & $50 \%$ & $34 \%$ \\
\hline BEL & 80 & 68 & 94 & 79 & 92 & 78 & 89 & 79 & 95 & 83 & 104 & 103 & 92 & 82 & $29 \%$ & $50 \%$ \\
\hline BGR & 2573 & 1150 & 2253 & 1575 & 1626 & 1218 & 1208 & 769 & 1320 & 791 & 1425 & 918 & 1734 & 1070 & $-45 \%$ & $-20 \%$ \\
\hline BRA & 27 & 39 & 40 & 53 & 57 & 61 & 34 & 38 & 25 & 27 & 33 & 39 & 36 & 43 & $21 \%$ & $-1 \%$ \\
\hline BRN & 3782 & 5980 & 3836 & 7142 & 4161 & 5231 & 3524 & 3136 & 3909 & 2717 & 4682 & 3602 & 3982 & 4635 & $24 \%$ & $-40 \%$ \\
\hline CAN & 36 & 43 & 36 & 40 & 34 & 37 & 31 & 34 & 29 & 35 & 35 & 41 & 33 & 38 & $-1 \%$ & $-5 \%$ \\
\hline CHE & 108 & 68 & 141 & 84 & 138 & 82 & 130 & 82 & 109 & 70 & 105 & 73 & 122 & 76 & $-3 \%$ & $8 \%$ \\
\hline CHL & 689 & 294 & 575 & 344 & 712 & 365 & 485 & 260 & 372 & 222 & 350 & 240 & 530 & 288 & $-49 \%$ & $-18 \%$ \\
\hline CHN & 56 & 16 & 29 & 13 & 26 & 11 & 21 & 9 & 13 & 6 & 8 & 4 & 25 & 10 & $-86 \%$ & $-76 \%$ \\
\hline $\mathrm{COL}$ & 310 & 248 & 228 & 295 & 407 & 359 & 282 & 262 & 219 & 207 & 210 & 245 & 276 & 269 & $-32 \%$ & $-1 \%$ \\
\hline CRI & 3179 & 1930 & 2689 & 1698 & 2666 & 1820 & 3126 & 1831 & 1844 & 1502 & 1324 & 1256 & 2471 & 1673 & $-58 \%$ & $-35 \%$ \\
\hline CYP & 3809 & 2977 & 2936 & 3108 & 2487 & 2705 & 2106 & 1620 & 2090 & 1661 & 3510 & 2131 & 2823 & 2367 & $-8 \%$ & $-28 \%$ \\
\hline CZE & 440 & 289 & 425 & 290 & 319 & 221 & 252 & 173 & 262 & 176 & 339 & 229 & 340 & 230 & $-23 \%$ & $-21 \%$ \\
\hline DEU & 11 & 11 & 13 & 13 & 15 & 14 & 16 & 14 & 17 & 15 & 18 & 18 & 15 & 14 & $71 \%$ & $72 \%$ \\
\hline DNK & 109 & 143 & 117 & 161 & 119 & 154 & 124 & 141 & 135 & 157 & 158 & 185 & 127 & 157 & $45 \%$ & $30 \%$ \\
\hline ESP & 48 & 39 & 51 & 42 & 45 & 35 & 38 & 29 & 41 & 39 & 53 & 49 & 46 & 39 & $11 \%$ & $27 \%$ \\
\hline EST & 4909 & 4180 & 3948 & 3432 & 3462 & 2555 & 2322 & 1720 & 2532 & 1932 & 2449 & 2144 & 3270 & 2660 & $-50 \%$ & $-49 \%$ \\
\hline FIN & 168 & 183 & 189 & 199 & 183 & 190 & 176 & 183 & 176 & 205 & 200 & 257 & 182 & 203 & $19 \%$ & $40 \%$ \\
\hline FRA & 14 & 17 & 16 & 20 & 16 & 19 & 17 & 18 & 19 & 20 & 22 & 25 & 17 & 20 & $56 \%$ & $44 \%$ \\
\hline GBR & 20 & 20 & 17 & 16 & 15 & 16 & 14 & 15 & 20 & 21 & 19 & 20 & 18 & 18 & $-4 \%$ & $-3 \%$ \\
\hline GRC & 235 & 201 & 236 & 221 & 192 & 196 & 153 & 169 & 216 & 225 & 322 & 333 & 226 & 224 & $37 \%$ & $66 \%$ \\
\hline HKG & 392 & 136 & 281 & 127 & 331 & 145 & 381 & 167 & 412 & 180 & 319 & 181 & 353 & 156 & $-18 \%$ & $33 \%$ \\
\hline HRV & 876 & 1082 & 1018 & 1248 & 1100 & 1036 & 869 & 860 & 979 & 1063 & 1185 & 1369 & 1004 & 1110 & $35 \%$ & $26 \%$ \\
\hline HUN & 492 & 398 & 526 & 383 & 370 & 295 & 335 & 254 & 422 & 298 & 498 & 366 & 441 & 332 & $1 \%$ & $-8 \%$ \\
\hline IDN & 279 & 88 & 437 & 111 & 316 & 105 & 233 & 87 & 158 & 57 & 148 & 63 & 262 & 85 & $-47 \%$ & $-29 \%$ \\
\hline IND & 136 & 56 & 98 & 52 & 114 & 48 & 75 & 35 & 60 & 29 & 51 & 28 & 89 & 41 & $-63 \%$ & $-49 \%$ \\
\hline IRL & 321 & 190 & 291 & 159 & 209 & 134 & 183 & 111 & 230 & 156 & 279 & 146 & 252 & 149 & $-13 \%$ & $-23 \%$ \\
\hline ISL & 2791 & 3595 & 2241 & 3120 & 1939 & 2874 & 1603 & 2109 & 2842 & 3609 & 2498 & 3449 & 2319 & 3126 & $-10 \%$ & $-4 \%$ \\
\hline ISR & 173 & 292 & 159 & 283 & 183 & 299 & 226 & 302 & 195 & 262 & 170 & 247 & 184 & 281 & $-2 \%$ & $-16 \%$ \\
\hline ITA & 25 & 21 & 25 & 21 & 23 & 20 & 23 & 20 & 28 & 24 & 35 & 31 & 27 & 23 & $39 \%$ & $45 \%$ \\
\hline JPN & 6 & 5 & 7 & 7 & 8 & 8 & 12 & 11 & 10 & 10 & 14 & 15 & 10 & 9 & $130 \%$ & $183 \%$ \\
\hline KHM & 30812 & 7136 & 28153 & 5025 & 16829 & 4074 & 21967 & 4252 & 17403 & 3315 & 12585 & 2629 & 21291 & 4405 & $-59 \%$ & $-63 \%$ \\
\hline $\mathrm{KOR}$ & 84 & 38 & 93 & 44 & 78 & 39 & 56 & 34 & 64 & 33 & 54 & 34 & 72 & 37 & $-36 \%$ & $-9 \%$ \\
\hline LTU & 2974 & 2820 & 2089 & 2417 & 1862 & 1701 & 1338 & 1155 & 1478 & 1205 & 1562 & 1393 & 1884 & 1782 & $-47 \%$ & $-51 \%$ \\
\hline LUX & 1231 & 411 & 1284 & 347 & 1156 & 315 & 923 & 214 & 939 & 217 & 919 & 192 & 1075 & 283 & $-25 \%$ & $-53 \%$ \\
\hline LVA & 3815 & 3866 & 3026 & 3062 & 2610 & 2280 & 1679 & 1290 & 2147 & 1553 & 2238 & 1779 & 2586 & 2305 & $-41 \%$ & $-54 \%$ \\
\hline MAR & 706 & 527 & 706 & 571 & 740 & 588 & 685 & 632 & 660 & 585 & 643 & 659 & 690 & 594 & $-9 \%$ & $25 \%$ \\
\hline MEX & 160 & 74 & 97 & 48 & 84 & 48 & 95 & 46 & 96 & 51 & 92 & 55 & 104 & 54 & $-43 \%$ & $-25 \%$ \\
\hline MLT & 6779 & 4058 & 6838 & 3869 & 6359 & 3806 & 4890 & 2350 & 3992 & 2082 & 3714 & 2026 & 5429 & 3032 & $-45 \%$ & $-50 \%$ \\
\hline MYS & 390 & 173 & 496 & 151 & 381 & 122 & 370 & 122 & 304 & 106 & 302 & 104 & 374 & 130 & $-23 \%$ & $-40 \%$ \\
\hline NLD & 50 & 53 & 57 & 57 & 50 & 54 & 45 & 55 & 49 & 59 & 59 & 72 & 52 & 59 & $18 \%$ & $36 \%$ \\
\hline NOR & 155 & 171 & 154 & 171 & 133 & 156 & 133 & 137 & 126 & 140 & 142 & 178 & 141 & 159 & $-8 \%$ & $4 \%$ \\
\hline NZL & 429 & 341 & 439 & 383 & 421 & 337 & 364 & 318 & 355 & 323 & 347 & 322 & 393 & 337 & $-19 \%$ & $-5 \%$ \\
\hline PER & 909 & 494 & 867 & 544 & 952 & 53 & 817 & 471 & 591 & 348 & 449 & 339 & 764 & 455 & $-51 \%$ & $-31 \%$ \\
\hline PHL & 491 & 219 & 468 & 250 & 660 & 293 & 668 & 267 & 548 & 223 & 384 & 178 & 536 & 238 & $-22 \%$ & $-19 \%$ \\
\hline POL & 207 & 153 & 190 & 142 & 183 & 126 & 124 & 93 & 130 & 93 & 140 & 111 & 162 & 120 & $-32 \%$ & $-28 \%$ \\
\hline PRT & 240 & 190 & 226 & 200 & 206 & 19 & 199 & 190 & 243 & 225 & 330 & 298 & 241 & 216 & $37 \%$ & $57 \%$ \\
\hline ROU & 1131 & 462 & 918 & 590 & 648 & 468 & 354 & 262 & 446 & 276 & 472 & 305 & 661 & 394 & $-58 \%$ & $-34 \%$ \\
\hline RUS & 79 & 83 & 163 & 141 & 80 & 80 & 41 & 41 & 35 & 35 & 48 & 44 & 74 & 70 & $-39 \%$ & $-47 \%$ \\
\hline SAU & 138 & 210 & 121 & 211 & 125 & 199 & 124 & 157 & 94 & 130 & 69 & 143 & 112 & 175 & $-50 \%$ & $-32 \%$ \\
\hline SGP & 390 & 142 & 409 & 153 & 420 & 157 & 329 & 142 & 304 & 116 & 262 & 109 & 352 & 136 & $-33 \%$ & $-23 \%$ \\
\hline SVK & 1205 & 775 & 1277 & 826 & 1022 & 609 & 744 & 422 & 667 & 402 & 716 & 451 & 938 & 581 & $-41 \%$ & $-42 \%$ \\
\hline SVN & 1277 & 977 & 1303 & 1060 & 1240 & 969 & 1091 & 833 & 1114 & 960 & 1443 & 1205 & 1245 & 1001 & $13 \%$ & $23 \%$ \\
\hline SWE & 70 & 95 & 73 & 100 & 77 & 101 & 79 & 99 & 84 & 104 & 90 & 125 & 79 & 104 & $28 \%$ & $31 \%$ \\
\hline TUN & 1705 & 997 & 1486 & 984 & 1565 & 1034 & 1116 & 1179 & 1263 & 1209 & 1274 & 1303 & 1401 & 1118 & $-25 \%$ & $31 \%$ \\
\hline TUR & 262 & 104 & 168 & 106 & 174 & 93 & 176 & 71 & 191 & 71 & 182 & 72 & 192 & 86 & $-31 \%$ & $-31 \%$ \\
\hline TWN & 121 & 67 & 120 & 72 & 153 & 76 & 147 & 81 & 153 & 76 & 150 & 87 & 141 & 76 & $23 \%$ & $29 \%$ \\
\hline USA & 4 & 4 & 3 & 3 & 3 & 3 & 3 & 4 & 4 & 4 & 3 & 4 & 3 & 3 & $-9 \%$ & $-3 \%$ \\
\hline VNM & 2808 & 628 & 2556 & 475 & 2557 & 357 & 1858 & 261 & 1288 & 179 & 787 & 119 & 1975 & 337 & $-72 \%$ & $-81 \%$ \\
\hline $\mathrm{ZAF}$ & 183 & 162 & 207 & 182 & 193 & 160 & 157 & 149 & 131 & 138 & 167 & 188 & 173 & 163 & $-9 \%$ & $16 \%$ \\
\hline
\end{tabular}

Note: Constructed Home Bias indexes estimated from the specifications in columns (7) and (8), Tables 3 and 4 . Aggregated CHBs equal a weighted average of sector-level CHBs from Tables A2 and A3, where the weights equal the product of expenditure and sales (as shares). 